\title{
تقويم كتب الرياضيات المطورة بالمرحلة الابتدائية فى ضوي منظومة مهارات القرن الحادي والعشرين (دراسة تحليلية)
}

\author{
/ أيمن مصطظفىمصطفى عبد القادر \\ أستاذ المناهج وتعليم الرياضيات المساعد \\ كلية التربية--جامعة الاسكندرية
}

\begin{abstract}
الملخص

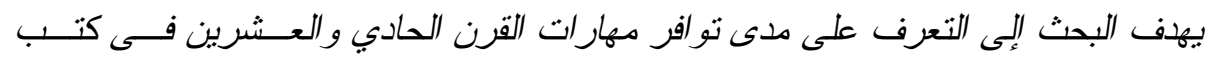

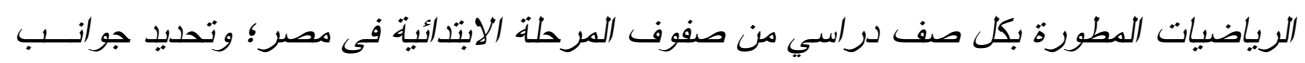

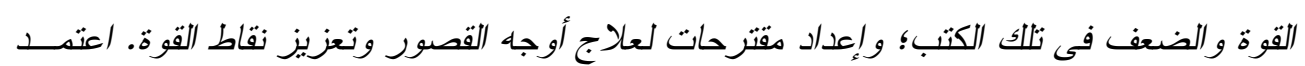

البحث على المنهج الوصفي التحليلي متمثلا فى أسلوب تحليل المحتوى؛ وتكوّنت عبنة البحث من

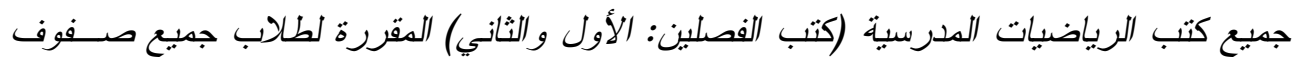

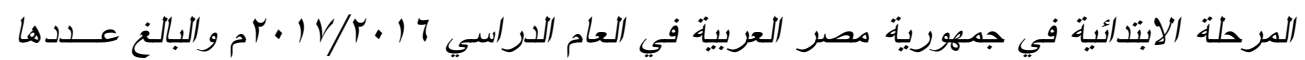

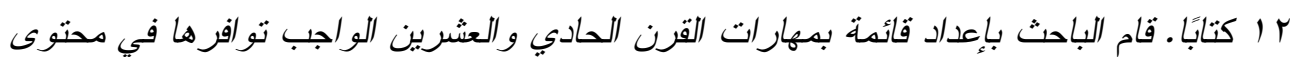

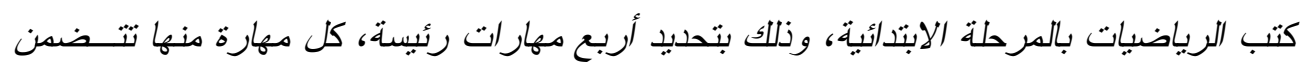

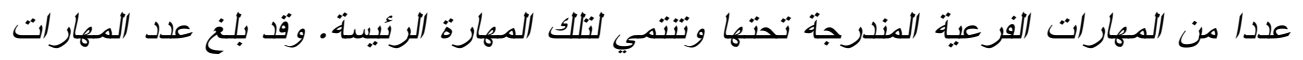

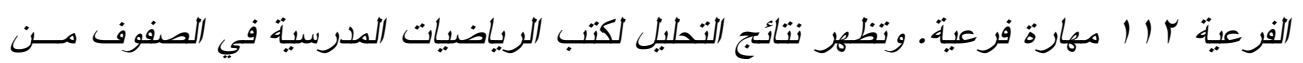

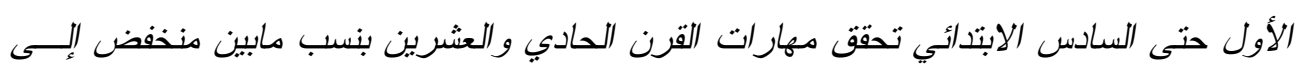

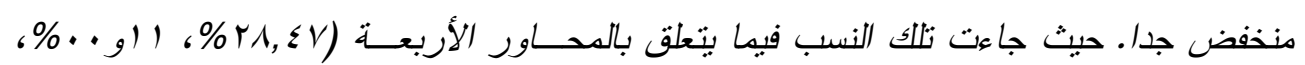

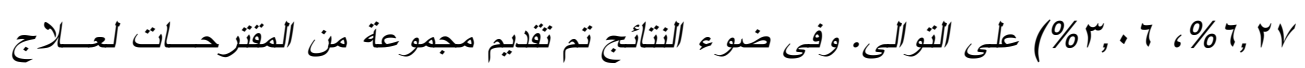

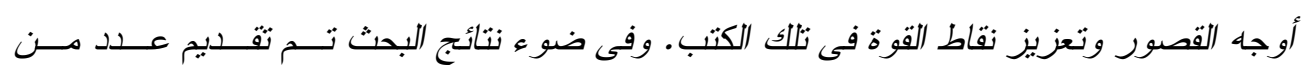

$$
\text { التوصيات و البحوث المقترحة. }
$$
\end{abstract}

\section{Abstract}

The aim of the research is to identify the availability of $21^{\text {st }}$ century skills in the mathematics books developed in each grade of the primary grades in Egypt; to identify the strengths and weaknesses of these books; and to prepare proposals to remedy weaknesses and reinforce points of strengths. The research used analytical descriptive method through the method of content analysis; the research sample consisted of all school 
mathematics textbooks (the first and second semesters), which are scheduled for students of all grades of the primary stage in Egypt in the academic year 2016/2017. The number of books was 12 books. The researcher prepared a list of the skills of $21^{\text {st }}$ century skills which should be available in the content of mathematics textbooks at the primary level by identifying four main skills, each skill which includes a number of sub-skills which belong to that skill key. The number of sub-skills was 112 sub-skills. The results of the analysis of school mathematics textbooks in grades 1 through 6 show the skills of the $21^{\text {st }}$ century in low to very low proportions. The statistics for the four main skills were $28.47 \%, 11 \%, 6.27 \%$ and $3.06 \%$, respectively. Considering the results, a number of proposals were presented to address the weaknesses and reinforce the strengths of these books. In light of the results of the research, a number of recommendations and proposed research were presented.

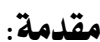

ويوضح بايبي (Bybee, 2010) أن

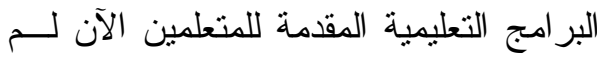

تعد كافية لإعدادهم للحياة و العمل في القــرن

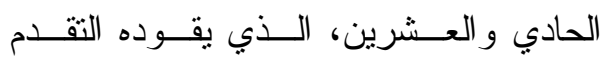

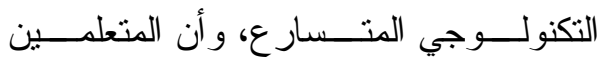

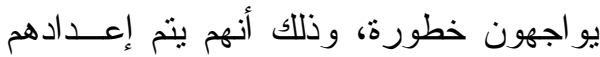

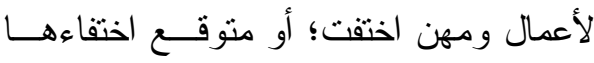

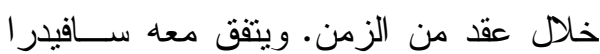

وأوبفر (Saavedra \& Opfer, 2012) في

أن سوق العمل فى القرن الحادي والعشرين

أصبح يحتاج متعلمــين يمنلكــــون مهــار ات

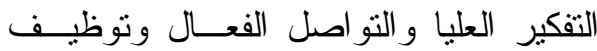

التقنيات الحديثة التى تمكنهم من إضافة قيمة

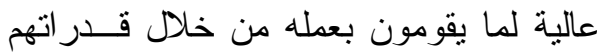

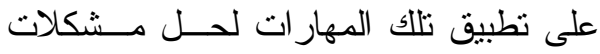

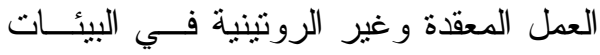

يشهد القرن الحـادي و العـشرين - ئسة

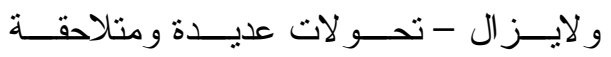

ومتز اكمة أثرت بشكل واضح على مجالات

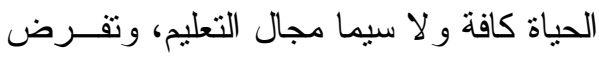

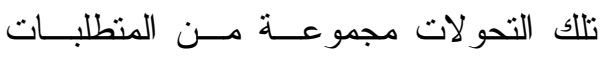

الرئيسة التي يجب على القائمين على التعليم

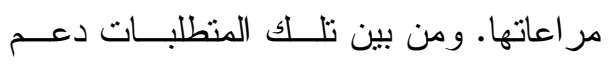

المتعلمين في المراحل التعليميـــة المختلفــــة

لمو اجهة الحياة العملية و التفاعل مع العــصر

الحالى ومعطياته المتغيرة، من حيث تسلحهم ولهي

بمهار ات القرن الو احد و العشرين. فــالتعليم

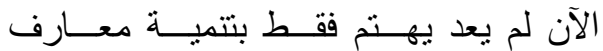

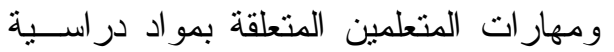

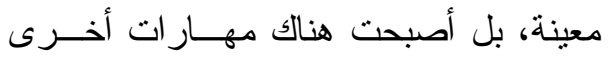

يجب تتميتها لديهم لإعدادهم إعدادا مناسـبًا

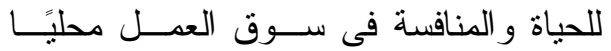

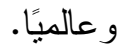


يحتاج سوق العمل الــى أفــــر اد لــديهر مهار ات غير تقليدية منل المبادأة وتحمل لمتل

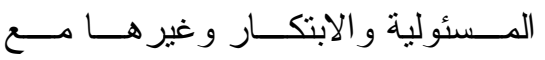
المهار ات المتتو عة.

- انخفاض القدرة التتافسية للطلاب: حيث

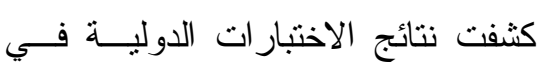

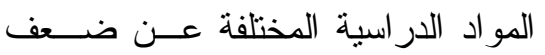

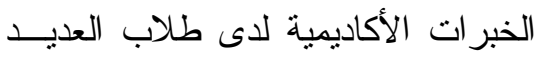
من الدول فى مراحل التعليم المختلفــة،

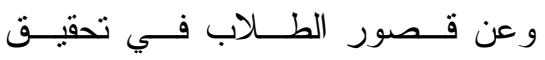
المستويات العالمية لتلاك المناهج.

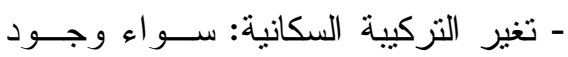
مشكلة في زيادة عدد السكان من كبــار

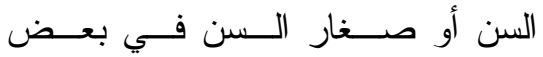

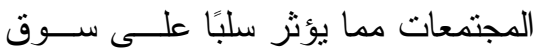
العمل؛ ومن ثم كانت هنالك حاجة ملحة إلى رفع كفاءة وقدرات الفراد العاملين، و الر اغبين في دخـــول ســـوق العــــــ

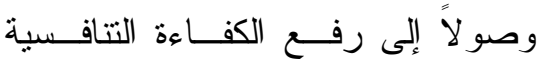

$$
\text { للمجتمع. }
$$

وتمنتل تلاك التحــديات التــى تواجـهـ

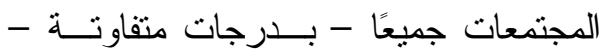
القيام بمحاو لات عديدة من المتخصصين في

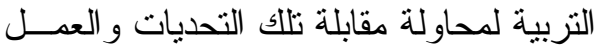
على تحديد المهارات اللازمة للطلاب خلال

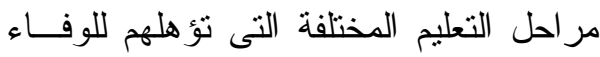

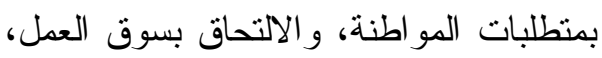

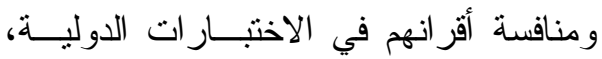

ومن ثم أصبح التحدي الرئيسي للنظخ

التعليمية كما ذكر كي وجرينهيل \&ay ) يتمثنـل فـــــ Greenhill, 2011)

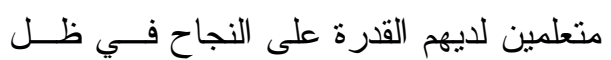

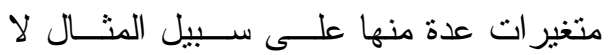

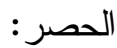
- اقتصاد يقوده المعرفة و الابتكار .

- سوق عمل يمتـــاز بالتتافـسية العاليـــة

$$
\text { و التجديد المتو اصل. }
$$

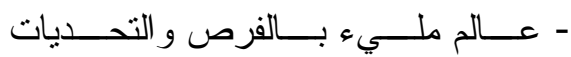

$$
\text { و المخاطر المتعددة. }
$$

- مجتمع يو اجه أعمــالا معقــدة، وغيــر

$$
\text { تقليدية ومتجددة. }
$$

ومن ضمن التحديات التــي و اجهــت

النظم التعليمية في العديد مــن دول العـالم

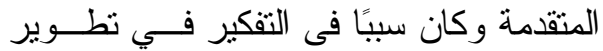

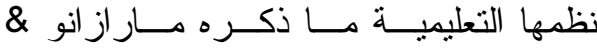
(Marazano \& Helfebower, هيلفاوير (2012، وسونو (Suto, 2013) - تغير منطلبات المواطنة: حيث يجب أن يتصف المـــواطن بــالتتور المعرفـي، و الرياضي، و التكنولوجي، و القدرة على بلى لون

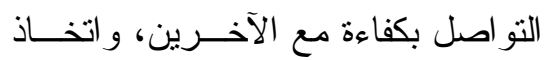
قر ار ات سليمة في مو اقف حياته. - تغير مهار ات سوق العمل: بحيث لم تعد المهار ات المطلوبة في سوق العمل نلاك المهار ات الأكاديمية التقليدية التى تقدمها النظم التعليمية الحالية للمتعلمين، ولكــن 
جوانب الحياة تستوجب من الفــرد امـتـلاكد مهار ات تمكنه من تكييفها لصالحه.

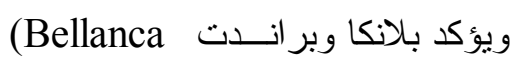

\& Brandt, 2010) القرن الحادي و العشرين في مناهج التعلــيم

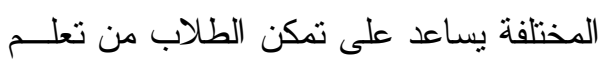

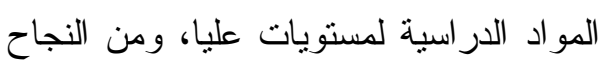

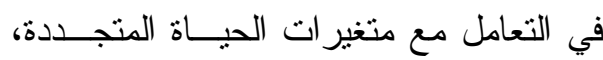
ويضيف كاى (Kay, 2010) إلى ذلـــــ أن دمج تلك المهار ات يوفر إطارًا منظمًا يضمن إنى انخر اط المتعلمين في عملية التعلم و النجـــاح في سوق العمل مستقبلا؛ وينمي لديهم الثقـــة في قدر اتهم بدرجة كبيرة.

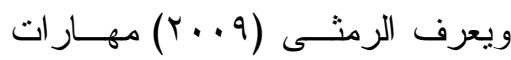

القرن الحادي و العشرين بأنها نلك المهارات التي تمكن صاحبها من التعامل و التفاعل مع بع لهاني التطور ات الحادثة من حوله، مثــل مهــارة تحمل المسئولية الفردية و الجماعية، و التكيف

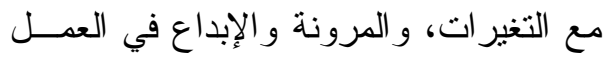
وحل المشكلات. ويعرفها ستانلي وواترمسـان ولان فئل (Stanley; Waterman; وونـــ وتتــان بأنها تللك المهــار ات Wong; Tan, 2011)

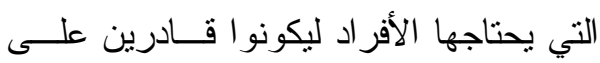
إدارة البيانات و المعلومات المتاحة و التو اصل لاصل

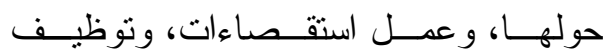

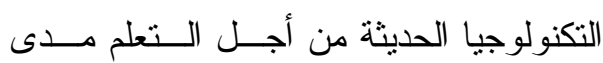
الحياة وتعميق المعرفة من أجل زيادة قــدرة

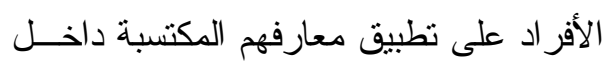

ومحاولة للاستجابة لتلك التحـديات التـي تقرض بشكل مـــا علــى الــنظم التعليميـــة ضرورة تتمية مجموعة جديدة ومتتوعة من

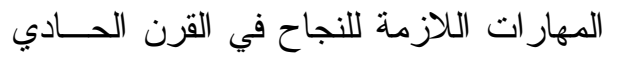

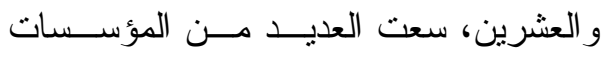
و المنظمات التعليمية إلي تحديد ثلك المهار ات

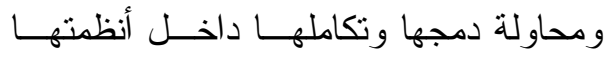

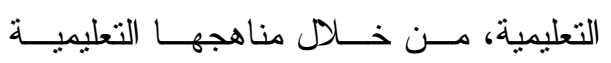

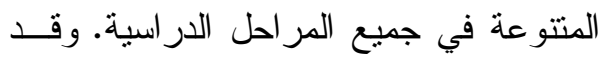

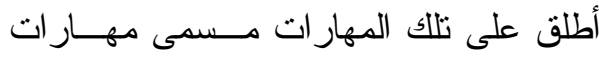
القرن الحادي و العشرين. وتــشير مهــار ات القــرن الحـــادي و العشرين إلى مجموعة واسعة من المعارف

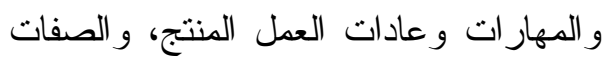

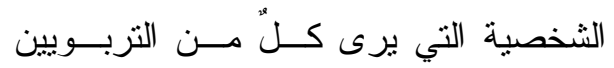

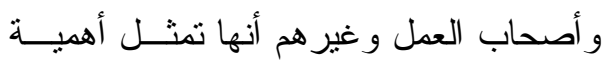
كبرى لتحقيق النجاح للفرد فى سوق العمل،

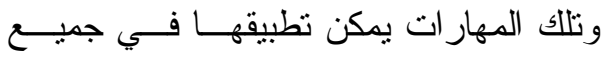
المجالات الأكاديمية و التزبوية و المهنية طو ال حبـــــاة الفـــرد. The Glossary of (The .Education Reform, 2016) وتزى رازقة المصعبي (المــصعبي،

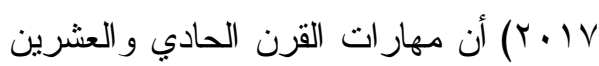
مهار ات متجددة وغير ثابتة، ومن الــصعب

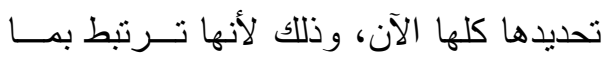

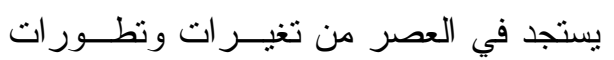

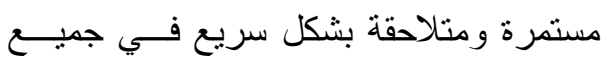


- مهار ات التفكير الإبداعي: وتعنى مهارة الاستدلال و التفكير العليا ومهارة التفكير

بالمخاطرة. وتتضمن مهار ات المرونــــة و التكيف و التوجيه الذاتي و الابتكار .

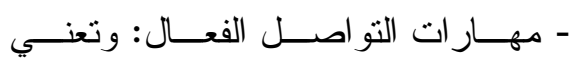
مهار ات التعبير عن نفسه بشكل خلاق،

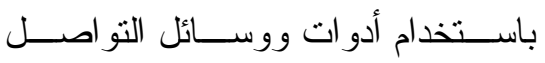

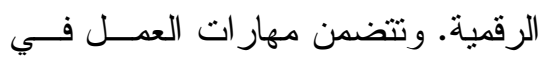

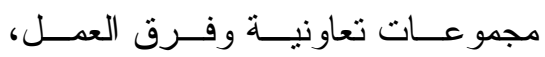

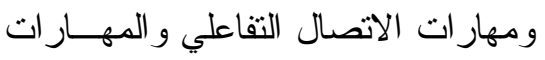
الثخصية و الاجتماعية.

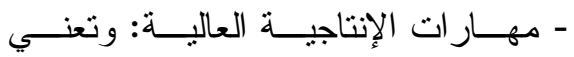

مهارات الانجاز الفعال للمهام الحياتيــة المتتوعة. وتتضمن مهارات التخطــيط و التتظيم والإدارة لإنجاز المهــام مــن خلال نوظيف فعال للأدو ات و الثقنيــات المتاحة في العالم الو اقعي.

وفى نفس الإطار قـسمت منظمــة

Organization التعاون و التتمية الاقتصادية for Economic Cooperation and (OECD, 2005) Development مهار ات القرن الحادي و العشرين إلى ثــلاث مهار ات رئيسة تمنلت فيى:

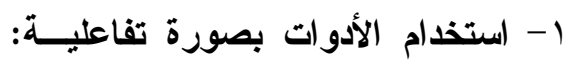
وتتضمن اســتخدام اللغـــة والرمــوز

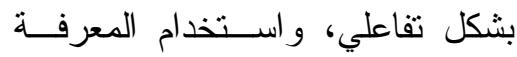

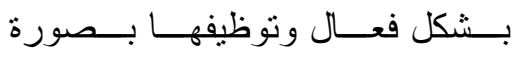

المناهج المدرسية في مواقف الحياة اليومية، ولحل المشكلات المعقدة وغير الروتينية. وقد بدأت الجهود و المحاو لات لتحديد

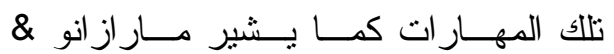
(Marazano \& Helfebower, هيلفاوير (2012 عقب تقرير وزارة العمل بالو لايات

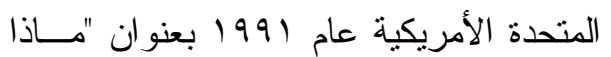

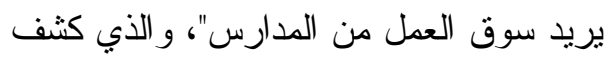

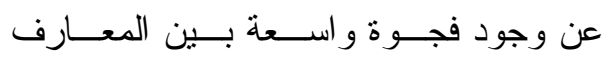
و المهارات التى تحاول المــدارس إكـــابها للمتعلمين في المر احل الدر اســـية المختلفـــة، وبين ما يحتاجه سوق العمل ومو اقف الحياة المتتو عة و المتجددة. وقد قام المختبر التعليهـي الإقليمـي

الـشمالي المركــزي North Central Regional Educational Laboratory, (2003 بتقسيم مهــارات القـرن الحــادي و العثرين إلى أربع أقسام رئيسة تمنتلت في: - مهارات التقنية الرقمية: وتعني مهـارة

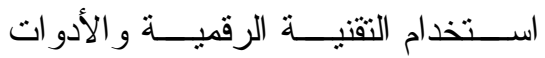
التكنولوجية، وشبكات الأنترنت للوصول

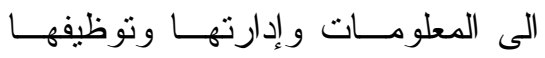

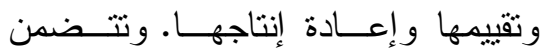

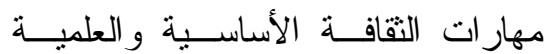

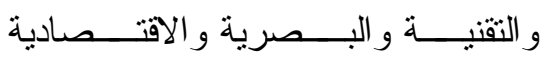

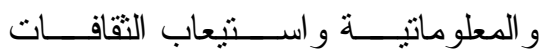

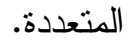


ويرى شيليفر (Schleicher, 2015)

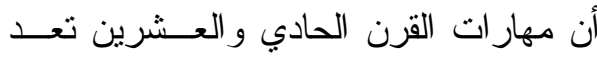

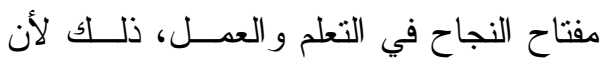

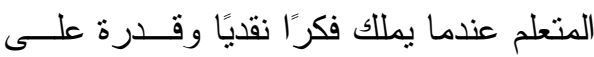
تحديد المشكلات بدقة و التعامل معها بأسلوب علمي، مما يجعله خلاقًا ومبدعًا في حل مهام العمل، وتتاح له خبر ات تعلم منتوعة وتجعله

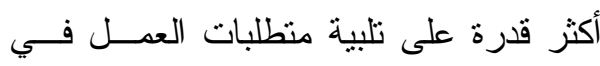

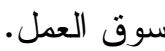
وحيث إن مرحلة التعليم الابتدائي تمنل الأساس القوي لبناء شخصية المتعلم و إعداده

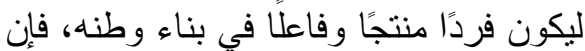
كثير ا من الدول بدأت في إجــر اء تعــديلات جذرية في كافة مناهج التعليم بصفة عامسـة، ومناهج الرياضيات بصفة خاصة في جميـع المر احل التعليمية حتى تضمن مهار ات القرن الحادي و العشرين في مناهجها، وحيــث إن كتاب الرياضيات المدرسي يمثل الــصورة التطبيقيــة المعبــرة عــن محتــوى مــــهج

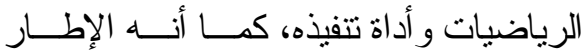
المنظم الذي يحكم ويحدد العلاقة بين كل مــن

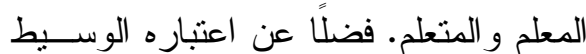
الذي يرشد المعلم إلى الطر ائق التي يـستطيع

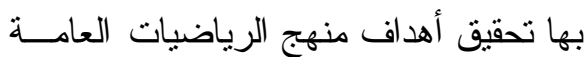
و الخاصة لذا من الضروري التحقق من مدى الهى تضمن مناهج الرياضيات لتلك المهار ات. ولكي تتمي المناهج الدراسية مهارات القرن الحادي و العشرين يجب أن تهنم بستة
صــحيحة، عــلاوة علــى اســتخدام

التكنولوجيا الرقمية بشكل تفاعلي.

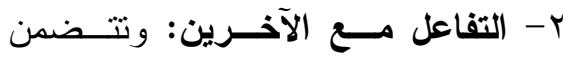

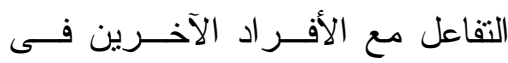
مجموعات منباينة بشكل جيد، و القدرة

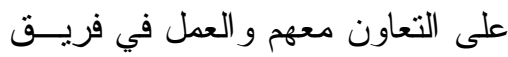

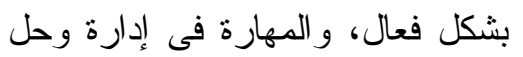

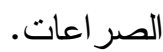

r- الاستقلالية: وتتضمن التصرف بشكل

مستقل فى المو اقف الحياتية، و المهارة فى التخطبط و التنفيذ لخطـــ حياتيـــة ومشروعات شخصية، و القدرة عـن الدفاع عــن الحقــوق و الاهتمامــات و الاحتياجات الثخصية.

ويذكر نريلنج وفاضل و (Trilling \& Fadel, 2009) و العشرين الرئيسة تتمثل في ثلاث مهــار ات

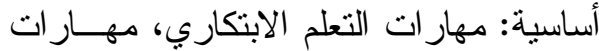

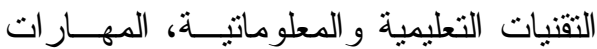
الحياتية و المهنية. بينما يحتاج الطلاب مسن

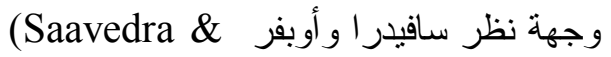
إلى سبع مهــار ات هامــة Opfer, 2012) للنجاح في القرن الحادي و العشرين تتمثل في التفكير الناقد وحل المـشكلات، المـشـاركة و التعاون و القيادة، التو اصل بفاعلية، المرونة و التكيف، الخيال وحب الاسنطلاع، المبـادأة و التوجيه الذاني، الوصول إلــى المعلومــات وتحليل البيانات. 
- موضو عات تهدف إلى تتميــة قــدرات المتعلمين على اتخاذ القرارات الــليمة في الوقت المناسب. - قيم اجتماعية، و اتجاهات، و أوجه التقدير التى يجب تتميتها لاى المتعلمين.

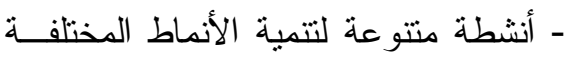
من التفكير (الناقد - الإبداعي- التأملي- التهئ التخيلي - المستقبلي - ...الخ)

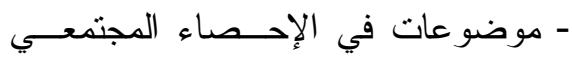

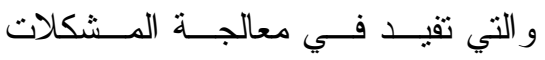

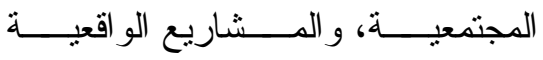
و الحياتية.

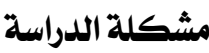
تنامى الإحساس بالمشكلة لاى الباحث مسن

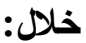

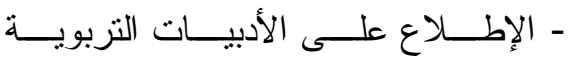
و الدراسات السابقة التى أوضحت أهمية تطوير مناهج الرياضيات فـى ضـــوء مهار ات القــرن الحــادي و العــشرين وتتميتها لدى الطــلاب كدراســـة كـي وجرينهيـل و (Kay \& Greenhill, (2011، ودر اسة رايت ولى مright) (O Lee, 2014)

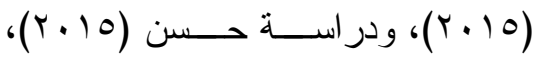
ودر اسة الخزيم و الغامدي (T ( • r). - الخبرة العملية للباحث من خلال منابعته لتدريس الرياضيات بالمرحلة الابتدائية؛

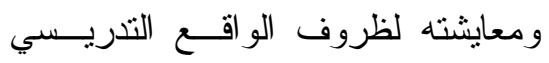

عناصر كما أوضحت منظمة الثر اكة مسن أجل مهار ات القرن الحادي و العشرين Partnership for $21^{\text {st }}$ Century Skills

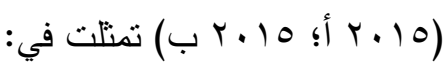

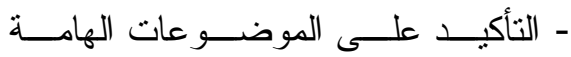

$$
\text { و الرئيسة. }
$$

- التأكيد على مهار ات التعلم المتتوعة. - استخدام أدوات القرن الحادي و العشرين لتطوير مهار ات التعلم المتتوعة. - تتم عملية التعليم و التعلم في سياق القرن

$$
\text { الحادي و العشرين }
$$

- تركز المناهج على المحتوى المناســب

$$
\text { للقرن الحادي و العشرين }
$$

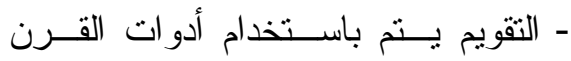

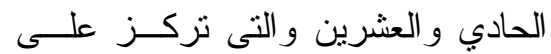

$$
\text { قياس تلك المهار ات. }
$$

و عند بناء منـــاهج الرياضــيات فـى لـى

القرن الحادى و العشرين بالمر احل الدراســـية المختلفــة يجــب مر اعــاة مجموعــة مــن الاعتبار ات الهامة حددها روفائيل ويوسـف فرك

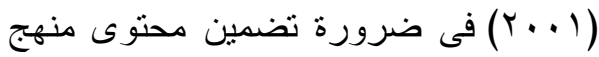

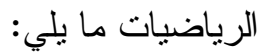
- تطبيقات رياضــية تتعلـق بمـشكلات لــات

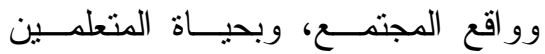

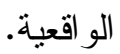
- موضوعات تهذف الى تدريب المتعلمين

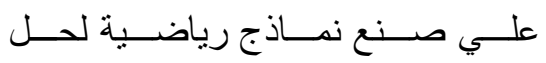
المشكلات الو اقعية و الحياتية. 


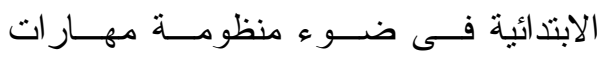

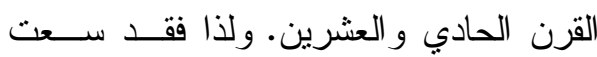

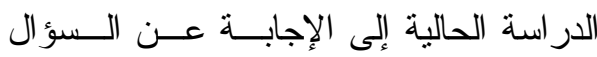

الرئيس التالي: إلى أي مدى تتوافر منظومة

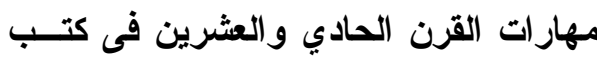
الرياضيات المطورة بالمرحلة الابتدائية فى ولى فئي

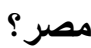

وللإجابة عن السؤال الرئيس للبحث لابد من

الإجابة عن الأسئلة التالية:

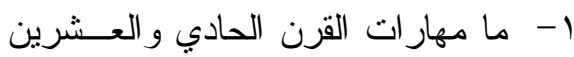

الو اجب تو افر ها فى كتب الرياضيات

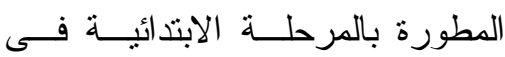

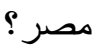

r- ما درجة نو افر مهار ات القرن الحادي

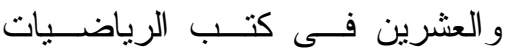

المطورة بكل صــف دراســي مـن

صفوف المرحلة الابتدائية فى مصر؟

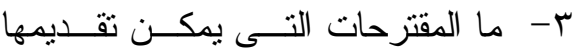

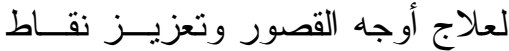

القوة فى كتب الرياضيات المطـــورة

بالمرحلة الابتدائية فـى مسصر فـى

ضوء منظومة مهار ات القرن الحادي

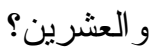

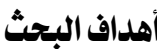

يهذف البحث الحالي إلى التعرف على:

ـ ـهارات القــرن الحــادي و العـشرين

الو اجب تو افر ها في كتــب الرياضــيات

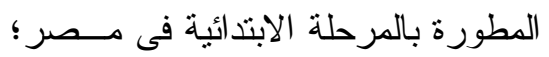

للرياضيات فقد لاحــ عــدم الاهتمــام

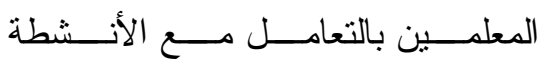

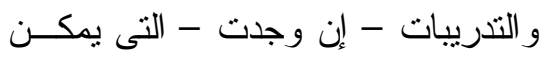

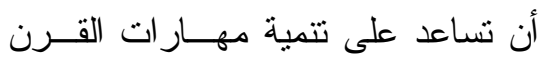
الحادي و العشرين لدى تلاميذهم.

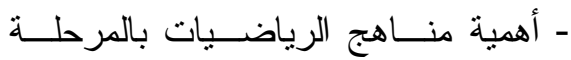

الابتدائية باعتبار ها أحد أدوات المنظومة

التعليمية التى يجب إخــضاعها للتقـــــيم

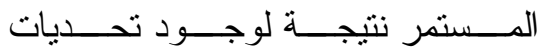

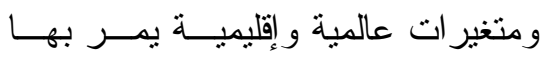

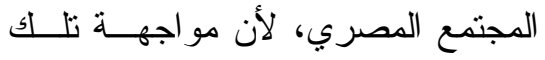

التحديات هي السبيل الوحيد للنهـوض لـوض هوض

بالمجتمع في مجالات الحياة كافة. وحتى هئى

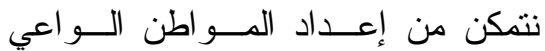

بمستجدات العصر الحالي و القادر علـى لـى المساهمة في إحداث تغييره.

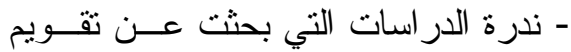

محتوى كتب الرياضــيات بجمهوريــة

مصر العربية فى ضوء مهار ات القرن

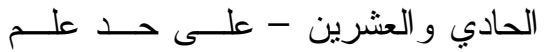

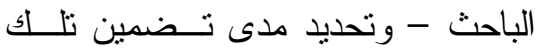

المهارات فى محتوى الكتب. وخاصـــة

كتب الرياضيات فى المرحلة الابتدائيــة

التي يجب أن نبدأ فيها بإكساب الطلاب

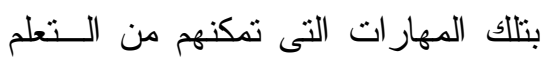

و النجاح مسنقبلا.

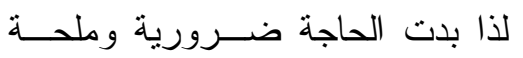

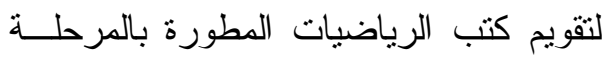


وتجنبها في مناهج المرحلـــة الإعداديـــة

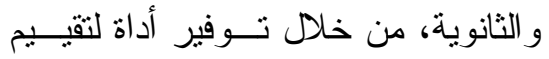

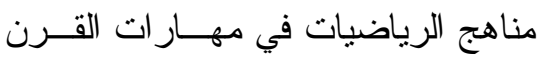

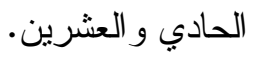

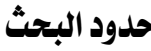

يقتصر البحث الحالي على الحدود التالية: - بعض مهارات القرن الحادي و العشرين

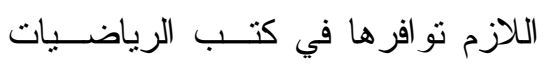

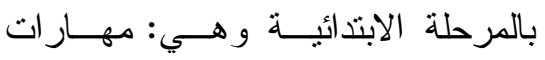

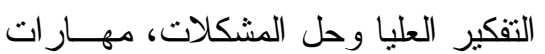

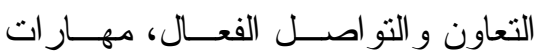
الحياة الاجتماعيـة، مهــار ات التتــور

$$
\text { المعرفي و التكنولوجي. }
$$

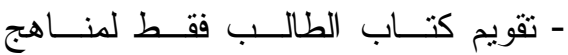

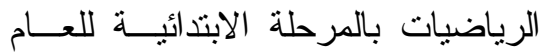

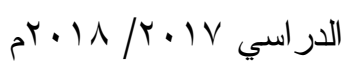

مصطلحات البحث

تقويم كتب الرياضيات المطورة:

- يقصد بتقويم كتب الرياضيات المدرسية

في البحث الحالي: بأنها عملية منهجيــة

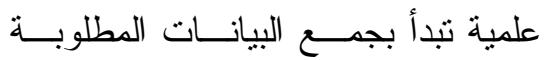
و المحدة في ضوء معايير موضوعية، لئح لتحديد مدى تـــوافر مهــار ات القــرن

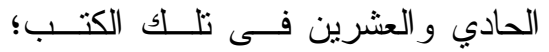
وتتتهي باتخاذ القرار ات المناســبة فــي ضوء تفسير تلــك البيانـات؛ و إعــداد مقترحات لعلاج أوجه القصور وتعزيز نقاط القوة.
وذلك من خلال إعداد قائمة خاصة بتلك المهار ات. - مدى تو افر مهـــار ات القــرن الحـــادي و العشرين فى كتب الرياضيات المطورة بكل صف در اسي من صفوف المرحلة

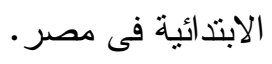
- تحديد جو انب القوة و الضعف في كت بـب الرياضيات المطورة بالمرحلة الابندائية بمصر فى ضوء منظومة مهار ات القرن

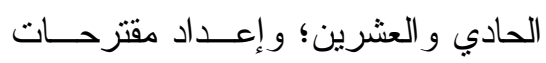

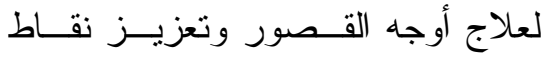
القوة.

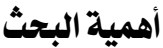

\section{يفيل البحث الحالي فيما يلي:}

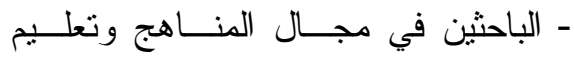

الرياضيات لإجر اء بحوث أخرى تنتاول

تحليـلـل كتــب الرياضــيات المطـــورة

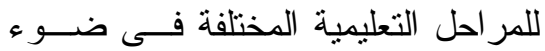
مهار ات القرن الحادى و العشرين بالدول العربية باستخدام أداة التحليل المعدة في

$$
\text { البحث الحالي. }
$$

- مخططي مناهج الرياضيات ومطوريهــا

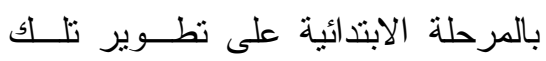

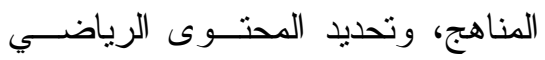
المناسب في ضـــوء مهـــار ات القــرن الحادي و العشرين. - مخططي مناهج الرياضيات ومطوريهــا فى الكثف عن جوانب القصور الحالية 


\section{أدبيات البحث}

المحور الأول: تقـــويم الكتـــاب المدرســــي للرياضيات:

المر اد بالكتاب المدرسي تلك الكتهب باتب

المتداولة في المؤسسات و المدارس التربوية

بمختلف مستوىاتها؛ ويمنل الكتاب المدرسي

المنهل أو المعين الذي يستمد منـــه المــتعلم معلوماته فهو يمثل خبرة الأجيال وتر اكماتها، فالكتاب المدرسي هو الأداة الأولى التي تعبر

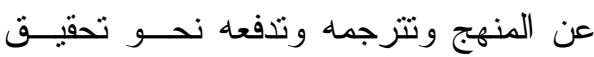

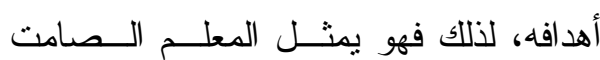

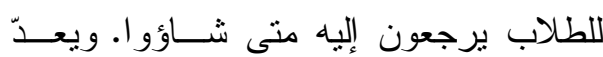

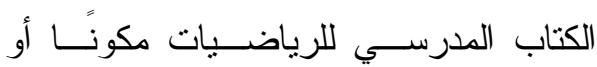

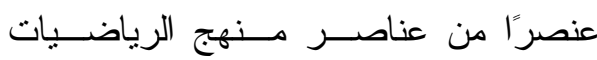
بمفهومه النظامي الحديث؛ ومن خصائُ مصه أنه كتاب تعليمي مخطط و هــادف ومحســده،

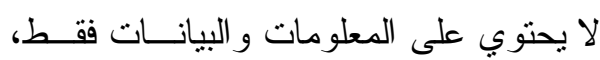

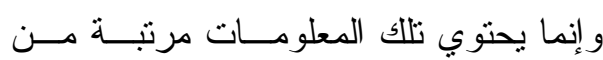
السهل إلى الصعب ومن البسيط إلى المركب

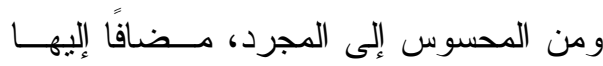

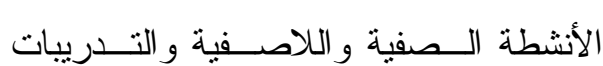

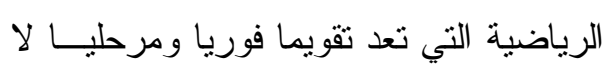
بد منه في عملية تعليم الرياضيات وتعلمها.

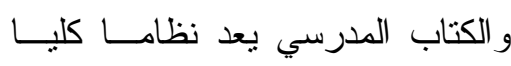
يتتاول عنصر المحتوى في المنهج، ويشتمل

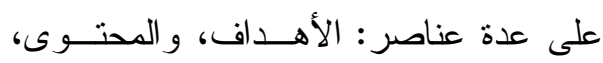
و الأنشطة و التقويم، ويهدف إلـى مـسـاعدة
منظومة مهارات القرن الحادى و العشرين - يقصد بمنظومة مهار ات القرن الحــادي

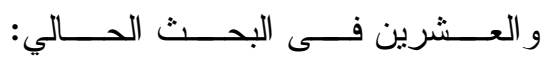
بأنها مجمو عة مهار ات شاملة ومنظمـــة بشكل متكامل تمثــل مهـــار ات الــتعلم الحياتية و الأكاديمية الكافية و الضرورية

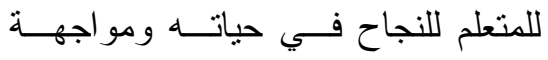

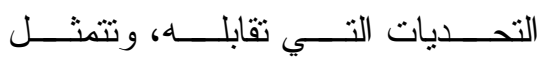
تللك المهـار ات فـي أربــع مهــار ات

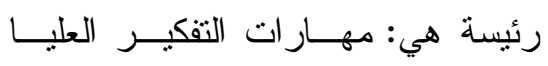
وحل المشكلات، ومهــار ات التعـاون و التو اصل الفعــال، ومهــــار ات الحيــــاة الاجتماعية، ومهار ات التتور المعرفــي وني

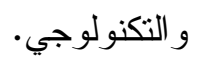

\section{منهج البحث: - م}

يعتمد البحث الحــالي علــى المــنهج

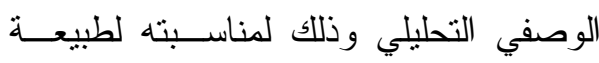

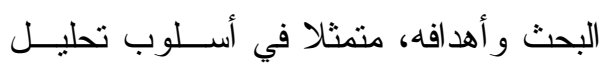

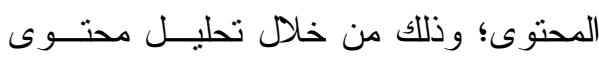
كتب الرياضيات بالصفوف من الأول حتـى ونى نونى السادس الابتدائي في الفـــلين الدراسـيبين

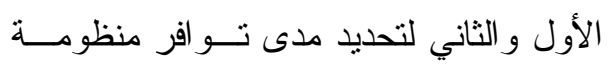

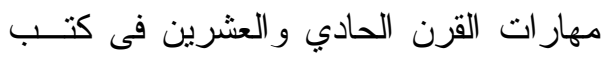
الرياضيات المطورة بالمرحلة الابتدائية فـى ونى مصر 
وما يزال الكتاب المدرسي إلى اليــوم

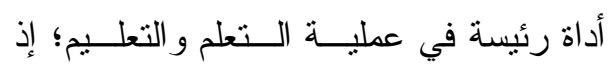

يستخدمه المعلم في تخطيط عمله التدريسسي ويسي

قبل الشروع بتنفيذه، وفي أثناء عملية التعليم،

ليثير انتباه تلاميذه ويمكنهم من الفهم. وييقى وفئي

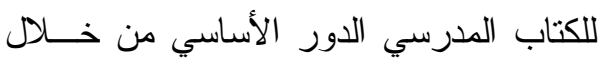

كونه الأداة المهمة في تتفيذ المنهج الدراسي للدي لاسي

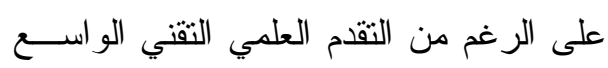

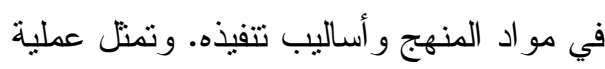

تقويم كتاب الرياضــيات المدرســي عمليـــة

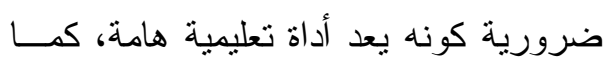

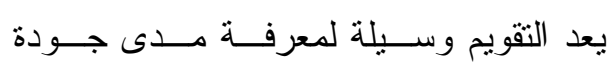

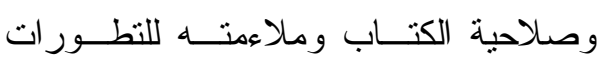

العلمية المتسار عة؛ و التىى تتطلب إعادة النظر

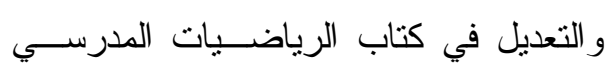

بصورة مستمرة.

وتتركز أهية الكتاب المدرسي كمـــا

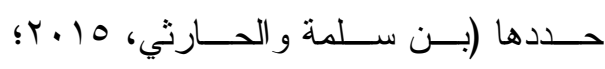

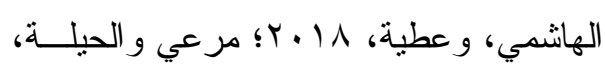

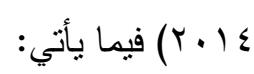

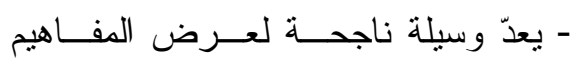

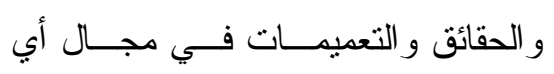

موضوع من الموضو عات الدر اسية.

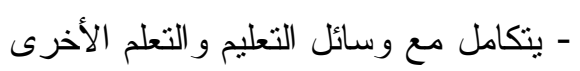

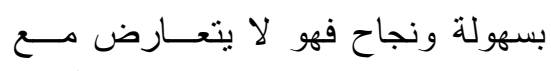

الأساليب الأخرى، بل قد يكون مكميًا لها

ومنكاملًا معها.
المعلم للمتعلمين فى صف ما، وفـى مــادة

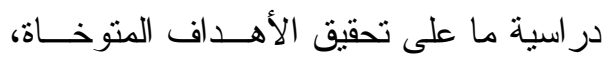

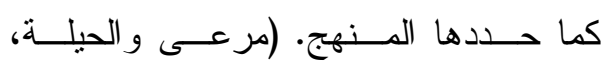

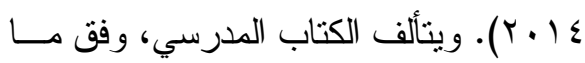

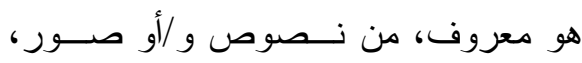

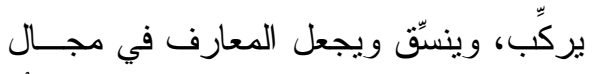

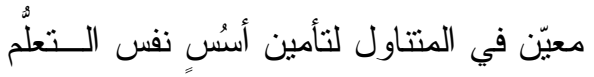

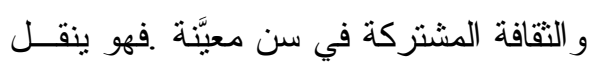

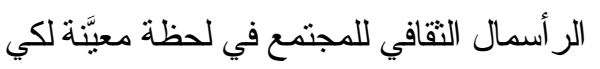
يستقيد منه الأصغر سنا من أبناء وبنات هذا

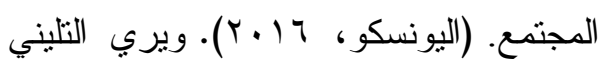

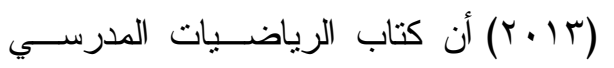
يمنل وثثقة رسمية مكتوبة ومنظمــة بـشكل

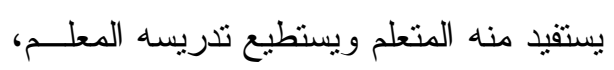

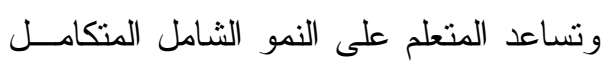

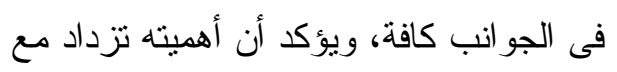
ازدياد النطور ات التكنولوجية.

ويستمد الكتاب المدرسي قيمته فـي

المقام الأول كما برى بن ســلمة و الحـــارثي فئهي

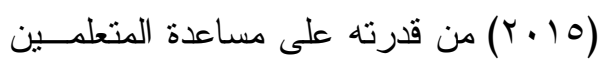

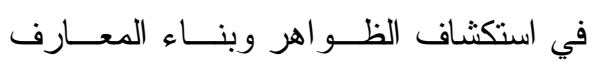

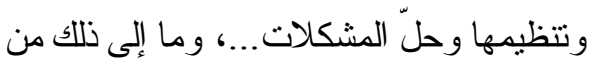

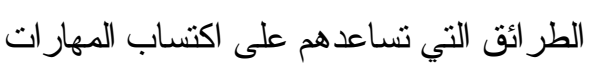

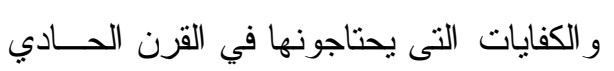

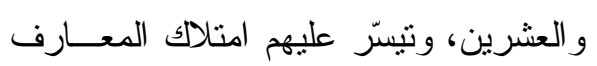

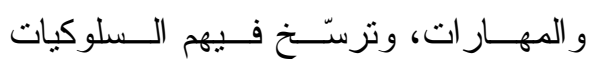
المستهدفة. 
التزبوية وطر ائق التشريس. فلم يعد المعلـــم

يعتبر الكتاب المدرسي المرجع الوحيد للعملية

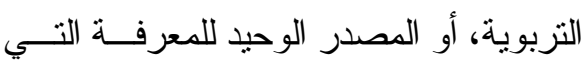

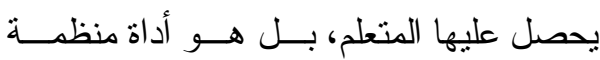

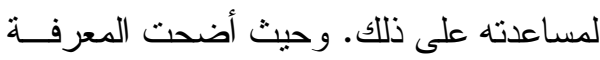

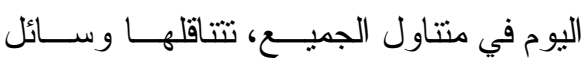
مختلفة وتزخر بها مصادر متعدّدة.

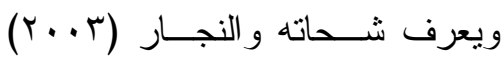

تقويم المنهج بأنه "تقـــويم ذو بعــدين: الأول ولثر محدود، وهو إصدار الحكم علي بنية المنهج

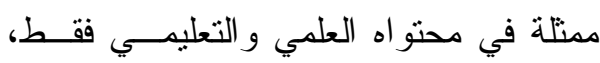
وتحديد مدى جودة المحتوى و اتساقه وقدرته على تحقيق أهداف المنهج، ومن ثم تعـديل جو انب القصور و الضعف فيه. و الثاني أكثر شمو لا، حيث يشخص ويعالج جميع جو انــب عناصر المنهج، سو عا المعلم، و الهيئة الفنيـــة والادارية المعاونة له، أو المتعلم، أو البيئــة

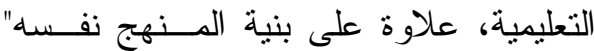

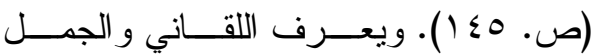

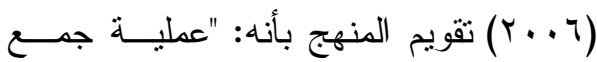

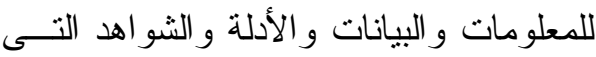
تثير بعد حصرها وتحليلها وتقسيرها إلـى

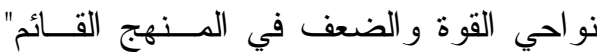
(ص) ن. ن (^)

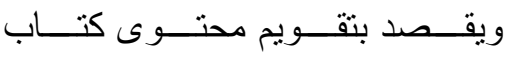

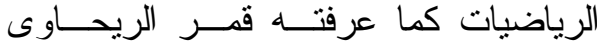

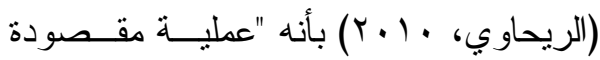

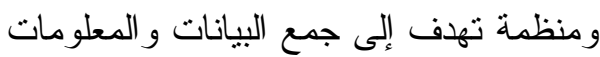

- يعدّ أداة مرنة يمكن اســـخدامها داخــل الــصف الدر اســـي وخارجــه، كـــللك في التعلم الفردي، و التعلم الجمعي، كما ودان يمكن استخدامه في أي وقت مسن دون

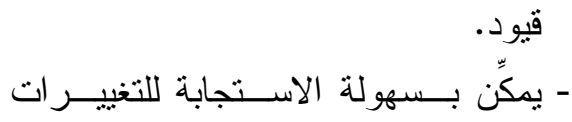

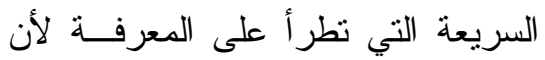

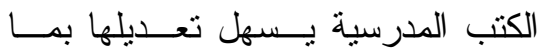
يتمشى مع هذه التغيير ات. - يضمن توحيد جو انب المحتوى الرياضي لدهي لطلاب الصفوف الدراسية المختلفة. - يمكّن الكتاب المدرسـي مــن التقــــيم السريع لمدى التقدم الذي أحرزه الطلاب

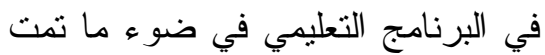
در استه من هذا الكتاب.

وعموماً يمكنا القــول: إن للكتــاب

المدرسي للرياضيات مكانسـة أساســية فــي لي

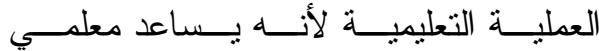
الرياضيات على مهمــاتهم، فهــو الوعـــاء الحامل للمادة العلمية، و هو الر ابط الأساسـيـي لرئي بين و اضعي المنهج و المتعلمين في قاعـات الصفوف الدر اسية. وقد تغيرّت النظرة إلـى

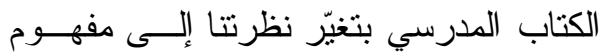

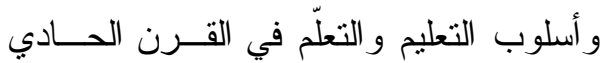

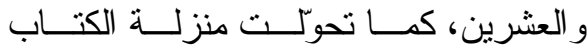
المدرسي و واستخدامه مــن قبــلـ المعلمــين و المتعلمين في حصّة الدرس مع التحــــلات

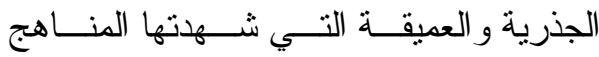


الابتدائية قد بلغ ( (ـ٪\%)؛ در اســة الغامــدي

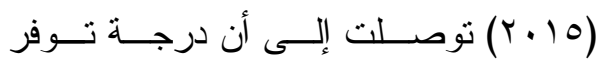

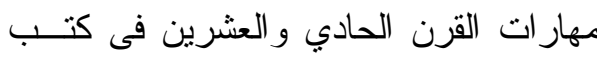

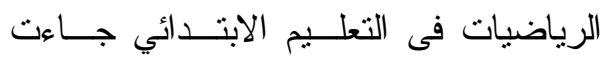

منوسطة.

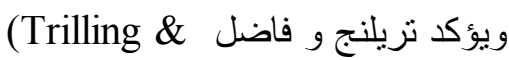

Fadel, 2009)

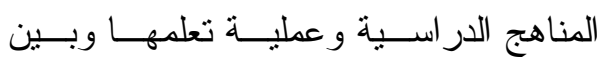

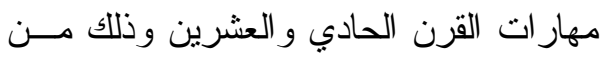

خلال إثر الك المتعلمين بعمق في نـشناطات

التعلم، بغرض أن يكونو ا متعلمين وعـاملين

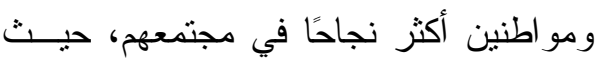

يجب علي المعلم و المتعلم النتسيق فيما بينهم

في إدارة عملية التعليم و الــتعلم، و الاعتمـــاد

بشكل رئيس على طريقة المناقثة و الأســـئلة

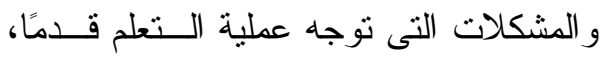
وبذللك يتحقق هدف تتمية مهار ات الابنكــار و الإبداع لاى المتعلم من خلد المنافسة فــي لهي التفكير وممارسة أنماط متتوعة من التفكيـر

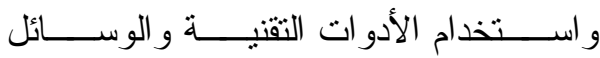

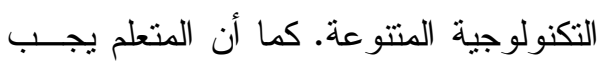
أن يقدم كل جديد فيما يقوم بإنجازه من مهام سواء كانت فردية أو جماعية من خلال فرق

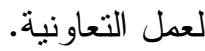

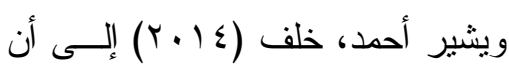

عملية البحث في جودة الكتــب الدراســية،

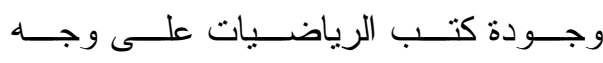

الخصوص لجميع المر احل الدراسـية مــن
عن محتوى كتاب الرياضيات لإصدار حكـــ

على مدى تحقيق المحتوى للأهداف العامـــة

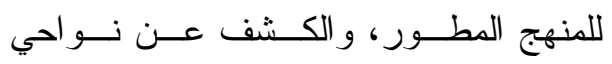

القصور فيه، وتقديم مقترحات لعلاج أوجــهـ

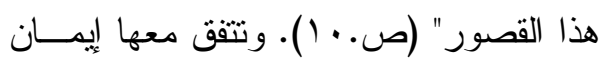

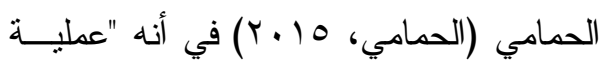

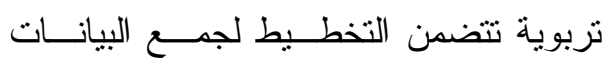

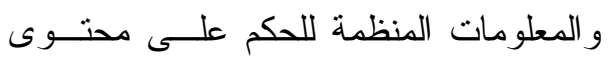

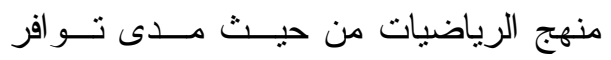
المعايير فى كتب الرياضيات بهدف التعرف إلى نقاط القوة و الضعف باســـتخدام تحليـلـل المحتوى، بقصد تطوير المحتوى وتحسينه" $(\vee \cdot v)$

تأسيسًا على ما سبق يمكن التوصـلـل

إلى أن تقويم كتب الرياضـــات المدرســية

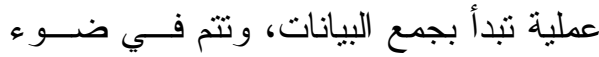
معايير موضوعية، وتتتهي باتخاذ القــر ارات

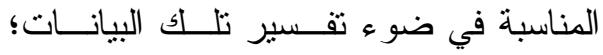
وتثتوقف صحة نلأك القرار ات على مدى دقـــة القياس، ومدى صدق وثثات أدو اته. وتتثير العديد من الدراسات التى قامت

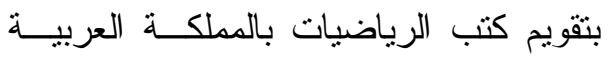

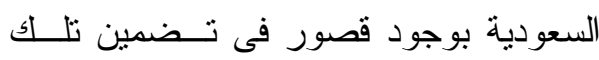
الكتب لمهار ات القرن الحادي و العشرين منها على سبيل المثال دراسة الخزيم و الغامــدي

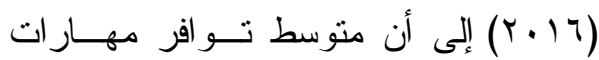

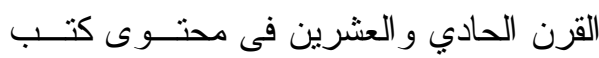

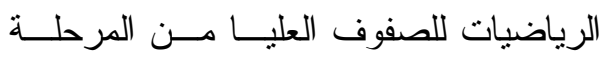


و التحديد لها باختلاف نظرة القائمين لمهار ات سوق العمل فى المجتمعات المختلفة.

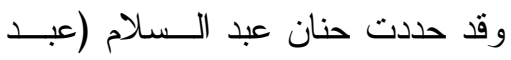

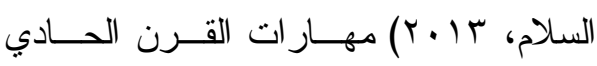

و العشرين بأنها منظومة المهار ات النى تمكن

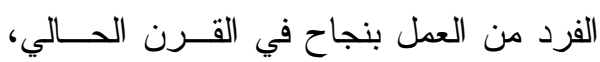

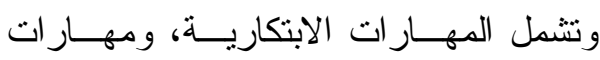

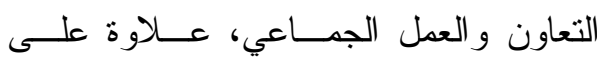

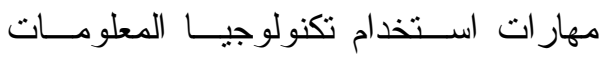

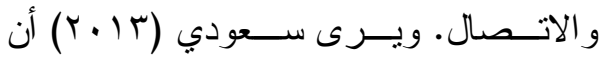

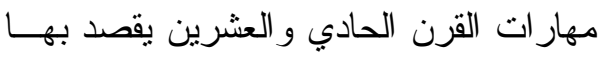

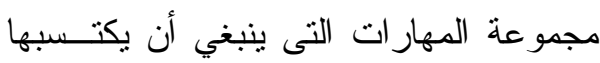

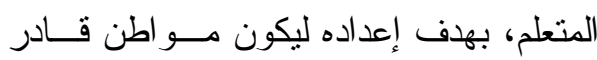

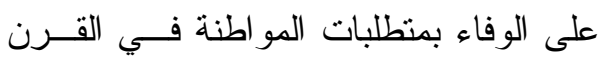

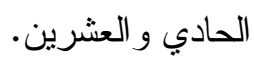

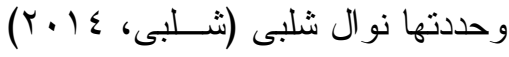
بأنها مجموعة المهار ات الضرورية لــضمان استعداد المتعمين للتعلم و الابتكــار و الحيــاة

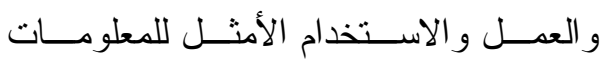
و الوسائط و التكنولوجيا في القــرن الحــادي و العشرين. ويعرف أبو حسن؛ علام؛ حسال

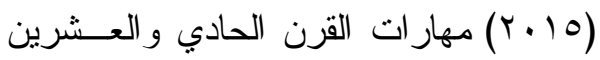
بأنها مجموعة المهار ات الأساسية النى ينبخي

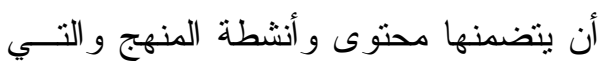

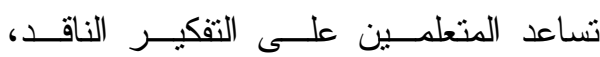
و المسئولية الاجتماعية، وتحديد المـشكلات

وصياغتها وحلها.
الموضوعات المهمة التى شاعت ولا زالـــت

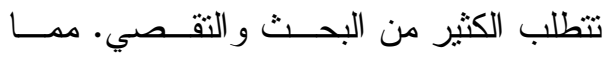
يتطلب من الباحثين و التزبــوبين و المهتمـين بتعليم الرياضيات وتعلمها إلى مر اجعة دائمة

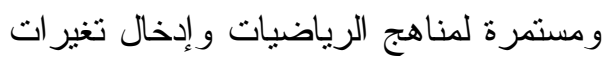

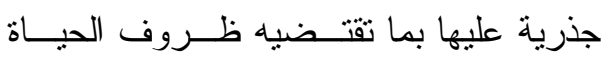
الحالية و المستقبلية. مما يعد سبيًا أخر ا للقيام

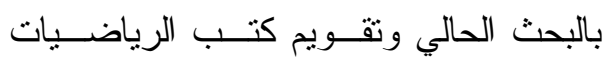

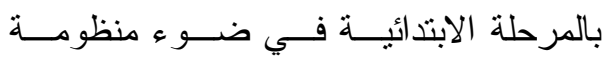
مهار ات القرن الحادي و العشرين.

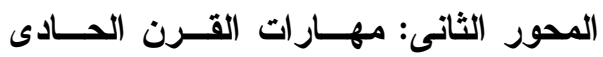
و العشرين يشير مكتب العمل الــدولى (r. Tr) فى توصياته إلى ضرورة وجود نظام تعليمي

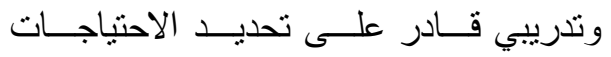

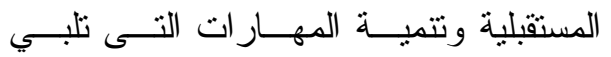
الاحتياجات لاى الطلاب، فتكسبهم مهـار ات التعلم مدى الحياة وتطبيق وسائل التكنولوجيا للوصول إلى جوانب المعرفة المختلفة، وأكد المؤتمر على أهمية إجراء الدراسات لتحديد سمات سوق العمل و المهن المستقلية وربطها بالنظام التعليمي.

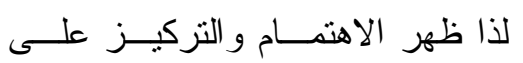
مجمو عة من المهار ات تسمى بمهار ات القرن

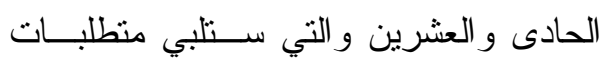
سوق العمل في كل مجتمع من خلال تضمين تللك المهارات فى المناهج الدراسية المختلفة،

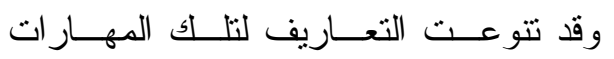


الرقمية، ومهار ات العمل و الإنتاج. بينما يرى

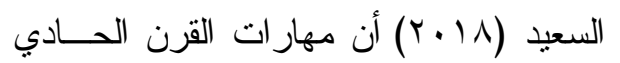

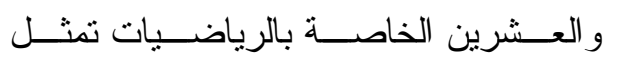
مهار ات التعلم الحياتية و الأكاديميــة الكافيـــة

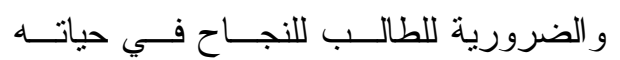

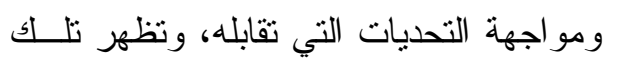
المهار ات من خلال قدرته على توجيه ذاتــهـ

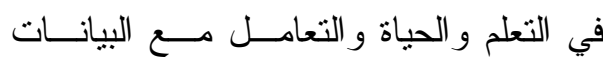
و المعلومات و المعارف المتعلقة بالرياضيات و التعاون و التو اصل مـــع الآخــرين بنجــــاح

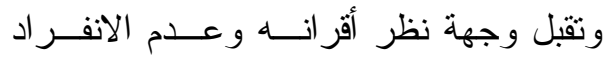

$$
\text { بر أيه. }
$$

وحدد بينكلي، ارستاد، هيرمنا، ريزن،

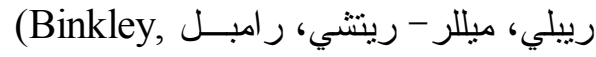

Erstad, Hermna, Raizen, Ripley, Miller-Ricci, Rumble, 2012) مهار ات رئيسة يجب الاهتمام بتتميتها مسن خلال مختلف المناهج التعليمية فــى القــرن

$$
\text { الحادي و العثرين كما يلي: }
$$

- طرائق التفكير: وتثمل المهارة في حل المشكلات، و إتخاذ القرار ات، و التفكيــر الناقد و الإبداعي، ومهار ات التفكير مـــا ولئس

$$
\text { ور اء المعرفي. }
$$

- طرائق العقل: ونتشل الطرق المتتوعة

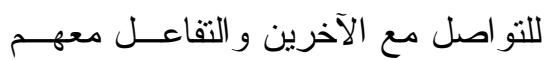

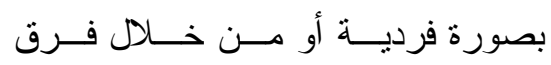

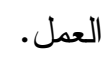

ويوضح شو اهين (10 • ب) ضــرورة

امتلاكك المتعلمين مجمو عة من مهار ات القرن

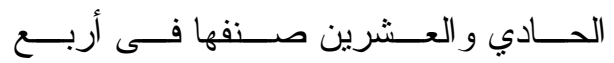
مجمو عات من المهار ات تتمنل في:

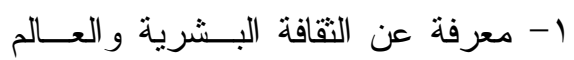

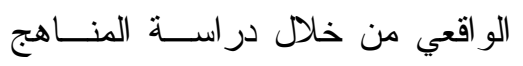
الرئيسة كالعلوم و الرياضيات و العلوم الاجتماعية و التاريخ و اللغات و الفنون.

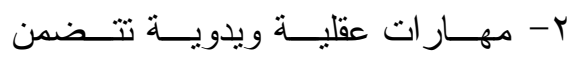

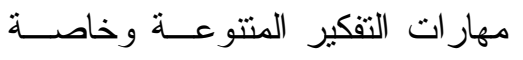
الناقد و الابتكاري، ومهار ات التو اصل وهل

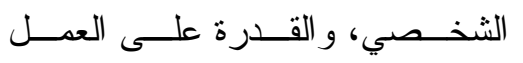
بصورة مستقلة وفي فرق العمل.

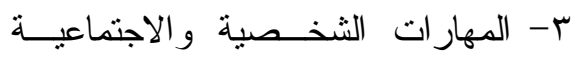
وتتضمن مهار ات وأسس التعلم مدى ولاجنماعه

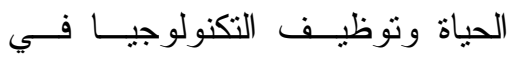

$$
\text { التو اصل و الحصول على المعرفة. }
$$

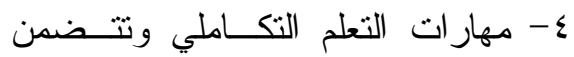
مهارات الإنجاز و التعلم عبر المــواد

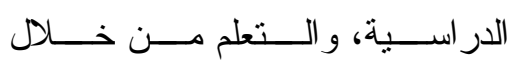
الموضو عات متعددة التخصصات.

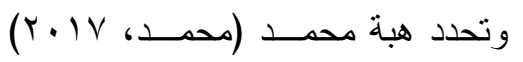
مهار ات القرن الحادي و العـشرين المتعلقـــة

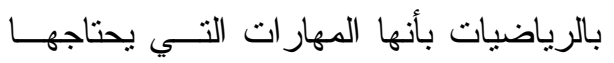

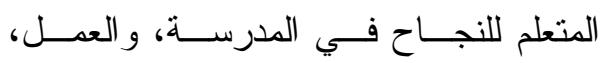
و المجتمع. وتتضمن مجموعة من المهارات

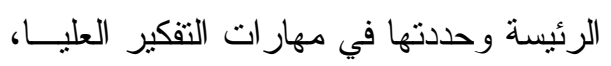

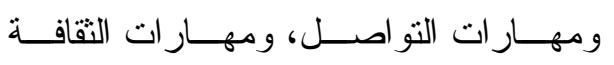


و الذي يمثل خارطـــة طريــق للمؤسـسـات

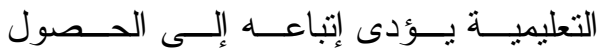

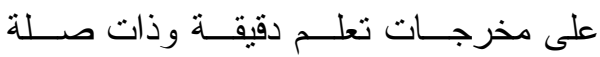
بالو اقع الحالي المتغير و المليء بالتحــديات. وتمنلت ثلاك المخرجات في إحسدى عـشرة

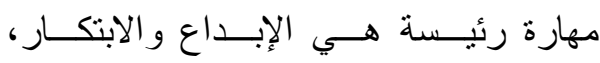

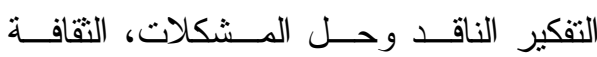

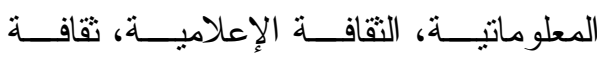

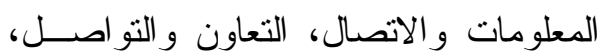

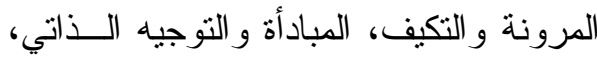
القيادة و المـسؤولية، الإنتاجيــة، اســتيعاب لاتثافات المتعددة.

وتتشير العديد من الأدبيات التزبويـــة إلى الاعتبار ات الواجب نو افرها فى المناهج

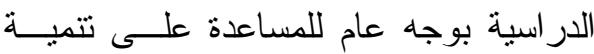

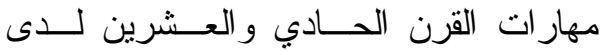

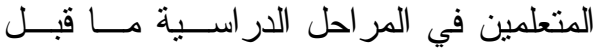
الجامعية منها على ســبيل المثنـال: النــاجم

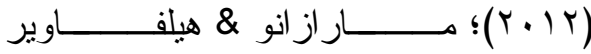
؛(Marazano \& Helfebower, 2012)

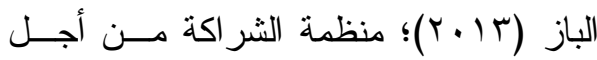
The مهار ات القرن الحسـادي و العـشرين Partnership for $21^{\text {st }}$ Century Skills

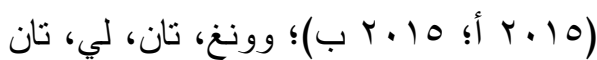
(Wong, Tan, Lee, Tan, 2017) - إنثر الك المعلمين في عملية بناء وتطوير

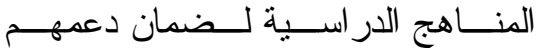

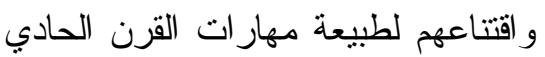

- أدوات العمل: وتتشمل توظيــف الأدوات

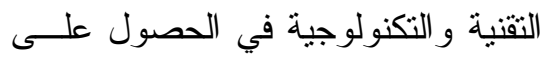
المعرفة وتحليلها و إعادة إنتاجها.

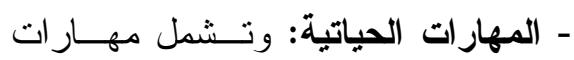

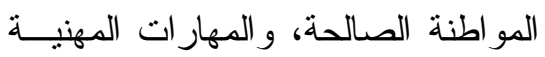

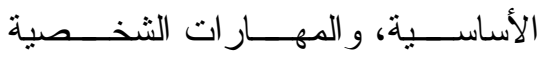
و الاجتماعية و الثقافية.

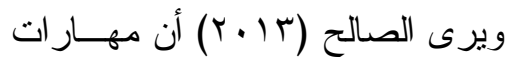
القرن الحادي والعشرين في مجال المنــاهج التعليمية تمتل عمليات التفكير التي يستخدمها

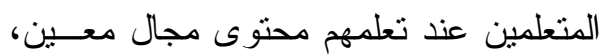
وفى العمل مع الآخرين لزيــادة اســتيعابهر

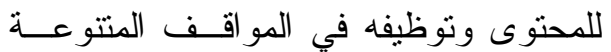

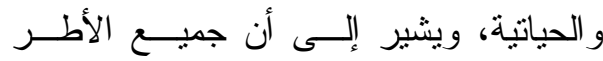

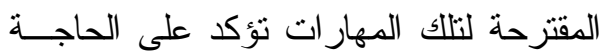
إلى دمجها في محتــوى المـــواد المختلفـــة،

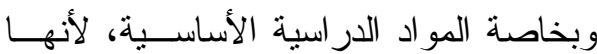
توفر للمتعلمين قدرة كبيـرة علــى الــتعلم بفاعلية، وتكوين بنــى مفاهيميــة لتخــزين و استرجاع المعلومات واســتخدامها بــشكل مستمر ، بطر ائق جديدة وغير تقليدية.

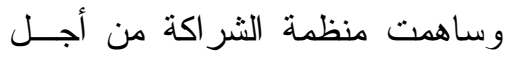
The مهار ات القرن الحسادي و العــشرين Partnership for $21^{\text {st }}$ Century Skills

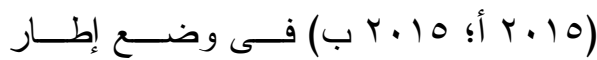
مفاهيمي لمهار ات القرن الحادي و العـشرين تساعد المتعلم للنجاح كمو اطن فاعل ومــؤثز فى مجتمعه من خلال تحديدها إطار للــتعلم؛ 


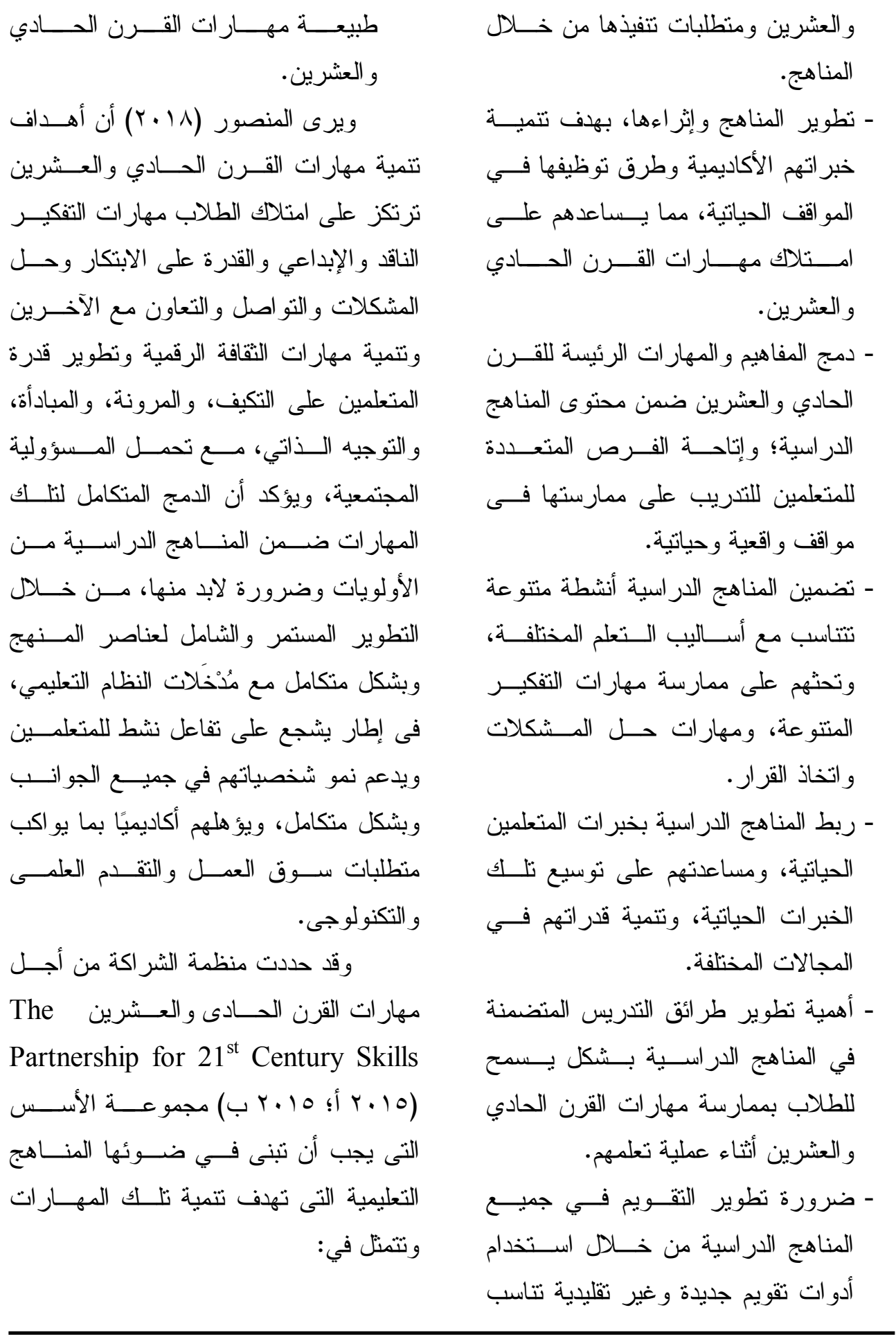


تأسيسًا على ما سبق يمكن استتناج

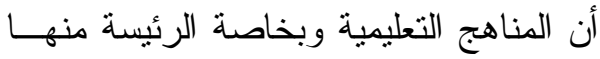

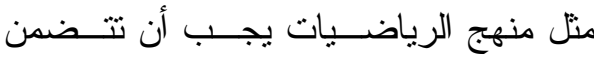

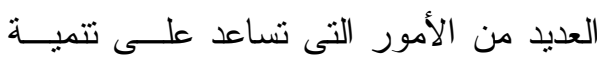

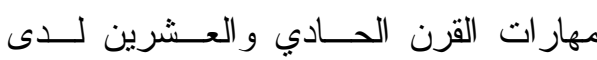
المتعلمين منها:

- ربط جو انب المعرفة الرياضية بتطبيقات من العالم الواقعي، وذللك مــن خـــلال المشكلات الحياتية.

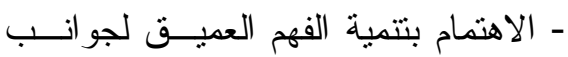

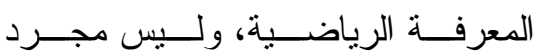

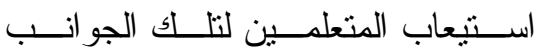
فقط. - التأكيد على ضرورة توظيف المتعلىــين

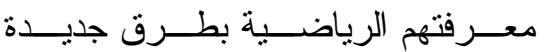
ومبتكرة، وذللك من خلال المـشروعات

$$
\text { المنتو عة. - مهن }
$$

- تضمين نــدريبات و أنسشطة رياضــية تتطلب مــن المتعلمــين التفكيـر فيمـــا يقومون به مــن إجــر اءات رياضـــية، وتقـــديم مبـــرر ات منطقيـــة تعكــس استر اتيجيات التفكير التي نم توظيفها في

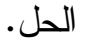
- توظيف استخدام المتعلمين للتكنولوجيــا بدرجة عالية سواء في وصولهم للمعرفة

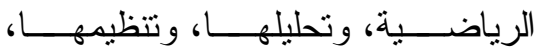

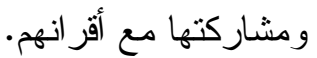

- دمج المهارات في سياق المواد الدر اسية

الرئيسة، وموضو عاتها و الموضــوعات

الفرعية وجميـع الأنـشطة التعليميــة وفئة المرتبطة بها.

- توفير الفرص المتعددة للمتعلمين لتطبيق تلك المهار ات عبر مجالات المحتوى.

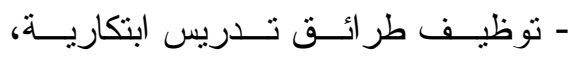

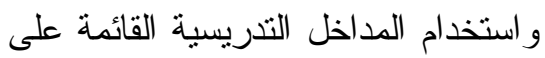
حل المـشكلات و المـشروعات، مـــع الاعتماد على تكامل تلك الطر ائق مــع التكنولوجيا التعليمية.

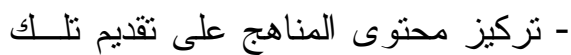
المهار ات و الخبرات المتعلقة بتوظيفهـــا

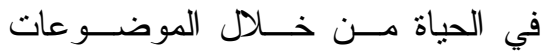
الاجتماعية التى يعيشها الطــلاب فــي حياتهم اليومية. - الاهتمام ببناء فهم مشترك وروابط عبر المو اد الدر اسية الرئيسة، و المو اد البينية، و الموضوعات متعددة التخصصات من خلال تلك المهار ات.

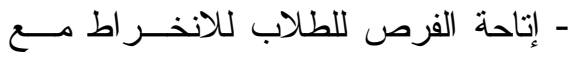
بيانات العالم الحقيقي و الخبرات الحياتية، من خلال التعامل مع المشكلات الحياتية

$$
\text { و الو اقعية. }
$$

- توفير خبرات تعليمية حقيقة وعملية من

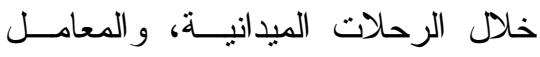
المختلفة؛ و المشاركة مع الآخرين فــي ولي تبادل الخبرات الحياتية. 


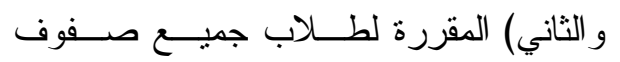

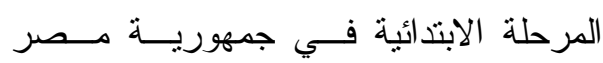

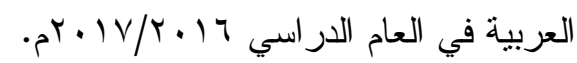
وقد شملت عينة البحث كامل مجتمــع

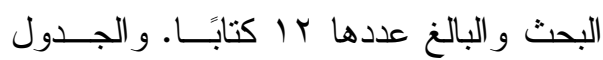

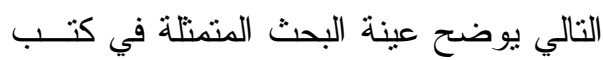
الفصلين الأول و الثاني من كتب الرياضــــات لــات بالمرحلة الابتدائية، و عدد وحداتها.
- توفير فرص تعليمية منتوعة للمتعلمــين

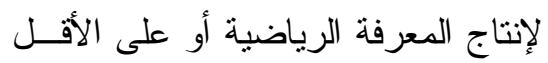
إعادة اكتثافها، وليس فقط استهلاكها. - توفير الفرص المتتوعة للمتعلمين لنشر ولئ

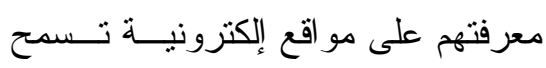

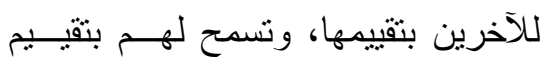
مساهمات أقر انهم.

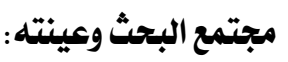
تكوّن مجتمع البحث الحالي من جميع

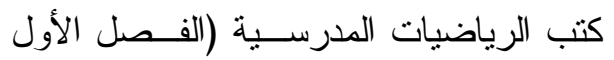

جدول (1): توزيع الوحدات وصفحات كتب الرياضيات بالمرحلة الابتدائية فى الفصلين الأول

\begin{tabular}{|c|c|c|c|c|c|c|c|c|c|c|c|c|}
\hline \multirow{3}{*}{ مجموع } & \multirow{3}{*}{ |لصفحوع } & \multirow{3}{*}{ |لدرد } & \multirow{3}{*}{ |لوحدوع } & \multicolumn{4}{|c|}{ الفصل الدراسي الثاني } & \multicolumn{4}{|c|}{ الفصل الدراسي الأول } & \multirow{3}{*}{ الابتدائية } \\
\hline & & & & عدد & عدد & عدد & عدد & عدد & عدد | & عدد & عدد & \\
\hline & & & & (الفقر ات & الصفحات & الاروس & الوحدات & الفقر ات & الصفحات & الدروس & الوحدات & \\
\hline$\varepsilon \wedge 1$ & rr. & זr & $\wedge$ & זדי & irq & 17 & $\varepsilon$ & $r 19$ & 1.1 & 17 & $\varepsilon$ & الأول \\
\hline$\leq 79$ & rOA & rq & 9 & $r \leqslant 1$ & IrV & 17 & 0 & rrA & $|r|$ & r & $\varepsilon$ & الثاني \\
\hline $0 \leq 7$ & אדי & r & 9 & אדי & rro & 11 & 。 & rیr & Irv & $1 \varepsilon$ & $\varepsilon$ & الثالث \\
\hline$T \leqslant \Lambda$ & ro. & rA & $\wedge$ & 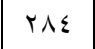 & 149 & $1 \varepsilon$ & $\varepsilon$ & ז & $|r|$ & $1 \varepsilon$ & $\varepsilon$ & الر ابع \\
\hline דצי & rV. & $\leq 7$ & 9 & ra7 & IrV & $r$. & 0 & $r \varepsilon$. & $1 \leqslant r$ & TY & $\varepsilon$ & الخامس \\
\hline TN & rVA & rv & $\wedge$ & $r \leq q$ & IrV & 17 & $\varepsilon$ & צr & $1 \leqslant 1$ & rI & $\varepsilon$ & السادس \\
\hline r & $10 \leqslant 1$ & $r \cdot \varepsilon$ & 01 & 1790 & $\vee \wedge \varepsilon$ & $1 \ldots$ & rV & IVד & VI & $1 \cdot \varepsilon$ & $r \varepsilon$ & المجموع \\
\hline
\end{tabular}

الرياضيات. وتحليل الأطر النظرية وأدبيات

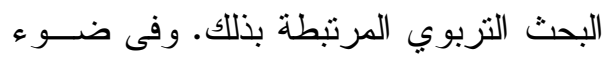
ذلك قام الباحث بإعداد قائمة بمهار ات القرن

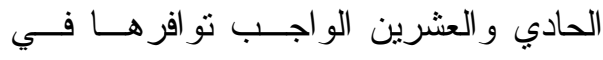
محتوى كتب الرياضيات بالمرحلة الابتندائيــة
بعد الاطلاع على مهــار ات القـرن

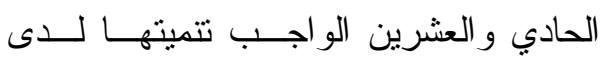
المتعلمين في المر احل الدراســـية المختلفـــة وبخاصة المرحلة الابتدائية، و التــي يجــبـ فئب تضمنيها فى المناهج الدر اسية وخاصة مناهج 
الابتدائية أو لارنباطها بالتـريس أكثــر مــن

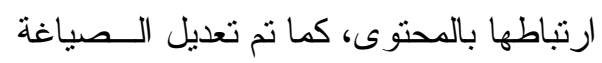

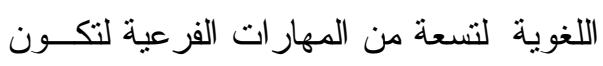

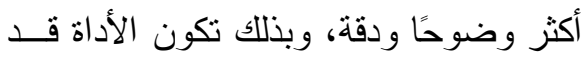

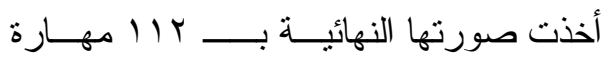
فر عية، نوزعت على أربع مهار ات رئيسة.

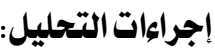
يعد تحليل المحتوى أسلوب بحــث منهجي يستخلم في تحليل المحتوى الظاهر أو المضمون الصحيح لمادة مـنـ المــواد بطريقة موضوعية منظمة، واعتمد الباحث في عملية التحليل على الإجراءات الآتية: 1. تحديد الهدف من التحليل: و المتمثل فى تحديد مستوى تضمين مهار ات القــــن ون الحادي و العشرين فى محتــوى كتــب مهنب الرياضيات في الصفوف من الأول إلى مئى مادئ السادس بالمرحلة الابتدائية.

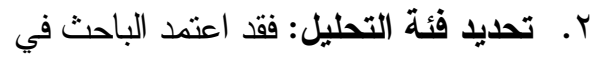

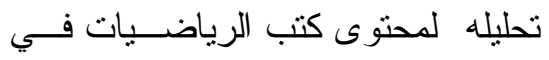

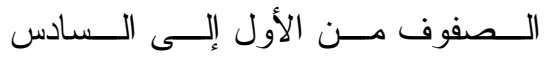
بالمرحلة الابتدائية الموضوع (عنــــان

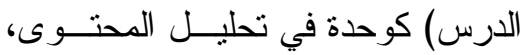
و الفقرة أو التمــرين كوحسـدة تـسجيل. ويقصد بالفقرة أنها جملة أو أكثر تعبــر عن فكرة و احدة. r. تحديد عينة التحليـل: وهــي جميــع الوحدات المتضمنة في كتب الرياضيات
وذللك بتحديد أربع مهار ات رئيسة، كل مهارة منها تتضمن عدد من المهـــار ات الفرعيــة المندرجة تحتها وتتنمي لنلاك المهارة الرئيسة و التي سيتم تحليل محتوى كتب الرياضـــات ونيات

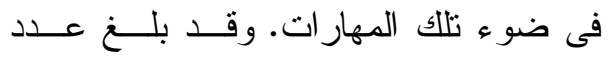
المهار ات الفرعية في الصورة الأوليــة لأداة البحث VII ا مهارة فرعية.

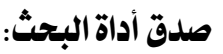
تعتمد معظم طــرق تقــدير حـساب الصدق على الأحكام التقييمية للمتخصــصنين في مجال أداة البحث، ومن ثم قــام الباحــث

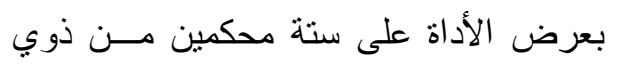
التخصص و الخبرة في تعلــيم الرياضـــيات وتعلمها و المهتمين بمهار ات القرن الحــادي و العشرين. وذللك بهدف معرفة ملاحظــاتهم

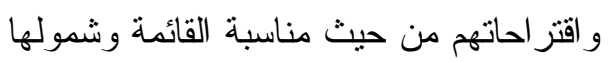

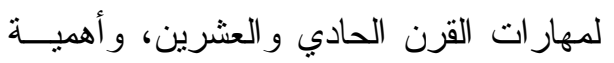
المهارات الرئيسة ومناسبتها لكل من مسادة

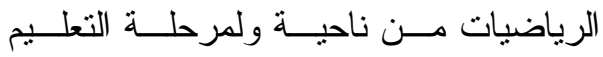
الابتدائي من ناحية أخرى، علاوة على تحديد مدى انتماء كل مهارة فرعية للمهارة الرئيسة

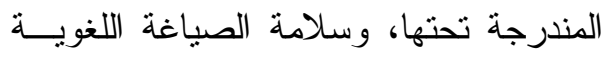
و العلمية ودقتها لكل مهارة فرعية. وتعديل ما لمان برونه سو اء بالحذف أو بالإضافة. وفي ضو ء ذللك قام الباحــث بــإجر اء التعديلات اللازمة و المتمثلة في: حذف خمس لـ مهار ات فرعية إما لعدم مناســبتها للمرحلـــة فئس 
- أجريت عملية التحليل لكل صــف مـن

صفوف المرحلة الابندائية على حدة.

- تمت قر اهة كل فقرة أو تمرين أو نشاط

متضمن بمحتوى الكتاب، وتحديد تتاولها

لأي مهارة فرعية من مهـــار ات القـــرن

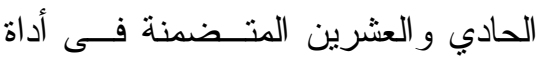

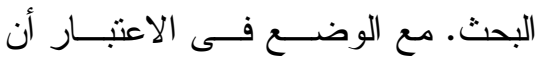

بعض الفقرات قد تتنمي لأكثر من مهارة

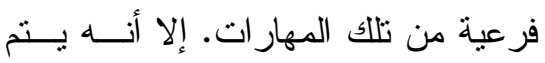

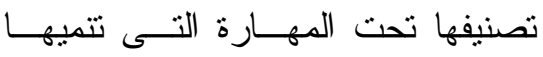

بصورة أساسية حتى لا يكـــون هنــاك

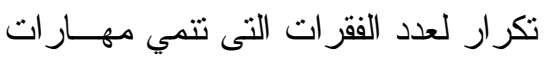

$$
\text { القرن الحادي و العشرين. }
$$

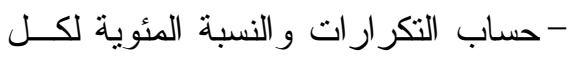

مهارة فرعية في كل كتاب للرياضــيات

المدرسية عينة الدراسة على حدة، ولكل فل على لرئل

$$
\text { صف در اسي. }
$$

ه. تحديد معيار الحكم على درجة تــوافر

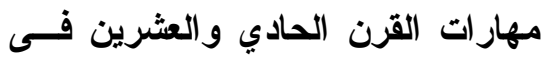
عينة الاراسة: و الذي تم تحديــده فــي

ضوء أدبيات تحليل المحتوى ثم عرضه ولنه

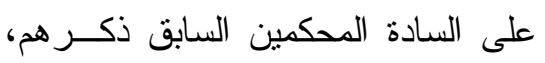
وقد نم التوصل للمعيار التالي: (أكثر من دمن

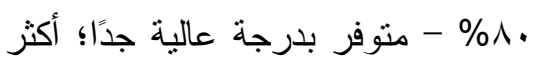

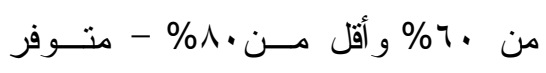

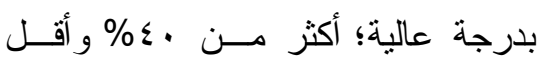

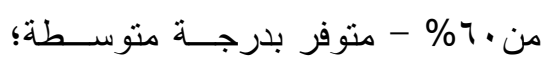

المدرسية المطورة في الــصفوف مــن

الأول إلى السادس بالمرحلة الابتدائيـــة بجمهورية مصر العربيــة فــي العـام

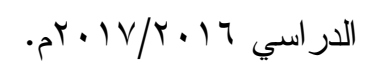

ـ. تحديـــ مجموعــة مــن العوامـلـل أو

الضوابط التى تحكم عمليــة التحليـلـل:

و المتمنتة فيما يلي

- يتم التحليل لمحتوى كتهـب الرياضـــات

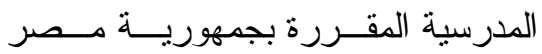

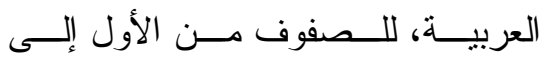

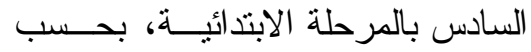

الطبعة التي أقرتها وزارة التربية و التعليم

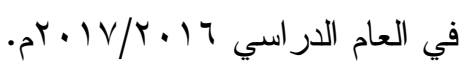

- انشتملت عملية التحليل على التـدريبات

و الأنشطة والأمنلة و التقييمات الموجودة

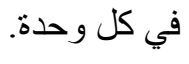

- تم اعتبار التمرين أو النشاط الرئيس وما

يحتويه من بنود فرعية وحــدة تحليـلـل

واحدة، حيث إنه يتضمن فكرة و احدة.

- تم التحليل فى إطار المحتوى الرياضـــي

فقط لكتب الرياضيات المدرسـية، مـــع

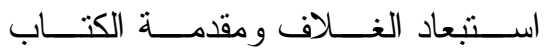

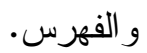

- لم تتثل عملية التحليل أدلة المعلم، أو أية نشر ات إرشادية مرفقة بكتاب الرياضيات

$$
\text { المدرسي. }
$$


نفسها بعد تعريفه بوحــــات التحليـلـل

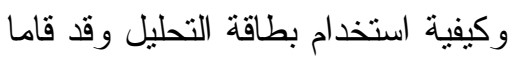
بالتحليل بشكل مستقل. ثم قام الباحث بحساب معامل ثبات التحليل باستخدام معادلة هولستي وذلك لعمليتي التحليل التي قام بها الباحث و التحليل التـاني

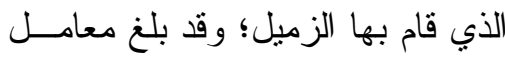
ثبات التحليل (r9\%). وتشير الدر اسات و الأدبيات التزبويـــة إلى أن معامل الثبات للاتفاق يكون مقبو لا إذا زاد عن (•^\%). لذلك تعد قيم معاملي ثبات التحليل التى حصل عليها الباحث بالطريقتين

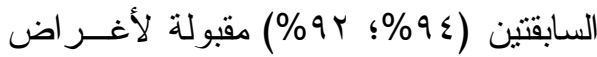
البحث مما يدعونا للاطمئنان و الوثنـوق فـى لـى ثبات النتائج التي سنحصل عليها من استخدام

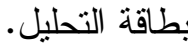

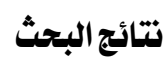

النتائج المتعلقة بالإجابة عن السؤال

الأول من أسئلة البحث و الذي ينص على: ما مهار ات القرن الحادي و العـشرين الواجـبـ تو افرها فى كتــب الرياضــيات المطــورة بالمرحلة الابتدائية فى مصر؟

تعد الإجابة عن هذا الــسؤال نقطـــة

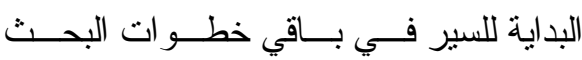
و إجر اءاتها؛ سعياً للوصول إلى قائمة مهار ات لون

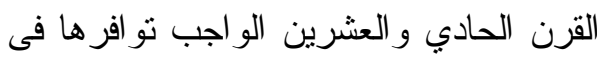
كتب الرياضيات المطورة بالمرحلة الابتدائية
أكثر من ·r\% و أقل من • ع\% - منوفر

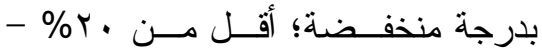
منوفر بدرجة منخفضة جدًا). • صدق أداة البحث

للتحقق من ثبات بطاقة تحليل محتوى

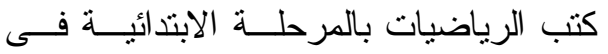
ضوء منظومة مهــار ات القـرن الحــادي و العشرين نم حســابها باســتخدام طــــيقتنين

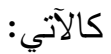

1. إعادة التحليل: قام الباحــث بتحليـل

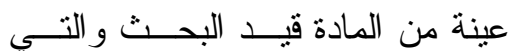

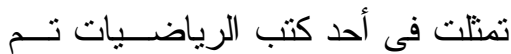

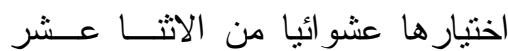
كتاب عينة البحث، وهو كتاب الصف

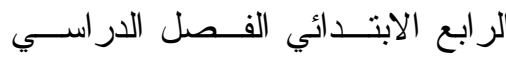
الثاني؛ ثم قام بتحليل الكتاب نفسه مرة

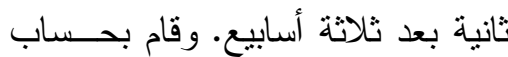
معامل الاتفاق بين التحليلين باستخدام معادلة هولستى التى بلغت (ع 9\%).

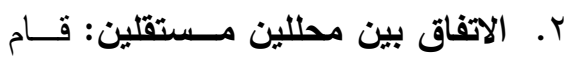
الباحث بتحليل كتاب أخر من عينــهـ

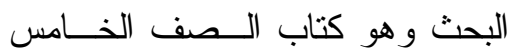
الفصل الدراسي الأول، وقام فى نفس

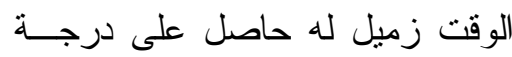
الدكتور اة فــي تخــصص المنـــاهج وطرق تدريس الرياضــيات بتحليـلـ الكتاب نفسه ومستخدما بطاقة التحليل 
ما درجة تو افر مهــار ات القـرن الحــادي

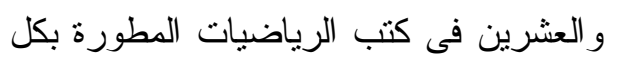
صف دراسي من صفوف المرحلة الابتدائية فى مصر؟ للإجابة عن السؤال الثانى تم تحليل محتــوى كتب الرياضيات المطورة بكل صف در اسي (فصل دراسى أول - فصل دراسي ثـاني)

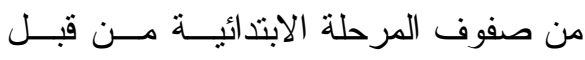

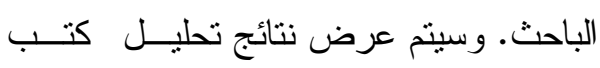
الرياضيات المطورة فى الصفوف من الأول

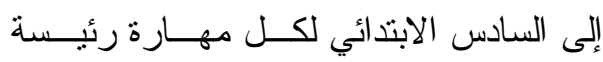
بقائمة مهار ات القرن الحادي و العشرين على الابنى

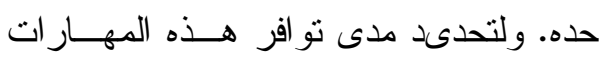

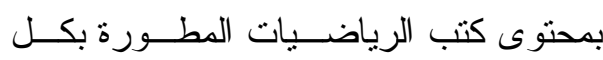
صف در اسي تم حساب تكر ار كـلـ مهــارة

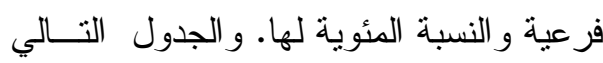
ىوضتح مدى تو افر مهار ات المحسـور الأول ولند

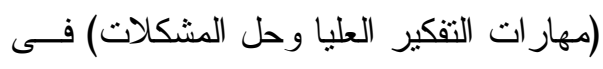
كتب الرياضيات المطورة بكل صف در اسي

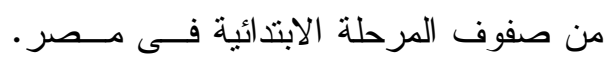

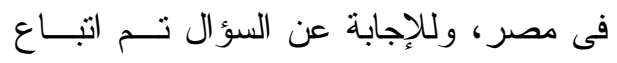

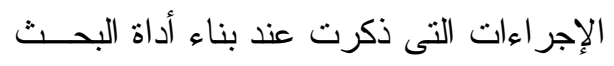

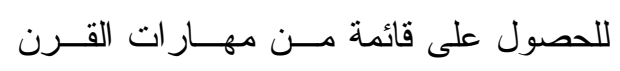

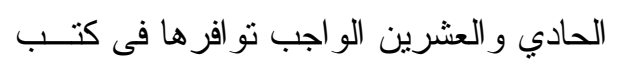

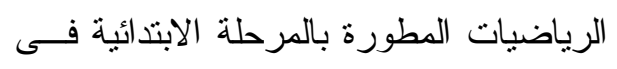

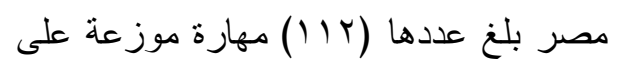
أربع مهار ات رئيسة. و الجدول التالي يوضح

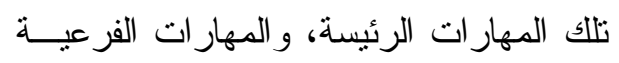
في كل منها. جدول (Y): توزيع المهارات الرئيسة بقائمة مهارات القرن الحادي و العشرين وعداد العهاري

\begin{tabular}{|c|c|c|}
\hline \multicolumn{3}{|c|}{ المهارات الفرعية في كل منها. } \\
\hline الفرعية & المهارة الرئيسة & p \\
\hline r. & مهار ات التفكير العليا وحل & 1 \\
\hline$r \varepsilon$ & مهار ات التعاون و التو اصل & r \\
\hline זr & مهار ات الحياة الاجتماعية & $r$ \\
\hline ro & مهارات التنتور المعرفي & $\varepsilon$ \\
\hline $11 \mathrm{r}$ & 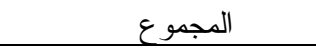 & \\
\hline
\end{tabular}

النتائج المتعلقة بالإجابة عن السؤال

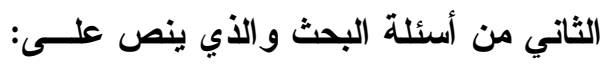


جدول (ץ): درجة تو افر مهار ات التفكير العليا وحل المشكلات فى كتب الرياضيات المطورة بكل

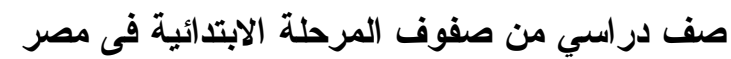

\begin{tabular}{|c|c|c|c|c|c|c|c|c|c|}
\hline المجموع & الصادس & الخامف & الصف & الثف & الثاني & الأصف & الفقرات & يتضمن المحتوي مناشط & p \\
\hline$r$. & $r$ & $\wedge$ & $\varepsilon$ & 1 & r & $r$ & العدد & \multirow{2}{*}{ 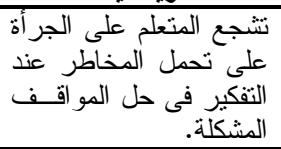 } & \multirow[t]{2}{*}{$T$} \\
\hline$\cdot, 01$ & $\cdot, \leq \varepsilon$ & $1, Y^{1}$ & אT, & $\cdot, 11$ & $\cdot, \varepsilon r$ & $\cdot, \varepsilon r$ & $\%$ & & \\
\hline$r$. & $\wedge$ & $r$ & $r$ & $r$ & $r$ & $r$ & العدد & \multirow{2}{*}{ 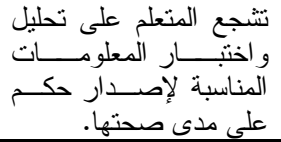 } & \multirow[t]{2}{*}{$T$} \\
\hline$\cdot, 01$ & $1,1 V$ & $\cdot, r_{1}$ & $\cdot, \leq 7$ & •,rV & צ & $\cdot, \varepsilon r$ & $\%$ & & \\
\hline$r$. & 0 & $\varepsilon$ & 1 & $\bar{r}$ & $r$ & 0 & العدد & \multirow{2}{*}{ 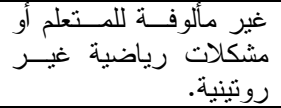 } & \multirow[t]{2}{*}{$r$} \\
\hline$\cdot, 01$ & $\cdot, V r$ & זד,. & $\cdot, 10$ & $\cdot, r V$ & $\cdot, T \leq$ & $1, \cdot \varepsilon$ & $\%$ & & \\
\hline $17 \varepsilon$ & $\varepsilon 9$ & $r \varepsilon$ & 11 & Tr & rt & $r \leq$ & العدد & \multirow{2}{*}{ 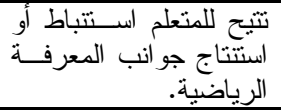 } & \multirow[t]{2}{*}{$\varepsilon$} \\
\hline$\varepsilon, V \varepsilon$ & $\mathrm{V}, \mathrm{IV}$ & $r, v V$ & $r, Y \wedge$ & $\varepsilon, 1 Y$ & $0,0 \leqslant$ & & $\%$ & & \\
\hline 9 & $\varepsilon$ & $r$ & 1 & 1 & 1 & . & العدد & \multirow{2}{*}{ 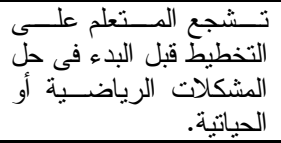 } & \multirow[t]{2}{*}{0} \\
\hline דצ', & $\cdot, 09$ & $\cdot, r)$ & $\cdot, 10$ & $\cdot, 1 \wedge$ & $\cdot, r_{1}$ & . & $\%$ & & \\
\hline$\varepsilon$ & $r$ & $r$ & $\dot{1}$ & $\cdot$ & $\cdot$ & $\cdot$ & العدد & \multirow{2}{*}{ تشجحع المتعلم على تحديد الرياضية بدقة. } & \multirow[t]{2}{*}{7} \\
\hline$\cdot, 1 Y$ &., 19 & $\cdot, r)$ & . & $\cdot$ & . & . & $\%$ & & \\
\hline 7 & $r$ & $\varepsilon$ & . & . & . & . & العدد & \multirow{2}{*}{ 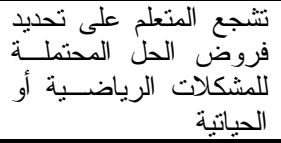 } & \multirow[t]{2}{*}{$\bar{V}$} \\
\hline.,$I V$ & $\cdot, r q$ & זד, & . & . & . & . & $\%$ & & \\
\hline$\varepsilon$ & . & $r$ & $r$ & - & . & . & العدد & \multirow{2}{*}{ 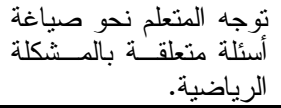 } & \multirow[t]{2}{*}{$\bar{\Lambda}$} \\
\hline ., & . & $\cdot, r)$ & , r & . & . & . & $\%$ & & \\
\hline • & · & . & · & · & · & · & العدد & \multirow{2}{*}{ 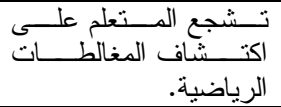 } & \multirow[t]{2}{*}{9} \\
\hline . & . & . & . & . & . & . & $\%$ & & \\
\hline 1 & . & . & . & . & 1 & . & العدد & \multirow{2}{*}{ وتثقيب منكاره المتعلم تصية. } & \multirow[t]{2}{*}{1.} \\
\hline$\cdot, \cdot r$ & . & . & . & $\cdot$ & $\cdot, Y_{I}$ & . & $\%$ & & \\
\hline . & . & . & . & . & . & . & العدد & \multirow{2}{*}{ 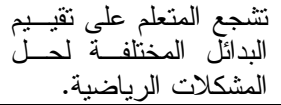 } & \multirow[t]{2}{*}{11} \\
\hline . & . & . & . & . & . & . & $\%$ & & \\
\hline 1 & . & . & . & . & . & 1 & العدد & \multirow{2}{*}{ 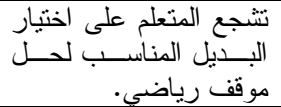 } & \multirow[t]{2}{*}{$I T$} \\
\hline$\cdot, \cdot r$ & . & . & . & . & . & $\cdot, Y_{1}$ & $\%$ & & \\
\hline$V$ & . & . & $r$ & 1 & $r$ & . & العدد & \multirow{2}{*}{ تطلب من الكبر عدد ممكن من البحن } & \multirow[t]{2}{*}{14} \\
\hline$\cdot, r \cdot$ & . & . & $\cdot, \leqslant 7$ & $\cdot, 1 \wedge$ & $\cdot, T \leq$ & . & $\%$ & & \\
\hline 0 & r & . & . & 1 & 1 & 1 & العدد & \multirow{2}{*}{ تطلب من النتائج التي تُعلم التحقل } & \multirow[t]{2}{*}{$1 \varepsilon$} \\
\hline$\cdot, 1 \leqslant$ & $\cdot, r q$ & • & $\cdot$ & $\cdot, 1 \wedge$ & 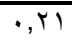 & $\cdot, \Gamma)$ & $\%$ & & \\
\hline
\end{tabular}




\begin{tabular}{|c|c|c|c|c|c|c|c|c|c|}
\hline المجموع & السادس & الخامس & الصف & الثفالث & الصانفي & الصف & الفقر ات & يتضمن المحتوي مناشط & p \\
\hline 001 & $1 \leqslant 1$ & 77 & $V_{T}$ & $\pi r$ & $\wedge \varepsilon$ & 71 & العدد & \multirow{2}{*}{ 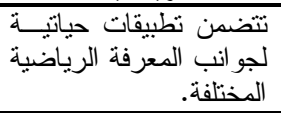 } & \multirow[t]{2}{*}{10} \\
\hline 17,11 & $Y, T V$ & $1 \cdot, \mathrm{r \Lambda}$ & $11, V r$ & rr,or & $|v, q|$ & $\mid r, 71$ & $\%$ & & \\
\hline 19 & 7 & $r$ & $\varepsilon$ & $r$ & $r$ & 1 & العدد & \multirow{2}{*}{ تلتضاية. مشكلات مفتوحة } & \multirow[t]{2}{*}{17} \\
\hline., 00 & $\cdot, \wedge \wedge$ & $\cdot, \varepsilon V$ & $\cdot, \bar{r}$ & $\cdot, r \mathrm{~V}$ & $\cdot, 7 \varepsilon$ & 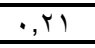 & $\%$ & & \\
\hline $1 \pi$ & $r$ & $r$ & $r$ & $r$ & $r$ & $r$ & العدد & \multirow{2}{*}{ تتضنمن مشكلات لها أكثر } & \multirow[t]{2}{*}{ IV } \\
\hline$\cdot, \mathrm{r} \wedge$ & $\cdot, r 9$ & $\cdot, r)$ & $\cdot, r$, & $\cdot, r V$ & $\cdot, 7 \varepsilon$ & $\theta, \sum Y$ & $\%$ & & \\
\hline $1 \pi$ & $\varepsilon$ & $r$ & 1 & $r$ & $r$ & 1 & العدد & \multirow{2}{*}{ 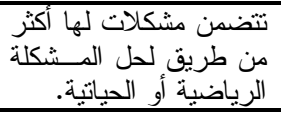 } & \multirow[t]{2}{*}{11} \\
\hline$\cdot, \Gamma \wedge$ & $\cdot, 09$ & $\cdot, \sum V$ & $\cdot, 10$ & $\cdot, r V$ & $\cdot, \varepsilon \Gamma$ & $\cdot, r)$ & $\%$ & & \\
\hline$\dot{1}$ & $\cdot$ & . & $\dot{1}$ & $\cdot$ & $\dot{1}$ & $\cdot$ & العدد & \multirow{2}{*}{ 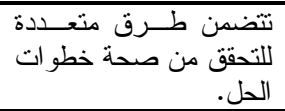 } & \multirow[t]{2}{*}{19} \\
\hline · & . & . & • & . & . & · & $\%$ & & \\
\hline 0 & 1 & $r$ & 1 & $\cdot$ & $\cdot$ & $\cdot$ & العدد & \multirow{2}{*}{ 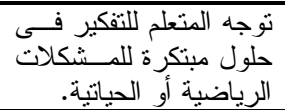 } & \multirow[t]{2}{*}{$r}$. \\
\hline$\cdot, 1 \leqslant$ & $\cdot, 10$ & $\cdot, \leqslant V$ & $\cdot, 10$ & . & · & · & $\%$ & & \\
\hline 19 & 7 & $\mathrm{~V}$ & $r$ & 1 & 1 & $r$ & العدد & \multirow{2}{*}{ تتبرير ات منطقية لحلموله. } & \multirow[t]{2}{*}{ YI } \\
\hline., 00 & $\cdot, \wedge \wedge$ & $1,1$. & $\cdot, \mu$ & $\cdot, 1 \wedge$ & $\cdot, Y_{1}$ & $\cdot, \varepsilon Y$ & $\%$ & & \\
\hline . & · & . & . & . & . & . & العدد & \multirow{2}{*}{ 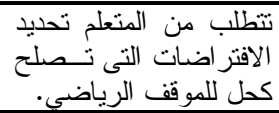 } & \multirow[t]{2}{*}{$\overline{Y r}$} \\
\hline · & • & · & · & · & • & • & $\%$ & & \\
\hline . & . & · & · & · & · & . & العدد & \multirow{2}{*}{ 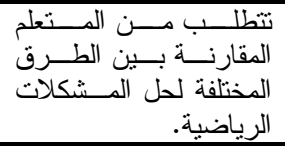 } & \multirow[t]{2}{*}{$r T$} \\
\hline · & . & . & . & . & . & . & $\%$ & & \\
\hline r & . & . & r & . & . & . & العدد & \multirow{2}{*}{ 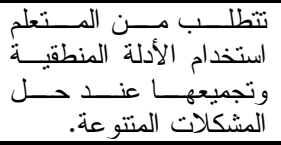 } & \multirow[t]{2}{*}{$r \varepsilon$} \\
\hline$\cdot, \cdot 7$ & . & . & $\cdot, \mu$ & . & . & . & $\%$ & & \\
\hline . & . & $\cdot$ & $\cdot$ & $\cdot$ & $\dot{.}$ & $\cdot$ & العدد & \multirow{2}{*}{ 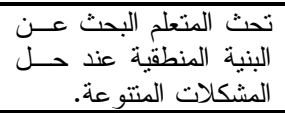 } & \multirow[t]{2}{*}{ ro } \\
\hline . & . & . & . & . & . & . & $\%$ & & \\
\hline 1. & $\varepsilon$ & 7 & $\dot{ }$ & $\dot{.}$ & . & $\dot{ }$ & العدد & \multirow{2}{*}{ 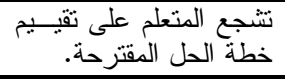 } & \multirow[t]{2}{*}{$r T$} \\
\hline$\cdot, 19$ &., 09 & $\cdot, 9 \leq$ & $\cdot$ & . & $\cdot$ & $\cdot$ & $\%$ & & \\
\hline$r \varepsilon$ & 9 & $\wedge$ & 0 & 7 & $\varepsilon$ & r & العدد & \multirow{2}{*}{ 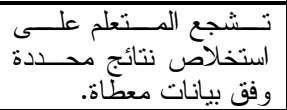 } & \multirow[t]{2}{*}{$T V$} \\
\hline$\cdot, 91$ & $1, \pi$ & $1, Y_{7}$ & $\cdot, \mathrm{VV}$ & $1,1$. & $\cdot, 10$ & $\cdot, \varepsilon r$ & $\%$ & & \\
\hline 9 & $r$ & $\varepsilon$ & $r$ & • & . & - & العدد & \multirow{2}{*}{ 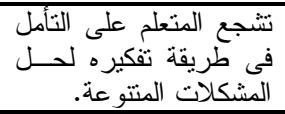 } & $r \wedge$ \\
\hline •,YT & $\cdot, \leq \leqslant$ & זד, • & $\cdot, \mu$ & . & . & . & $\%$ & & \\
\hline$r \varepsilon$ & 7 & $\wedge$ & 9 & V & $\varepsilon$ & . & العدد & 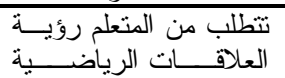 & $r q$ \\
\hline$\cdot, 9 \wedge$ & $\cdot, \wedge \wedge$ & $1, Y_{7}$ & $1, r q$ & $1, r \wedge$ & $\cdot, \wedge 0$ & . & $\%$ & و والضنمنية بينهات الــصريحة & \\
\hline 9 & $r$ & $\varepsilon$ & $r$ & $\cdot$ & . & . & العدد & 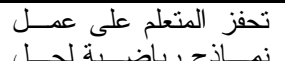 & $r$. \\
\hline$\cdot, Y_{T}$ & $\cdot, \Sigma \varepsilon$ & שזד, & $\cdot, r$ & . & . & - & $\%$ & المشكلآت الحياتية. & \\
\hline 9117 & TTV & 174 & $1 \pi \lambda$ & $I V \varepsilon$ & $1 \leqslant 1$ & $1 \cdot \varepsilon$ & العدد & & \\
\hline$r \wedge, \Sigma\rangle$ & $r 9, .9$ & $r_{0, \Sigma V}$ & $r, r$. & $\Gamma 1, \wedge \mathrm{V}$ & $r \cdot, \cdot T$ & $r 1, \pi r$ & $\%$ & & \\
\hline
\end{tabular}


الطـــرق المختلفـــة لحــلـ المــشكلات الرياضية؛ أو تحثثه على البحــث عـنـ

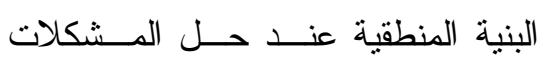

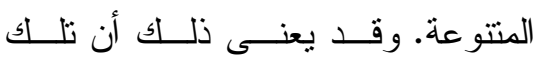
المهار ات الفرعية - رغم أهميتها - من ون دان

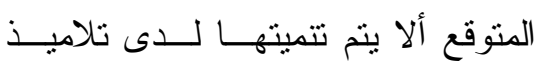
المرحلة الابتدائية لعدم مرور هم بخبر التين

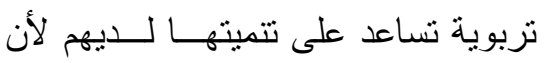

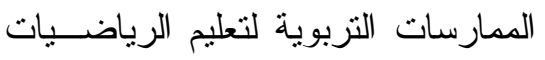
وتعلمها تتأثز بشكل كبير بما يت ضندنه

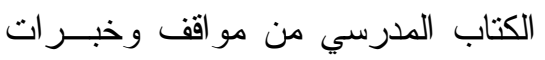
تزبوية. - وجود اهتمام - بدرجة مقبولـــة - فــي كتب الرياضـيات المدرسـية بــبعض المهارات الفرعيــة المندرجــة تحــت مهار ات التفكير العليا وحل المـشكلات مثلك: وجود مناثط رياضــية تتـضن تطبيقــات حياتيـــة لجو انـــب المعرفـــة الرياضــية المختلفــة؛ وتتــيح للمـتـعلم استتباط أو استتناج جوانــب المعرفـــة الرياضية. وقد يعزى ذلك إلى اهتمــام

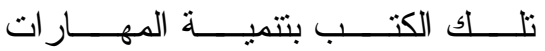
و الخوارزميات الرياضية لدى الطــلاب من جانب علاوة على اهتمامها بتقــديم مواقف رياضية ومهام تتضمن تطبيقات

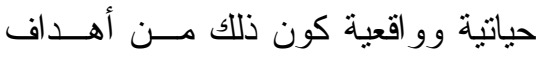

تظهر نتائج التحليل لكتب الرياضيات المدرسية في الـصفوف مــن الأول حتـى تصى

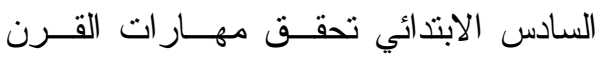
الحادي و العشرين فيما يتعلق بالمحور الأول بـاتي

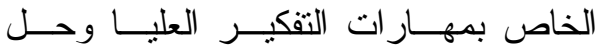

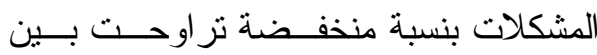

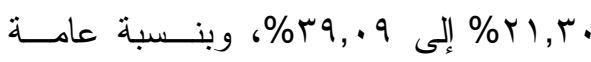

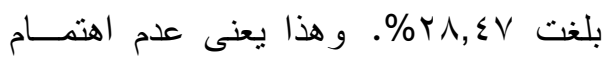
تلك الكتب بتضمين مو اقف رياضية تهـدف

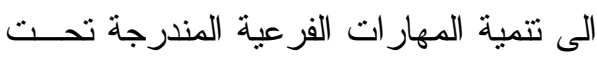

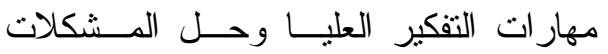
باعتبار ها واحدة من مهار ات القرن الحـادي

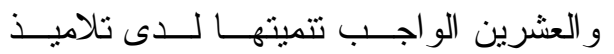

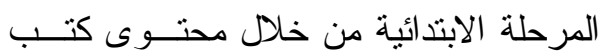
الرياضيات المدرسية.

وتكثف نتائج التحليل عددًا من النقاط يمكن تلخيص أبرزها فيما يلي:

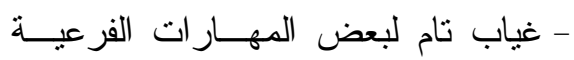

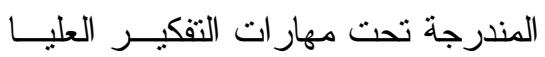
وحل المشكلات منل : تـشجيع المــتعلم على اكتثاف المغالطات الرياضـــية؛ أو تقييم البدائل المختلفة لحـل المـشكلات الرياضية، أو وجود مناثـــ رياضــية تتضمن طرق متعددة للتحقق من صحة خطوات الحل، وتتطلب مــن المــتعلم

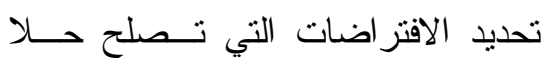
للموقف الرياضـــــ أو المقارنـــة بــين 
و الخامس و السادس - الاهنمام بهـــا وان

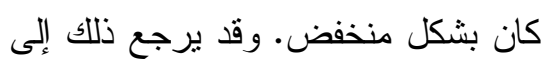

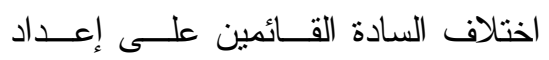
وتأليف تلالك الكتب واختلاف توجهـاتهم الفكرية و التربوية مما أدى بطبيعة الحال

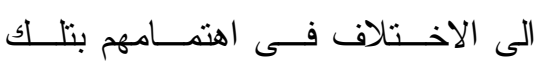

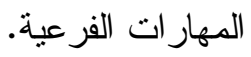
و استكمالا للإجابة عن السؤال الثــاني من أسئلة البحث تم حساب تكرار كل مهارة

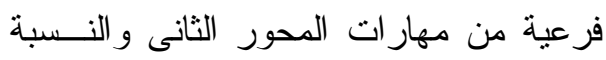
المئوية لها. و الجدول التالي عوضنح مهـدى مهى

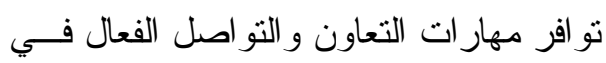
كتب الرياضيات المطورة بكل صف درات اسي من صفوف المرحلة الابتدائية فى مصر. بكل صني
تصميم مناهج الرياضيات المدرسية وفق

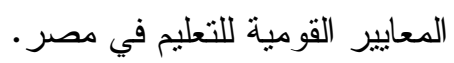
- تختلف نسب اهتمام كتهـب الرياضــيات

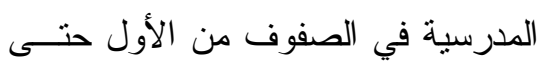

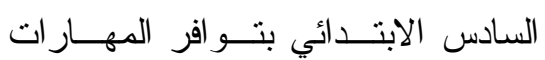
الفرعية المندرجة تحت مهار ات التفكير

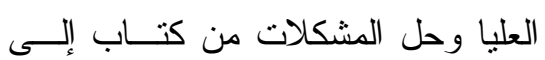
آخر : حيث نجد في بعض الكتب تختفي منها تماما بعض تلك المهارات الفرعية

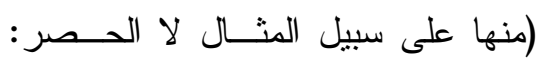

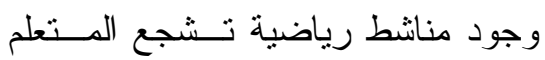

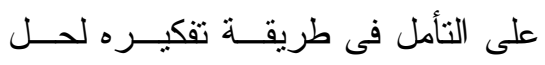

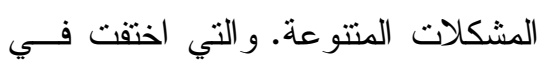

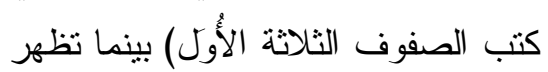

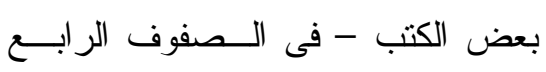


جدول (؛ ): درجة تو افر مهارات التعاون والتواصل الفعال في كتب الرياضيات المطورة بكل

\begin{tabular}{|c|c|c|c|c|c|c|c|c|c|}
\hline المجموع & السادف & الخامس & الصف & الثالث & الثاني & الصف & الفقرات & يتضاشط رياضية المحتوى & p \\
\hline 0 & $\varepsilon$ & . & 1 & . & . & . & العدد & \multirow{2}{*}{ تلغة رياضية المتعلم التحــدثة. } & \multirow[t]{2}{*}{1} \\
\hline$\cdot, 1 \leq$ & $\cdot, 09$ & . & $\cdot, 10$ & . & . & . & $\%$ & & \\
\hline . & . & . & . & . & . & . & العدد & \multirow{2}{*}{ 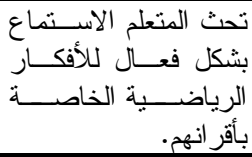 } & \multirow[t]{2}{*}{$r$} \\
\hline - & . & . & . & . & . & . & $\%$ & & \\
\hline . & . & . & . & . & . & . & العدد & \multirow{2}{*}{ 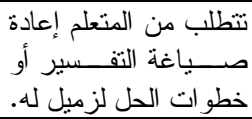 } & \multirow[t]{2}{*}{$r$} \\
\hline - & . & . & . & . & . & . & $\%$ & & \\
\hline . & . & . & . & . & . & • & العدد & \multirow{2}{*}{ 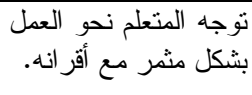 } & \multirow[t]{2}{*}{$\varepsilon$} \\
\hline . & . & . & . & . & . & . & $\%$ & & \\
\hline . & . & . & . & . & . & . & العدد & \multirow{2}{*}{ 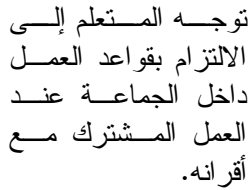 } & \multirow[t]{2}{*}{0} \\
\hline . & . & . & . & . & . & . & $\%$ & & \\
\hline 7 & r & $r$ & . & . & 1 & . & العدد & \multirow{2}{*}{ 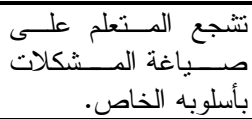 } & \multirow[t]{2}{*}{7} \\
\hline$\cdot, I V$ & $\cdot, Y 9$ & $\cdot, \leqslant V$ & . & . & $\cdot, Y)$ & . & $\%$ & & \\
\hline 1 & . & 1 & . & . & . & . & العدد & \multirow{2}{*}{ التحفز المتعلم على العمل الجماعي. } & \multirow[t]{2}{*}{$\mathrm{V}$} \\
\hline$\cdot, \cdot r$ & . & .17 & . & . & . & . & $\%$ & & \\
\hline 9 & $r$ & 7 & . & . & . & . & العدد & \multirow{2}{*}{ 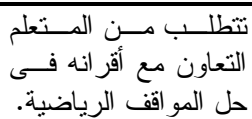 } & \multirow[t]{2}{*}{$\widehat{\Lambda}$} \\
\hline$\cdot, Y T$ & $\cdot, \leqslant \leqslant$ & $\cdot, 9 \leqslant$ & . & . & . & . & $\%$ & & \\
\hline 19 & V & $\varepsilon$ & 7 & 1 & 1 & . & العدد & \multirow{2}{*}{ 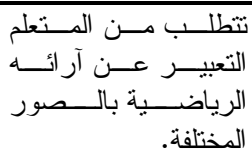 } & \multirow[t]{2}{*}{9} \\
\hline., 00 & $1, \cdot r$ & אוד, & $\cdot, 94$ & $\cdot, 11$ & $\cdot, Y_{1}$ & . & $\%$ & & \\
\hline 19 & $\varepsilon$ & $\mathrm{V}$ & $\varepsilon$ & $r$ & $r$ & . & العدد & \multirow{2}{*}{ 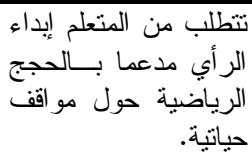 } & \multirow[t]{2}{*}{1.} \\
\hline$\cdot, 00$ & $\cdot, 09$ & $1,1$. & $\cdot, T Y$ & $\cdot, r V$ & $\cdot, \varepsilon r$ & . & $\%$ & & \\
\hline 7 & . & $r$ & $\varepsilon$ & . & . & . & العدد & \multirow{2}{*}{ 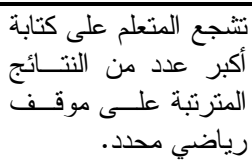 } & \multirow[t]{2}{*}{11} \\
\hline$\cdot, I V$ & . & $\cdot, r)$ & r & . & . & . & $\%$ & & \\
\hline$r$ & . & r & . & $\cdot$ & . & $\cdot$ & العدد & \multirow{2}{*}{ 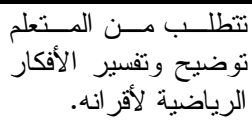 } & \multirow[t]{2}{*}{ IT } \\
\hline., .7 & . & $\cdot, r$ & . & . & . & . & $\%$ & & \\
\hline
\end{tabular}




\begin{tabular}{|c|c|c|c|c|c|c|c|c|c|}
\hline المجموع & الصادس الصف & الخامس & الصف الصابع & الصفالث & الصف الثاني & الأول & الفقرات & يتضنمن المحتوى & م \\
\hline . & . & . & . & . & . & . & العدد & \multirow{2}{*}{ 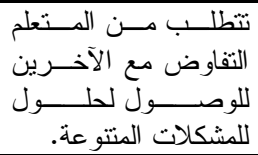 } & \multirow[t]{2}{*}{$\pi$} \\
\hline . & . & . & . & . & • & • & $\%$ & & \\
\hline . & • & • & • & . & • & • & العدد & \multirow{2}{*}{ 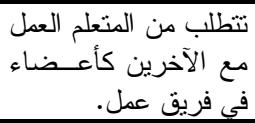 } & \multirow[t]{2}{*}{18} \\
\hline • & · & . & . & · & . & . & $\%$ & & \\
\hline 19 & 9 & $r$ & 7 & 1 & . & . & العدد & \multirow{2}{*}{ أو تخليفات مو اقف رياضية لاضية } & \multirow[t]{2}{*}{10} \\
\hline., 00 & I, & $\cdot, \leqslant V$ & $\cdot, 94$ & $\cdot, 11$ & . & . & $\%$ & & \\
\hline roq & $\leqslant 0$ & Vr & $0 \leq$ & or & YI & $1 \varepsilon$ & العدد & \multirow{2}{*}{ 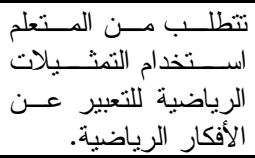 } & \multirow[t]{2}{*}{17} \\
\hline$\vee, \Sigma \wedge$ & 7,09 & $11, \Sigma \wedge$ & A,r & $9,0 Y$ & $\varepsilon, \varepsilon \wedge$ & $r, q 1$ & $\%$ & & \\
\hline V & . & $r$ & 1 & $\varepsilon$ & . & . & العدد & \multirow{2}{*}{ 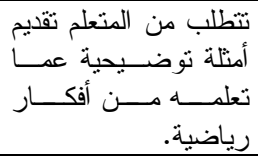 } & \multirow[t]{2}{*}{ iv } \\
\hline$\cdot, r \cdot$ & . & $\cdot, \mu$ &., 10 & $\cdot, V T$ & . & . & $\%$ & & \\
\hline$\varepsilon$ & . & $\varepsilon$ & . & . & . & . & العدد & \multirow{2}{*}{ 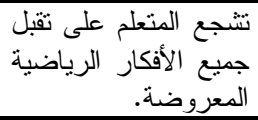 } & \multirow[t]{2}{*}{11} \\
\hline., 14 & . & י & . & . & . & $\cdot$ & $\%$ & & \\
\hline$\varepsilon$ & . & $\varepsilon$ & . & . & . & - & العدد & \multirow{2}{*}{ 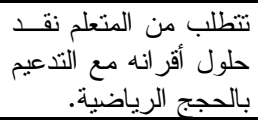 } & \multirow[t]{2}{*}{19} \\
\hline$\cdot, 1 r$ & • & יד & . & . & . & . & $\%$ & & \\
\hline . & . & . & . & . & . & . & العدد & \multirow{2}{*}{ 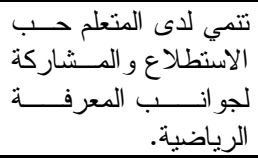 } & \multirow[t]{2}{*}{$r}$. \\
\hline . & . & . & . & . & • & . & $\%$ & & \\
\hline • & • & . & • & · & . & . & العدد & \multirow{2}{*}{ تثير دافعية المتعلم لتعلم } & \multirow[t]{2}{*}{$r$} \\
\hline . & . & . & . & . & . & . & $\%$ & & \\
\hline 1. & . & $\varepsilon$ & $r$ & $r$ & $\cdot$ & $\cdot$ & العدد & \multirow{2}{*}{ 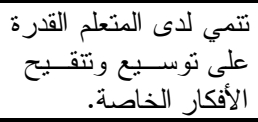 } & \multirow[t]{2}{*}{ rY } \\
\hline$\cdot, r q$ & . & . & $\cdot, \leqslant 7$ & $\cdot, 00$ & . & . & $\%$ & & \\
\hline . & . & . & . & . & . & . & العدد & \multirow{2}{*}{ 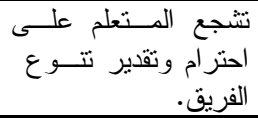 } & \multirow[t]{2}{*}{ Tr } \\
\hline . & . & - & . & . & . & . & $\%$ & & \\
\hline 11 & r & 7 & . & r & 1 & - & العدد & \multirow{2}{*}{ 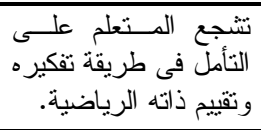 } & \multirow[t]{2}{*}{$r \varepsilon$} \\
\hline • & $\cdot, r q$ & $\cdot, 9 \leq$ & . & $\cdot, r V$ & $\cdot, Y I$ & . & $\%$ & & \\
\hline rNI & $V 7$ & $|r|$ & 19 & 70 & rT & $1 \varepsilon$ & العدد & \multirow[t]{2}{*}{ المجموع } & \\
\hline $11, \ldots$ & $11,1 \pi$ & $19, \cdot r$ & 14,19 & $11,9$. & $0,0 \leqslant$ & $r, q 1$ & $\%$ & & \\
\hline
\end{tabular}


وجود مناشط رياضية تتطلب من المتعلم

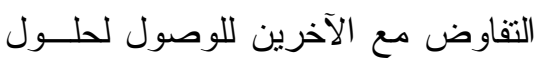

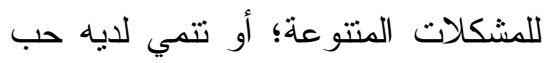

الاستطلاع و المشاركة لجوانب المعرفة

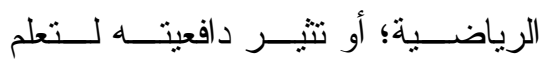

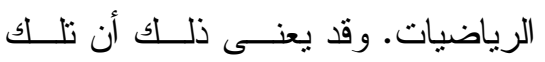

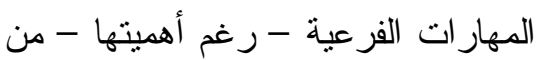

المتوقع ألا يتم تتميتها لدى المتعلمين في

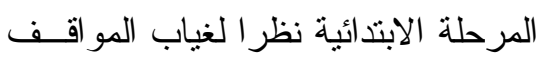

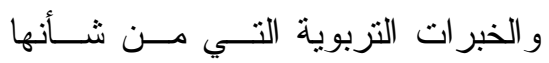

المـسـاعدة علــى تتمينهــــا لــديهم لأن

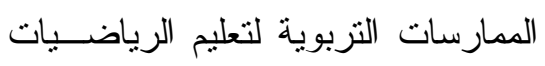

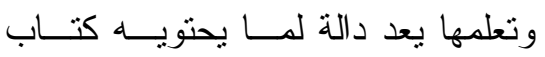

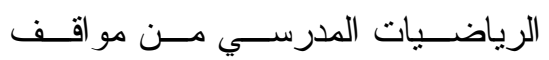

وخبرات تربوية. وذللك على الرغم من من مون

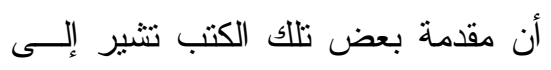

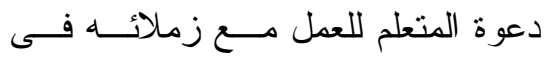

المهام الرياضية ليتعرف على أفكـار هم

$$
\text { الرياضية ويتو اصل معهم. }
$$

- وجود اهتمام - بدرجة مقبولــة - فـــي

كتب الرياضــيات المدرســية بمهــارة

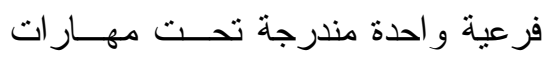

التعاون و التو اصل الفعال و المتمثلة فــي مني وجود مناشط رياضية تتطلب من المتعلم

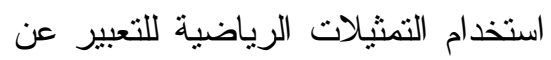
الأفكار الرياضية. وقد يفسر ذلك اهتمام

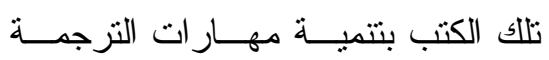

تظهر نتائج التحليل لكتب الرياضيات

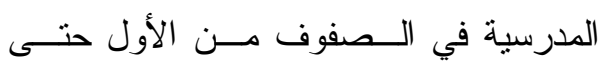

السـادس الابتدائي تحقــق مهـــار ات القــرن

الحادي و العشرين فيما يتعلق بالمحور الثاني

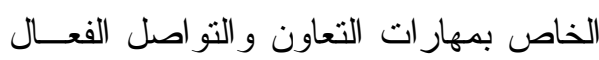

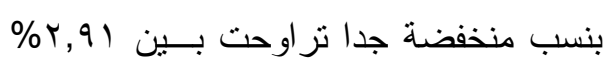

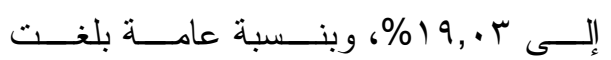

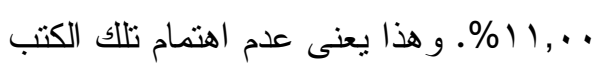

بتضمين مو اقف رياضية تهدف إلــى تتميـــة

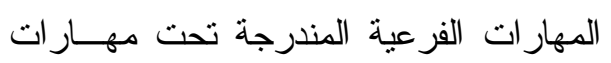

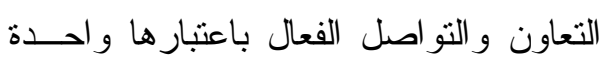

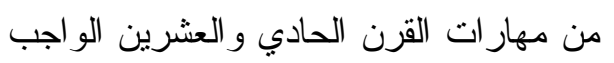

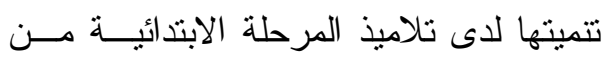

خلال محتوى كتب الرياضيات المدرسية.

وتكثف نتائج التحليل عددًا من النقاط يمكن تلخيص أبرزها فيما يلي:

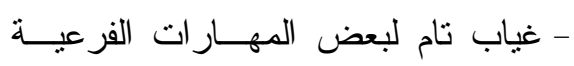

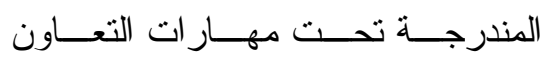

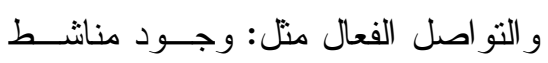

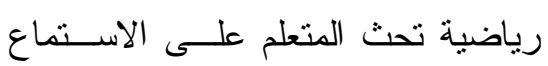

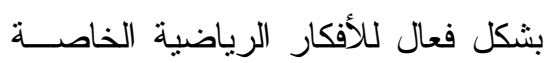

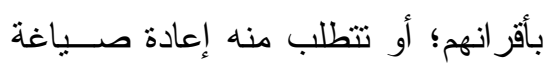

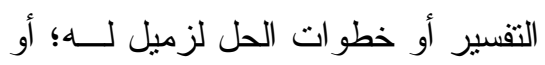

توجهه نحو العمل بشكل مثمر مع أقرانه

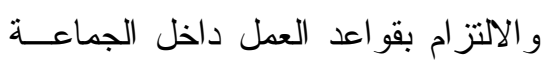

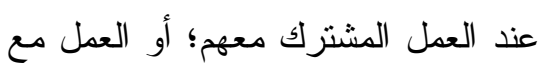

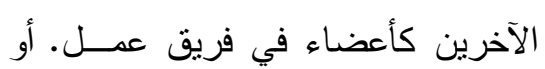




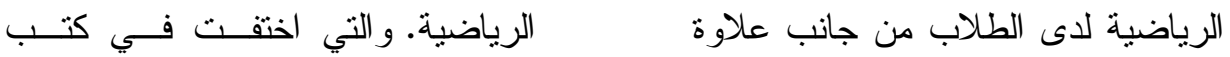

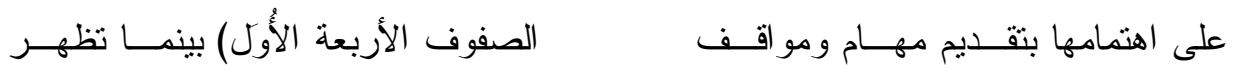

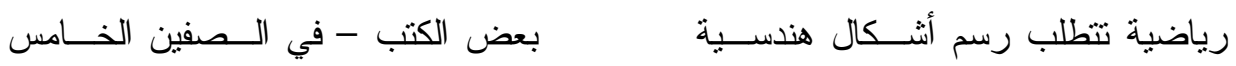

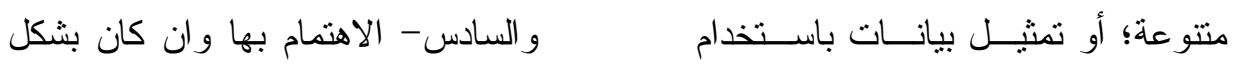

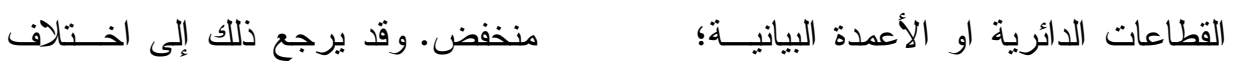

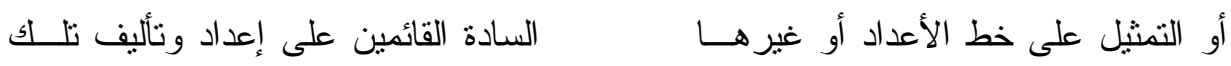

$$
\begin{aligned}
& \text { من المهام الرياضية وذلك لأنها تعد من }
\end{aligned}
$$

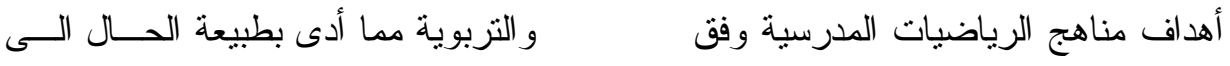

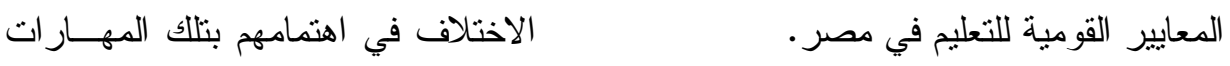

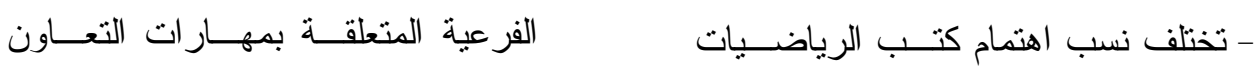

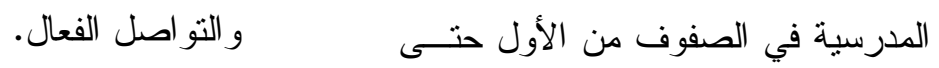

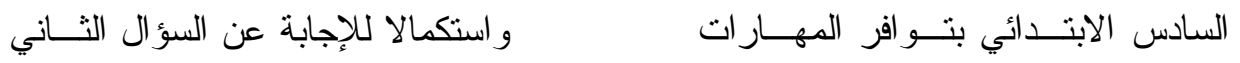

$$
\begin{aligned}
& \text { الفرعية المندرجة تحت مهار ات التعاون من أسئلة البحث تم حساب تكرار كل مهارة }
\end{aligned}
$$

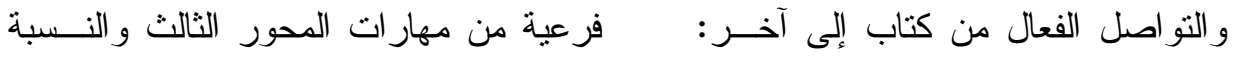

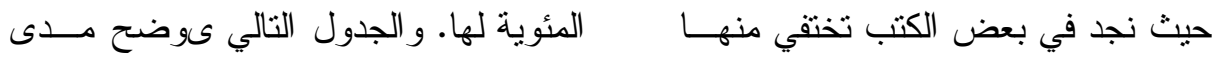

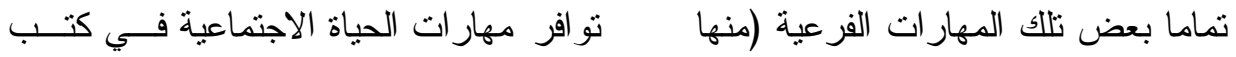

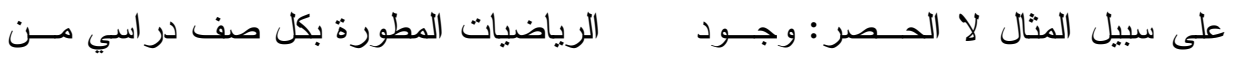

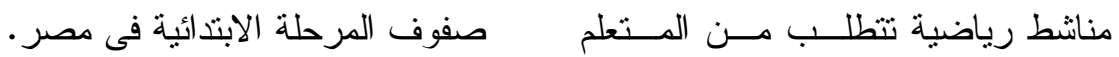

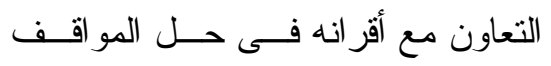


جدول (•): درجة تو افر مهارات الحياة الاجتماعية في كتب الرياضيات المطورة بكل صف

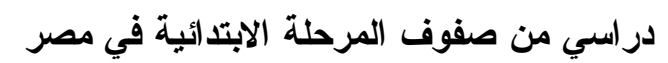

\begin{tabular}{|c|c|c|c|c|c|c|c|c|c|}
\hline المجموع & السادس & الخامس & الصف & الثاثث & الصفاني & الأصف & الفقر ات & يتضمن المحتوي مناشط & p \\
\hline . & . & . & . & . & . & . & العدد & \multirow{2}{*}{ 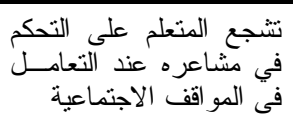 } & \multirow[t]{2}{*}{1} \\
\hline$\cdot$ & · & . & . & . & . & . & $\%$ & & \\
\hline . & . & . & . & . & . & . & العدد & \multirow{2}{*}{ 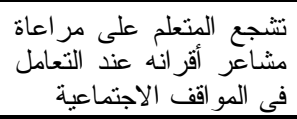 } & \multirow[t]{2}{*}{$r$} \\
\hline . & . & . & . & . & . & . & $\%$ & & \\
\hline . & . & . & . & . & . & . & العدد & \multirow{2}{*}{ 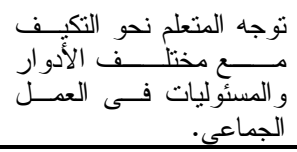 } & \multirow[t]{2}{*}{$r$} \\
\hline . & . & . & . & . & . & & $\%$ & & \\
\hline . & . & . & . & . & . & . & العدد & \multirow{2}{*}{ 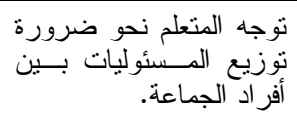 } & \multirow[t]{2}{*}{$\varepsilon$} \\
\hline . & . & . & . & . & . & . & $\%$ & & \\
\hline · & · & · & . & . & · & . & العدد & \multirow{2}{*}{ 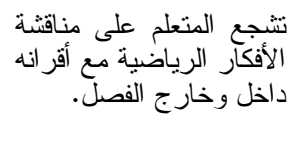 } & \multirow[t]{2}{*}{0} \\
\hline . & . & . & . & . & . & . & $\%$ & & \\
\hline. &. &. & . &. &. &. & العدد & \multirow{2}{*}{ 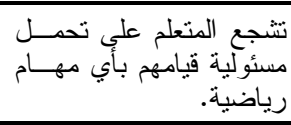 } & \multirow[t]{2}{*}{7} \\
\hline · & . & - & . & . & · & . & $\%$ & & \\
\hline . & . & . & . & - & . & · & العدد & \multirow{2}{*}{ 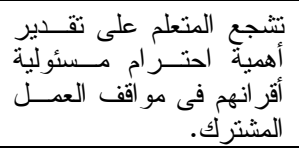 } & \multirow[t]{2}{*}{$\bar{v}$} \\
\hline . & . & . & . & . & . & . & $\%$ & & \\
\hline . & . & . & . & . & . & . & العدد & \multirow{2}{*}{ 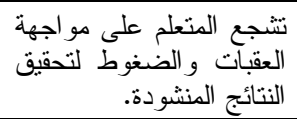 } & \multirow{2}{*}{$\wedge$} \\
\hline · & · & . & . & . & · & - & $\%$ & & \\
\hline . & . & . & . & . & . & . & العدد & \multirow{2}{*}{ 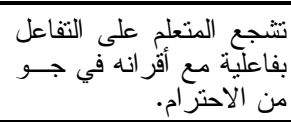 } & \multirow[t]{2}{*}{9} \\
\hline · & . & . & . & . & . & . & $\%$ & & \\
\hline$\varepsilon$ & 1 & 1 & . & . & 1 & 1 & العدد & \multirow{2}{*}{ 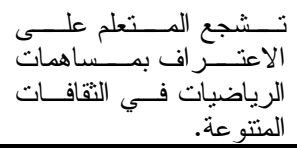 } & \multirow[t]{2}{*}{1.} \\
\hline$\cdot, 1 \mathrm{r}$ & $\cdot, 10$ & .17 & . & . & $\cdot, Y_{1}$ & $\cdot r^{\prime}$ & $\%$ & & \\
\hline 0 & 1 & 1 & . & . & $r$ & 1 & العدد & \multirow{2}{*}{ كيفية التخافِ المتعلم على الرياضيات معرفة } & \multirow[t]{2}{*}{11} \\
\hline$\cdot, 1 \leq$ & $\cdot, 10$ & .17 & . & . & r & $\cdot, r_{l}$ & $\%$ & & \\
\hline 0 & 1 & r & . & r & . & . & العدد & \multirow{2}{*}{ 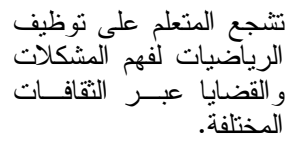 } & \multirow[t]{2}{*}{ Ir } \\
\hline$\cdot, 1 \leq$ & $\cdot, 10$ & $\cdot, r)$ & . & $\cdot, r V$ & . & · & $\%$ & & \\
\hline
\end{tabular}




\begin{tabular}{|c|c|c|c|c|c|c|c|c|c|}
\hline المجموع & الصفادس & الخامس & الصف & الثف & الصف & الصأول & الفقرات & يتضمن المحتوي مناثط & م \\
\hline - & • & • & . & • & . & · & العدد & \multirow{2}{*}{ 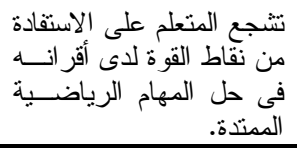 } & \multirow[t]{2}{*}{ ir } \\
\hline · & · & . & . & . & · & . & $\%$ & & \\
\hline . & . & . & . & . & . & . & العدد & \multirow{2}{*}{ 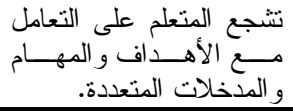 } & \multirow[t]{2}{*}{$1 \varepsilon$} \\
\hline . & . & . & . & . & . & . & $\%$ & & \\
\hline . & . & . & . & . & . & . & العدد & \multirow{2}{*}{ 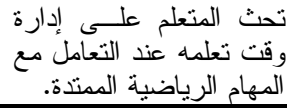 } & \multirow[t]{2}{*}{10} \\
\hline . & . & . & . & . & . & . & $\%$ & & \\
\hline . & . & . & . & . & . & . & العدد & \multirow{2}{*}{ 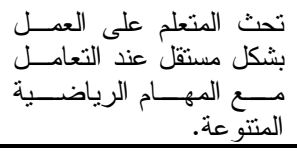 } & \multirow[t]{2}{*}{17} \\
\hline • & • & · & . & • & • & · & $\%$ & & \\
\hline . & . & . & . & . & . &. & العدد & \multirow{2}{*}{ 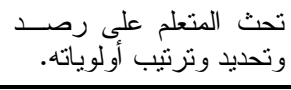 } & \multirow[t]{2}{*}{ IV } \\
\hline . & . & . & . & . & . & . & $\%$ & & \\
\hline . & . & . & . & . & . & . & العدد & \multirow{2}{*}{ 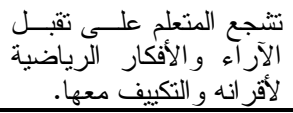 } & \multirow[t]{2}{*}{11} \\
\hline . & . & . & . & . & . & . & $\%$ & & \\
\hline TY & 0 & $\wedge$ & 7 & $\varepsilon$ & r & 1 & العدد & \multirow{2}{*}{ 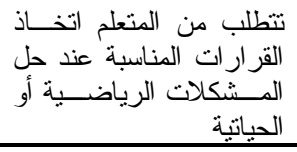 } & \multirow[t]{2}{*}{19} \\
\hline$\cdot, V_{0}$ & $\cdot, V \Gamma$ & $1, r 4$ & .,9ז & $\cdot, V r$ & $\cdot, \leqslant \Gamma$ & $\cdot, Y_{1}$ & $\%$ & & \\
\hline 1. & $r$ & $\varepsilon$ & $r$ & 1 & . & . & العدد & \multirow{2}{*}{ 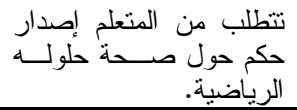 } & \multirow[t]{2}{*}{$r}$. \\
\hline$\cdot, r q$ & $\cdot, \varepsilon \varepsilon$ & זד, • & $\cdot, r$ & $\cdot, 11$ & . & . & $\%$ & & \\
\hline 1 & . & . & . & 1 & . & . & العدد & \multirow{2}{*}{ معلم حول من مصداته المتعلم مصادية إصدار } & \multirow[t]{2}{*}{ YI } \\
\hline$\cdot, \cdot r$ & . & . & . & $\cdot, 1 \wedge$ & . & . & $\%$ & & \\
\hline . & . & . & . & . & . & . & العدد & \multirow{2}{*}{ 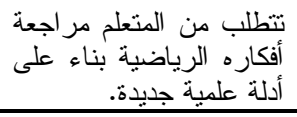 } & \multirow[t]{2}{*}{ rY } \\
\hline . & . & . & . & . & . & . & $\%$ & & \\
\hline . & . & . & . & . & . & . & العدد & \multirow{2}{*}{ تحثة للمساهمات الفردية إعطاء } & \multirow[t]{2}{*}{ rT } \\
\hline . & . & . & . & . & . & . & $\%$ & & \\
\hline$\Lambda$ & $r$ & r & $r$ & 1 & . & . & العدد & \multirow{2}{*}{ 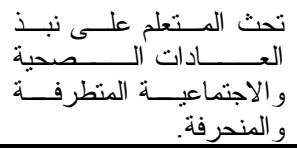 } & \multirow[t]{2}{*}{$r \varepsilon$} \\
\hline r & $\cdot, \varepsilon \varepsilon$ & • & $\cdot, \Gamma_{1}$ & $\cdot, 11$ & . & . & $\%$ & & \\
\hline 114 & rq & rT & rI & $r V$ & 7 & $r$ & العدد & \multirow{2}{*}{ 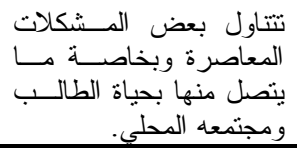 } & \multirow[t]{2}{*}{ ro } \\
\hline$r, r r$ & $\varepsilon, Y_{0}$ & $\varepsilon, .9$ & $r, r \leq$ & $\varepsilon, 90$ & $1, r \wedge$ & rT, & $\%$ & & \\
\hline 10 & $\varepsilon$ & $r$ & $r$ & 0 & 1 & . & العدد & \multirow{2}{*}{ 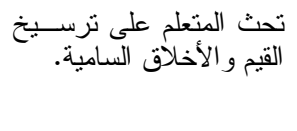 } & \multirow[t]{2}{*}{ rT } \\
\hline$\cdot, \varepsilon r$ & $\cdot, 09$ & $\cdot, \Sigma V$ & $\cdot, r)$ & . 94 & $\cdot, r)$ & & $\%$ & & \\
\hline
\end{tabular}




\begin{tabular}{|c|c|c|c|c|c|c|c|c|c|}
\hline المجموع & الصف & الخامس & الصف & الثف & الثاني & الصف & الفقرات & يتضمن المحتوي مناثط & م \\
\hline . & . & . & . & . & . & . & العدد & \multirow{2}{*}{ 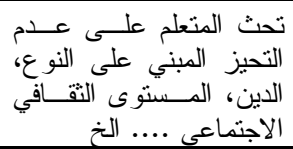 } & \multirow[t]{2}{*}{$T V$} \\
\hline . & . & . & . & . & . & . & $\%$ & & \\
\hline 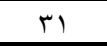 & $\varepsilon$ & 0 & 7 & $\Lambda$ & 7 & $r$ & العدد & \multirow{2}{*}{ 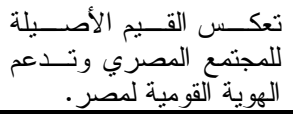 } & \multirow[t]{2}{*}{ rA } \\
\hline$\cdot, 9$. &., 09 & $\cdot, \vee \vee q$ & r, & $1, \leqslant V$ & $1, Y \wedge$ & $\cdot, \varepsilon r$ & $\%$ & & \\
\hline . &. & . &. & . & . & . & العدد & \multirow{2}{*}{ تلتث المتعلم على ممارسة. } & \multirow[t]{2}{*}{$r 9$} \\
\hline . & . & . & . & . & . & . & $\%$ & & \\
\hline . & . & . & . & . & . & . & العدد & \multirow{2}{*}{ 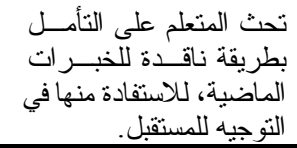 } & \multirow[t]{2}{*}{$r}$. \\
\hline . & . & . & · & . & . & . & $\%$ & & \\
\hline . & . & . & . & . & . & . & العدد & \multirow{2}{*}{ 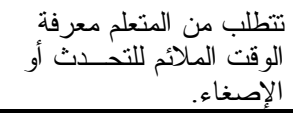 } & \multirow[t]{2}{*}{ ו } \\
\hline . & . & . & . & . & . & . & $\%$ & & \\
\hline . & . & . & . & . & . & . & العدد & \multirow{2}{*}{ 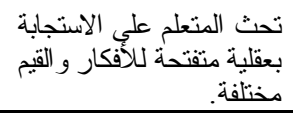 } & \multirow[t]{2}{*}{ rT } \\
\hline · & . & · & - & - & · & - & $\%$ & & \\
\hline . & . & . & . & . & . & . & العدد & \multirow{2}{*}{ 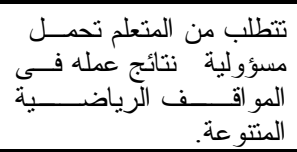 } & \multirow[t]{2}{*}{ זr } \\
\hline . & . & . & . & . & . & . & $\%$ & & \\
\hline rIV & 01 & or & rq & $\leq 9$ & 11 & $\Lambda$ & العدد & \multirow{2}{*}{\multicolumn{2}{|c|}{ لمجموع }} \\
\hline $7, Y V$ & $V, \varepsilon V$ & $\Lambda, 1 \wedge$ & $T, \cdot r$ & $\Lambda, q \mathrm{~V}$ & $\Gamma, \wedge \varepsilon$ & 1,77 & $\%$ & & \\
\hline
\end{tabular}

لدى تلامبذ المرحلة الابتدائيــة مــن خــلالمل

محتوى كتب الرياضبات المدرسية.

وتكشف نتائج التحليل عددًا من النقاط يمكن

$$
\text { تلخيص أبرزها فيما يلي: }
$$

- غياب تام لــبعض المهـــار ات الفرعيــة المندرجة تحث مهار ات الحياة الاجتماعية منل: وجود مناشط رياضية نشجع المتعلم على التحكم فى مشناعره عند التعامل فى مي المواقف الاجتماعية؛ ومر اعاة مــثاعر

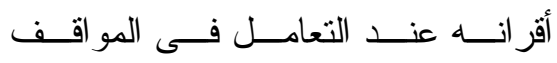
الاجتماعية؛ ومناقشتة الأفكار الرياضــية مع أقر انه داخل وخارج الفصل؛ وتحمل

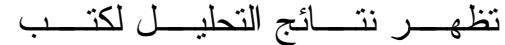

الرياضيات المدرسية فــي الــصفوف مــن الأول حتى السادس الابتدائي تحقق مهار ات القرن الحادي و العشرين فيما يتعلق بالمحور الثالث الخاص بمهار ات الحياة الاجتماعيــة

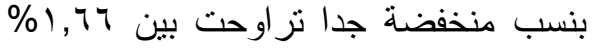

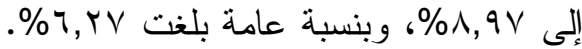
و هذا يعني عدم اهتمام تلك الكتب بتــضمين مو اقف رياضية تهدف إلى تتمية المهـــار ات الفرعية المندرجة تحــــت مهـــار ات الحيــاة الاجتماعية باعتبار ها و احدة مــن مهــار ات القرن الحادي و العثرين الواجــب تتميتهــــا 
أو الإصغاء، أو نوجه المتعلم نحو التكيف

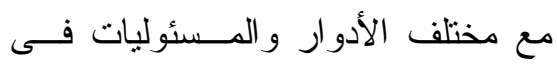

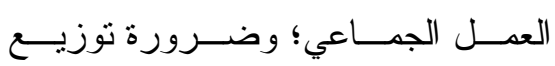
المسئوليات بين أفراد الجماعة؛ أو تتطلب

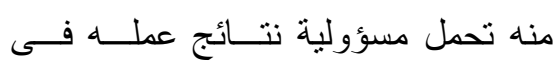

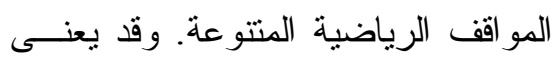
ذلك أن تلك المهار ات الفرعية - رغــم

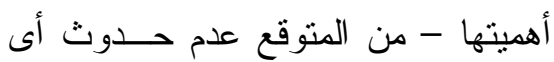

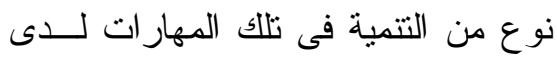
تلاميذ المرحلة الابتدائية لعدم مسرورهم بخبــر ات تربويـــة فــى مجــال تعلــيم

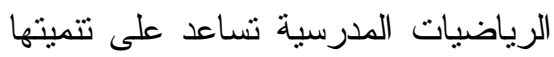

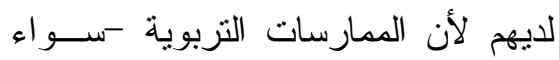

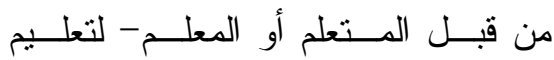
الرياضيات وتعلمها تتأثر بشكل كبير بما

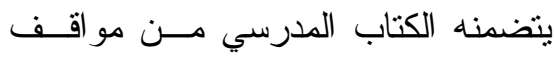

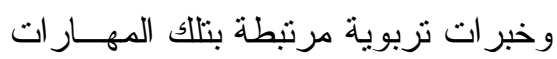
الفرعبة. وذذلك على الرغم من أن مقدمة بعض نلاك الكتب تشير الى دعوة المتعلم للعمل التعاوني مع مجموعة من زملائه

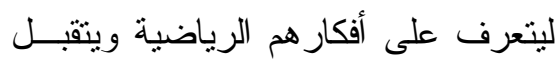

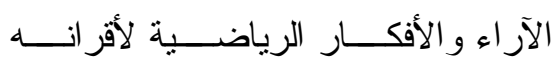

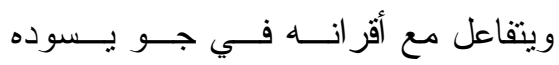
الاحتر ام المتبادل.

- وجود اهتمام - بلرجة مقبولة - في كتب

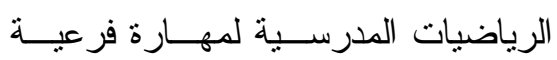
واحدة مندرجة تحــت مهــار ات الحيـاة
مسئولية قيامهم بأي مهـام رياضــية؛ وتقدير أهمية احتر ام مسئولية أقـــر انهم

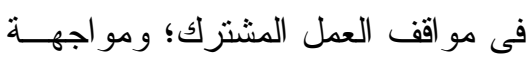
العقبات و الـــضغوط لتحقيــق النتـــائج

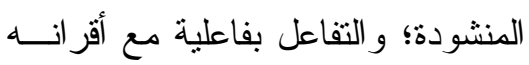
في جو من الاحتر ام؛ والاستفادة مسنـ

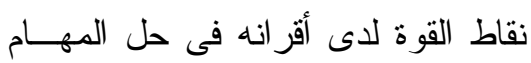

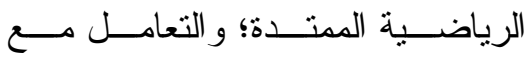
الأهداف و المهام و المدخلات المتعددة؛ وتقبل الآراء و الأفكار الرياضية لأقر انه

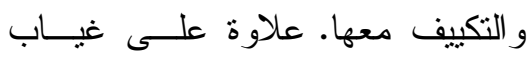
المناشط الرياضية التى تحث المـتعلم على إدارة وقت تعلمه عند التعامل مع

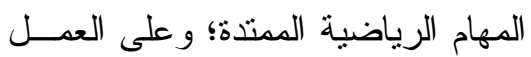
بشكل مستقل عند التعامل مـــع المهــام

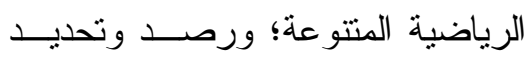

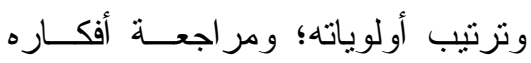

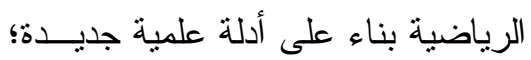
و إعطاء قيمة للمساهمات الفردية لكــل عضو في الفريق؛ وعدم التحيز المبني

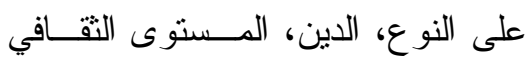
الاجتماعي .... الخ؛ وممارسة التوجيه الذاتي قدر الإمكان؛ و التأمل بطريقــــة ناقدة للخبر ات الماضية، للاستفادة منها في التوجيه للمستقبل؛ و الاستجابة بعقلية متقتحة للأفكار و القيم مختلفة. أو تتطلب من المتعلم معرفة الوقت الملائم للتحدث 
على سبيل المثــال لا الحـصر : تـشجع

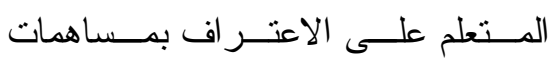

الرياضيات في الثقافات المنتوعة. و التي

اختفت في كتب الصفين الثانى و الثالـــثن

بينما تظهر بعض الكتب - فـى بــاقى

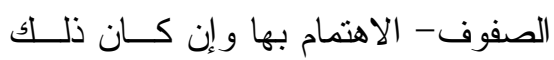

الاهتمام جاء بشكل منخفض جدا. ويمكن

أن يرجع ذلك إلى اختلاف السادة القائمين

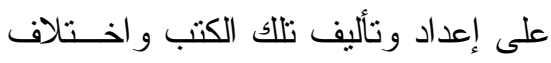

توجهاتهم الفكرية و التزبويـــة مدــــا أدى ولى

بطبيعة الحال إلى الاختلاف فى درجهـة اهتمامهم بتلك المهار ات الفرعية.

و استكمالا للإجابة عن السؤ ال الثــاني

من أسئلة البحث تم حساب تكرار كل مهــارة

فرعية من مهار ات المحور الر ابــع و النـسبة

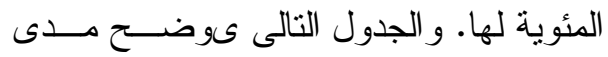

تو افر مهار ات التتور المعرفي و التكنولـــوجي

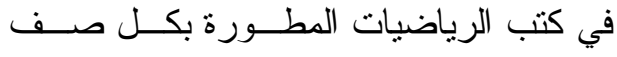

در اسي من صفوف المرحلة الابتدائيــة فــى
الاجتماعية والمنمثلة في وجود مناثط

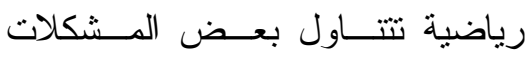

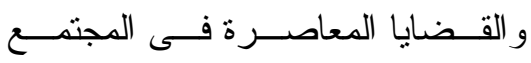

المصري منل البدانة و الادخار و الأمية

و السياحة وبخاصة ما يتصل منها بحياة

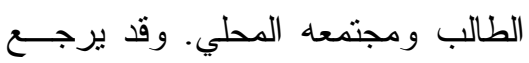

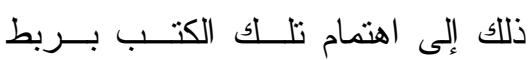

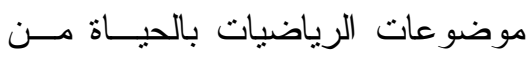

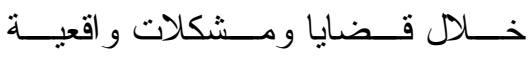

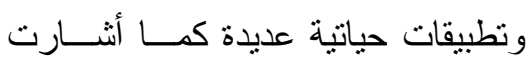

مقدمة بعض من تلاك الكتب لمحاولــــة

أثنعار المتعلم بقيمة الرياضيات و أهمية در استها كعلم نافع فى الحياة.

- تختلف نسب اهتمام كتب الرياضــيات

المدرسية في الصفوف من الأول حتى

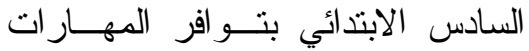

الفرعية المندرجة تحت مهار ات الحياة

الاجتماعية من كتاب إلى آخر : حيــث

نجد في بعض الكتب تختفي منها تماما

بعض تلأك المهار ات الفرعيــة (منهـــا 
جدول (†): درجة تو افر مهارات التتور المعرفي والتكنولوجي فى كتب الرياضيات المطورة بكل

\begin{tabular}{|c|c|c|c|c|c|c|c|c|c|}
\hline المجموع & الصفاد & الخفس & الصف & الصف & الثفاني & الصف & الفقرات & يتضمن المحتوى مناشط & p \\
\hline . & . & . & . & • & . & . & العدد & \multirow{2}{*}{ 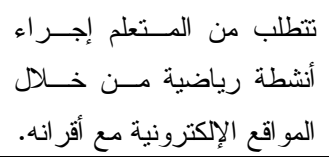 } & \multirow[t]{2}{*}{1} \\
\hline . & . & . & . & . & . & . & $\%$ & & \\
\hline 7 & r & r & r & . & . & . & العدد & \multirow{2}{*}{ 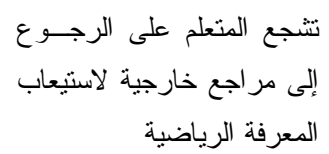 } & \multirow[t]{2}{*}{$r$} \\
\hline$\cdot, I V$ & $\cdot, r 9$ & $\cdot, r$ & $\cdot, r$, & . & . & . & $\%$ & & \\
\hline • & • & · & • & · & · & - & العدد & \multirow{2}{*}{ 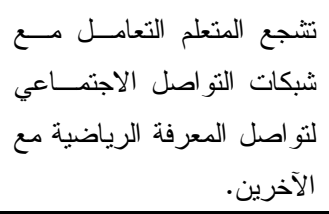 } & \multirow[t]{2}{*}{$r$} \\
\hline . & . & . & . & . & . & . & $\%$ & & \\
\hline . & . & . & . & . & . & . & العدد & \multirow{2}{*}{ 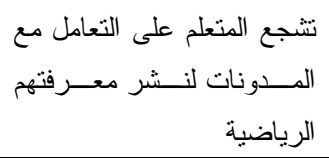 } & \multirow[t]{2}{*}{$\varepsilon$} \\
\hline . & . & . & . & . & . & . & $\%$ & & \\
\hline 1 & . & 1 & . & . & . & . & العدد & \multirow{2}{*}{ المكتع المتعلم على التعامل مع الرقمية للبحث عـن الرعن } & \multirow[t]{2}{*}{ 。 } \\
\hline$\cdot, r_{q}$ & . & .17 & & . & . & . & $\%$ & & \\
\hline 1 & 1 & . & . & . & . & . & العدد & \multirow{2}{*}{ 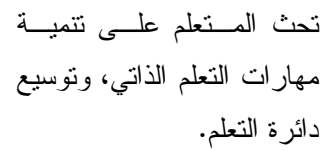 } & \multirow[t]{2}{*}{7} \\
\hline$\cdot, r q$ & $\cdot, 10$ & . & . & . & . & . & $\%$ & & \\
\hline - & - & · & - & - & - & . & العدد & \multirow{2}{*}{ 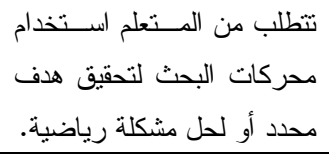 } & \multirow[t]{2}{*}{ V } \\
\hline . & . & . & . & . & - & . & $\%$ & & \\
\hline $1 \varepsilon$ & 7 & 7 & r & - & · & . & العدد & \multirow{2}{*}{ 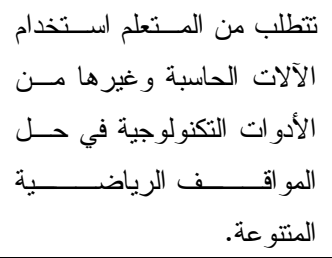 } & \multirow[t]{2}{*}{$\wedge$} \\
\hline$\cdot, \varepsilon$ • & $\cdot, \wedge \wedge$ & $\cdot, 9 \leq$ & $\cdot, M_{1}$ & . & . & . & $\%$ & & \\
\hline $1 \varepsilon$ & $\wedge$ & $\varepsilon$ & r & - & - & - & العدد & تتطلب من المــتعلم توظيــف & 9 \\
\hline
\end{tabular}




\begin{tabular}{|c|c|c|c|c|c|c|c|c|c|}
\hline المجموع & الصفادس & الخف الصف & الصف & الثفالث & الثاني & الصف الأول & الفقرات & يتضمن المحتوى مناشط & م \\
\hline$\cdot, \varepsilon$. & $1,1 \mathrm{~V}$ & זד, • & $\cdot, r)$ & . & . & . & $\%$ & إنجاز مهام رياضية محيبوترية للمساعدة فى & \\
\hline$\varepsilon$ & r & r & . & . & . & . & العدد & \multirow{2}{*}{ 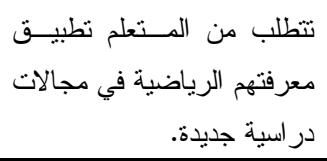 } & \multirow[t]{2}{*}{1.} \\
\hline •, IT & $\cdot, r q$ & $\cdot, r)$ & . & . & . & . & $\%$ & & \\
\hline 11 & v & r & r & r & $r$ & 1 & العدد & \multirow{2}{*}{ 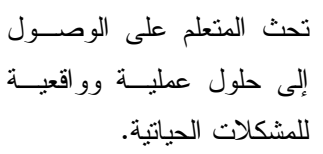 } & \multirow[t]{2}{*}{11} \\
\hline .,Or & $1, \cdot r$ & $\cdot, \leqslant \vee$ & $\cdot, \leqslant 7$ & •,rV & • & $\cdot, Y_{1}$ & $\%$ & & \\
\hline . & . & . & . & . & . & . & العدد & \multirow{2}{*}{ 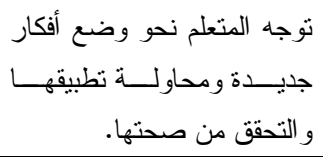 } & \multirow[t]{2}{*}{ Ir } \\
\hline . & . & . & . & . & . & . & $\%$ & & \\
\hline . & . & · & . & . & . & - & العدد & \multirow{2}{*}{ 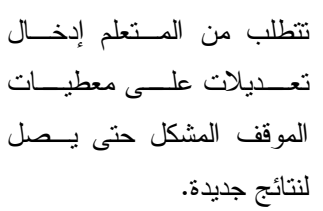 } & \multirow[t]{2}{*}{ r } \\
\hline . & . & . & . & . & . & . & $\%$ & & \\
\hline . & . & . & . & . & . & . & العدد & \multirow{2}{*}{ 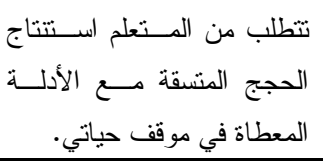 } & \multirow[t]{2}{*}{$1 \leq$} \\
\hline . & . & . & . & . & . & . & $\%$ & & \\
\hline . & . & . & . & . & . & . & العدد & \multirow{2}{*}{ 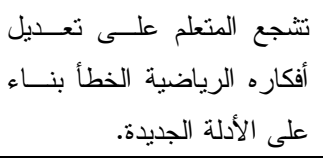 } & \multirow[t]{2}{*}{10} \\
\hline . & . & . & . & . & . & . & $\%$ & & \\
\hline . & . & . & . & . & . & . & العدد & \multirow{2}{*}{ 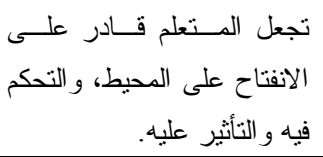 } & \multirow[t]{2}{*}{17} \\
\hline . & . & . & . & . & • & . & $\%$ & & \\
\hline 9 & 1 & r & r & $r$ & . & 1 & العدد & \multirow{2}{*}{ 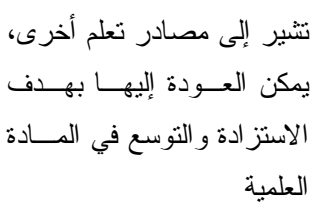 } & \multirow[t]{2}{*}{ IV } \\
\hline • & $\cdot, 10$ & • & $\cdot, \leqslant 7$ & •, rV & . & $\cdot, Y_{1}$ & $\%$ & & \\
\hline 17 & $\varepsilon$ & $\varepsilon$ & $r$ & r & 1 & r & العدد & \multirow{2}{*}{ 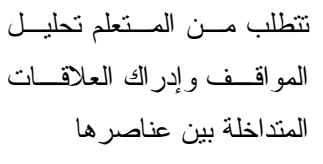 } & \multirow[t]{2}{*}{11} \\
\hline$\cdot, \leqslant 7$ &., 09 & אד, • & $\cdot, \leqslant 7$ & $\cdot, r V$ & $\cdot, r_{1}$ & $\cdot, \varepsilon r$ & $\%$ & & \\
\hline
\end{tabular}




\begin{tabular}{|c|c|c|c|c|c|c|c|c|c|}
\hline المجموع & الصفاد الص & الخف الصف & الصف & الثالث & الثاني & الصف & الفقر ات & يتضمن المحتوى مناثط & م \\
\hline 7 & r & $r$ & · & . & 1 & . & العدد & \multirow{2}{*}{ 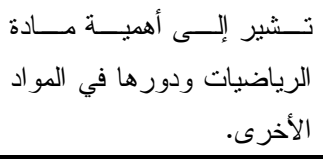 } & \multirow[t]{2}{*}{19} \\
\hline$\cdot, I V$ & $\cdot, r q$ & $\cdot, \leqslant V$ & . & . & $\cdot, r_{1}$ & . & $\%$ & & \\
\hline 。 & 1 & r & . & . & 1 & 1 & العدد & \multirow{2}{*}{ تشجع المتعلم على تقدير دور } & \multirow[t]{2}{*}{$r}$. \\
\hline$\cdot, 1 \varepsilon$ & $\cdot, 10$ & • & . & . & $\cdot, r_{1}$ & $\cdot, r_{1}$ & $\%$ & & \\
\hline . & . & . & . & . & . & . & العدد & \multirow{2}{*}{ خدمة المجتمع. دور الرياضيات فـي } & \multirow[t]{2}{*}{ r) } \\
\hline . & · & • & . & . & · & . & $\%$ & & \\
\hline$\wedge$ & 。 & r & . & . & . & . & العدد & \multirow{2}{*}{ تبعضط العلوم الأخرى. ترى الرياضـــــات } & \multirow[t]{2}{*}{ rr } \\
\hline ש & $\cdot, \mathrm{Vr}$ & $\cdot, \sum \vee$ & · & · & · & . & $\%$ & & \\
\hline$\varepsilon$ & 1 & 1 & . & r & . & . & العدد & \multirow{2}{*}{ تولعي المتعلم ببعض قـــايا. } & \multirow[t]{2}{*}{ rr } \\
\hline$\cdot, 1 r$ & $\cdot, 10$ & .17 & . & $\cdot, r V$ & . & . & $\%$ & & \\
\hline . & . & . & . & . & . & . & العدد & \multirow{2}{*}{ 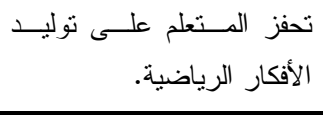 } & \multirow[t]{2}{*}{$r \varepsilon$} \\
\hline . & . & . & . & . & · & . & $\%$ & & \\
\hline . & . & . & . & . & . & . & العدد & \multirow{2}{*}{ 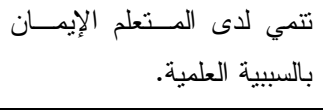 } & \multirow[t]{2}{*}{ ro } \\
\hline . & . & . & . & . & . & . & $\%$ & & \\
\hline 1.7 & $\varepsilon$. & זr & 10 & $\wedge$ & 0 & 0 & العدد & \multirow{2}{*}{ المجموع } & \\
\hline$r, \cdot T$ & $0, \wedge 7$ & 0,19 & $r, r$, & $1, \leqslant V$ & $1, \cdot v$ & $1, \cdot \varepsilon$ & $\%$ & & \\
\hline
\end{tabular}

تظهر نتائج التحليل لكتب الرياضيات مهــار ات التتـور المعرفــي و التكنولــوجي المدرسية في الـصفوف مــن الأول حتهى باعتبار ها واحدة من مهار ات القرن الحسادي

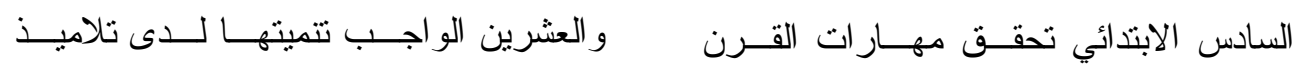

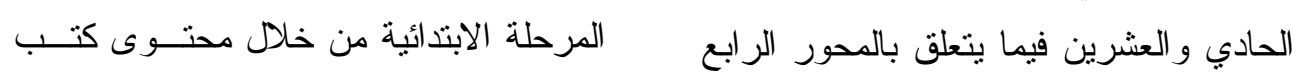

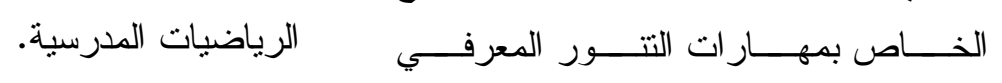

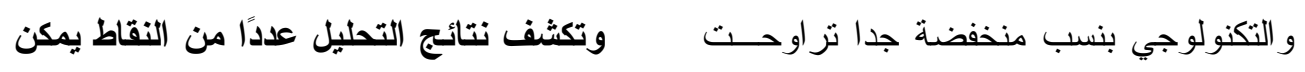

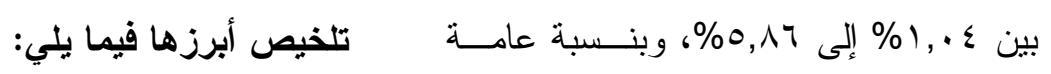

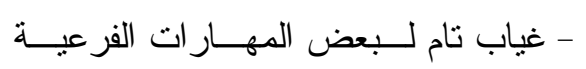

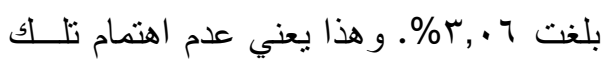

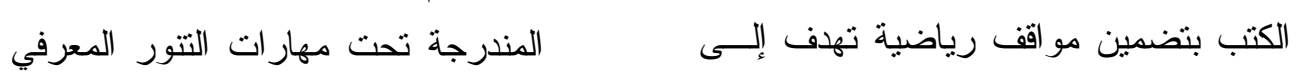

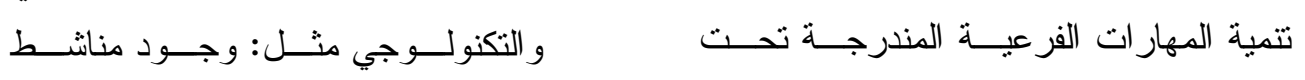


الرياضــبات المدرســي مـن مو اقـــ وخبر ات تزبوية. - وجود اهتمام - بدرجة ضــعيفة - فــي

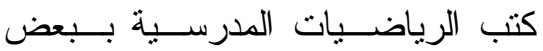

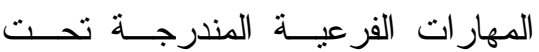
مهارات التتور المعرفي و التكنولـــوجي متل : وجود مناشط رياضية تحث المتعلم على الوصول إلى حلول عملية وواقعية للمشكلات الحياتية؛ وتتطلب منه تحليـلـل المو اقف و إدرالك العلاقات المتداخلة بين عناصر ها؛ و اســتخدام الآلات الحاسـبة و غير ها من الأدوات التكنولوجية في حل

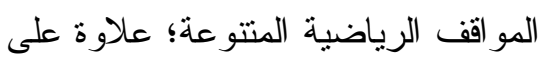

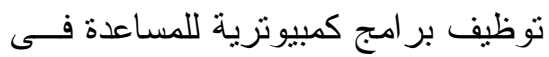
انجاز مهام رياضية محددة. وقد يعسزى لرئ ذلك الاهتمام الــضعيف بتتميــة تلـــك المهار ات لدى الطلاب إلى وجود مو اقف ومشكلات حياتية فى محتوى تلاك الكتب بدرجة معقولة كما نم الاشارة اليها فـى

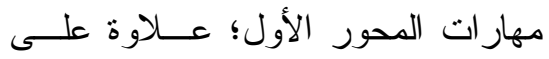
اهتمامها بتضمين تلك المواقف الواقعية بعض السقالات التعليمية التى من شأنها

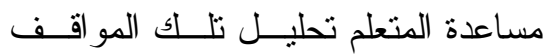
و إدر الك العلاقات المتضنة فيها؛ كمــا

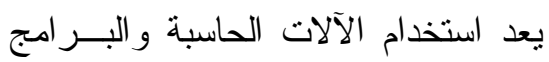
الكمبيوترية هدف من أهــداف منــاهج الرياضيات فى المرحلة الابتدائية؛ وأحد
رياضية تتطلب من المتعلم إجر اء أنشطة رياضية من خلال المواقع الإكترونيـــة

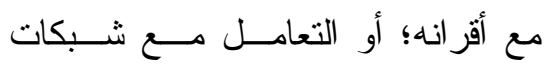
التواصل الاجتماعي لتواصل المعرفـــة

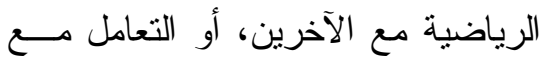

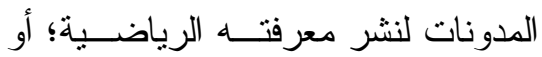

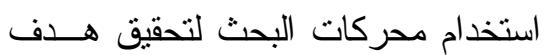
محدد أو لحل مشكلة رياضية؛ أو إدخال تعديلات على معطيات الموقف المشكل حتى يصل لنتائج جديــدة، أو اســنتئاج

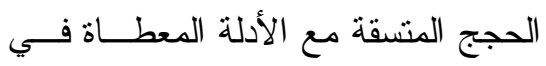
موقف حياتي؛ أو تعديل أفكاره الرياضية

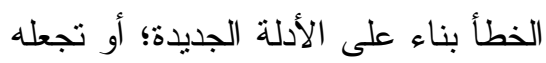

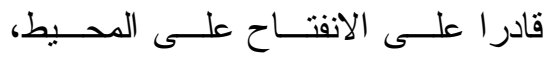

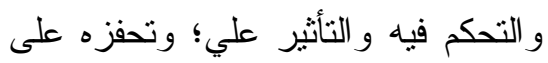

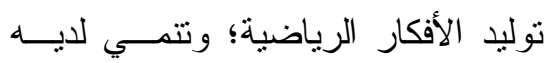

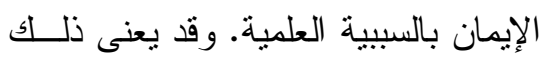

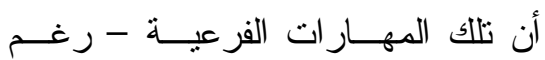
أهميتها - من المتوقع ألا يـتـم تتميتهــــا

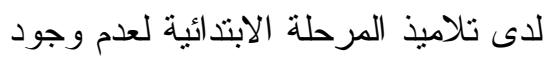

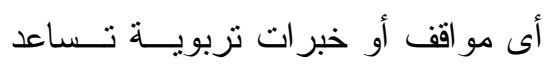

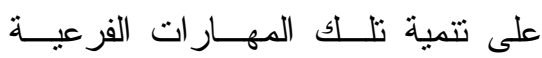
المندرجة تحت مهارات التتور المعرفي

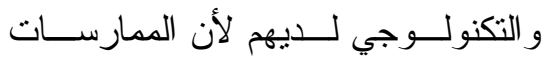
التزبوية لتعليم الرياضيات وتعلمها تعـد

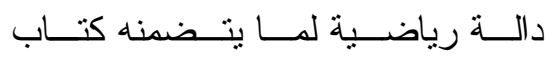




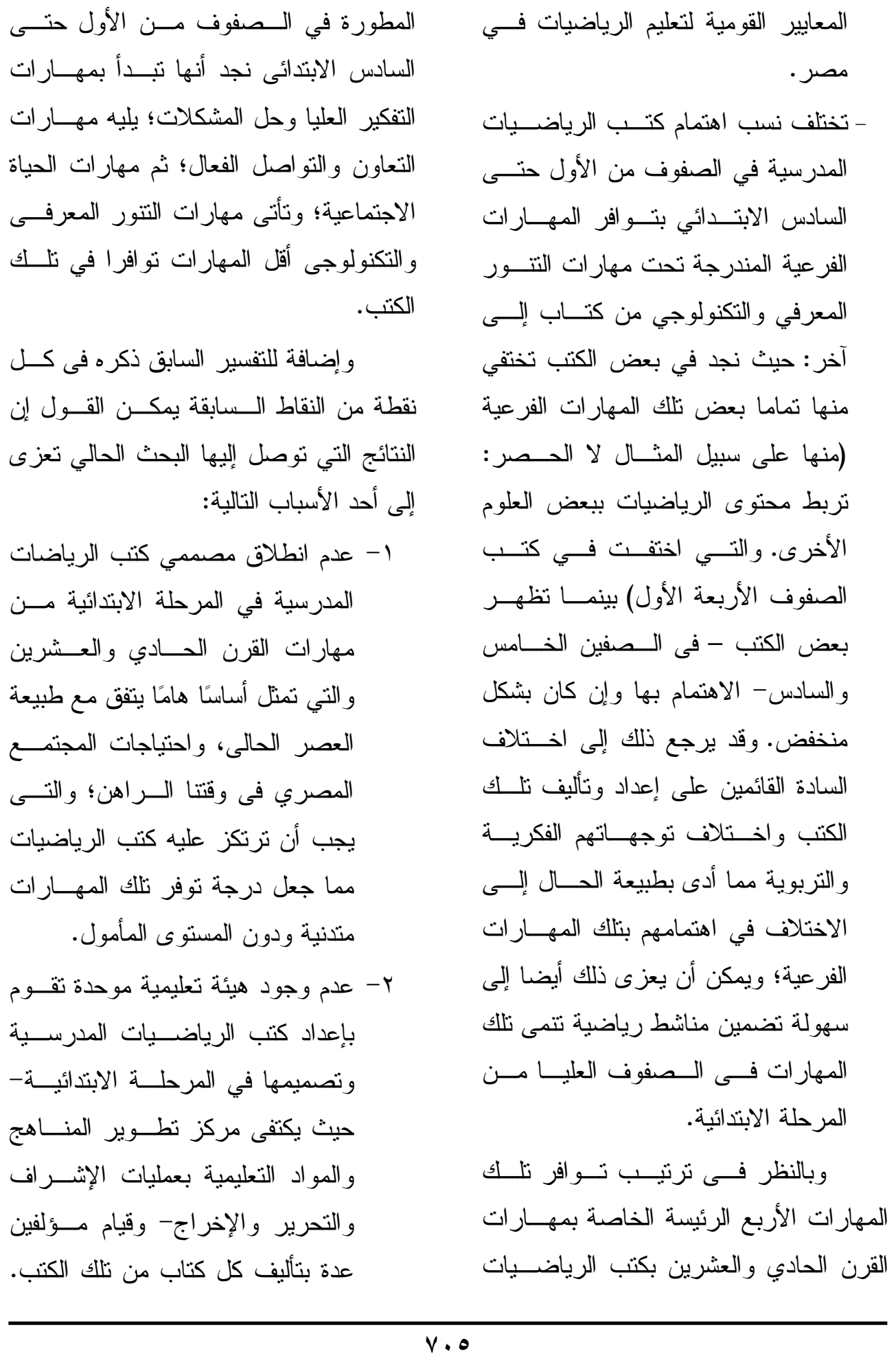




$$
\begin{aligned}
& \text { تشجع المتعلم على الجر أة على تحمل }
\end{aligned}
$$

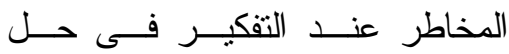

$$
\begin{aligned}
& \text { المــشكلات الرياضــــية و الحياتيــــة } \\
& \text { و التفكير في حلول مبتكرة لها؛ و التأمل وله }
\end{aligned}
$$

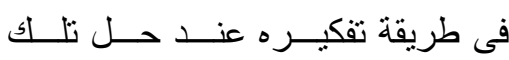

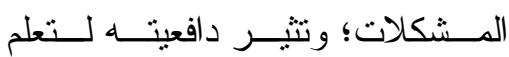

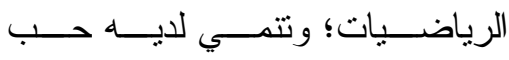

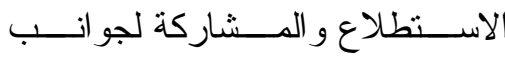

$$
\begin{aligned}
& \text { المعرفة الرياضية. }
\end{aligned}
$$

النتائج المتعلقة بالإجابة عن السؤال الثالث من أسئلة البحث والذي ينص على: ما المقترحات التى يمكن تقديمها لعلاج أوجه

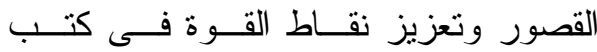
الرياضيات المطورة بالمرحلة الابتدائية فـى مصر فى ضوء منظومة مهــار ات القــرن

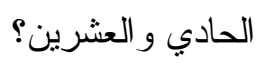

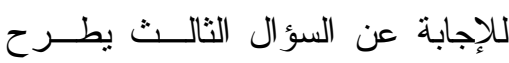
الباحث مجموعة من المقترحات و الإجر اءات

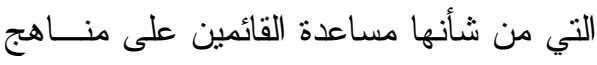
الرياضيات المدرسية في المرحلة الابتدائيــة في علاج أوجه القصور وتعزيز نقاط القــوة

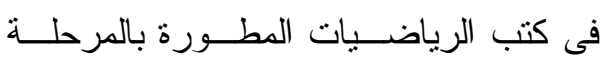
الابتدائية بمصر فى ضوء منظومة مهار ات

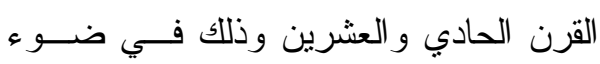
نتائج التحليل لمحتوى تللك الكتب التي توصل ودل إليها البحث الحالي التي تــم عرضـــها مـنـ خلال الإجابة عن السؤال الثاني من أســـئلة
مما يعنى عدم وجود رؤية و اضــحة وشاملة وموحدة لدى هؤلاء المؤلفين

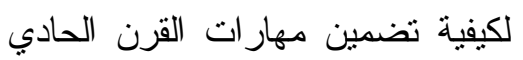

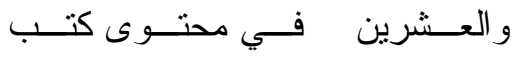
الرياضيات بالمرحلة الابتدائية. r- عدم إثنر الك المتخصصين في المـــواد

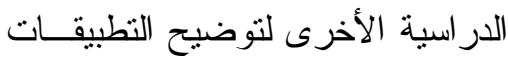

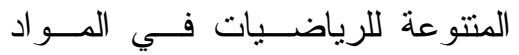
الار اسية الأخرى و النقاط البينية بـين لمبن

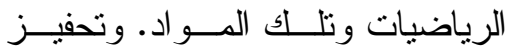
المتعلم على عمل نماذج رياضية لحل المشكلات الحياتية؛ وتطبيق معرفتــــ الرياضية في مجالات در اسية جديدة. ـ - عدم إثر الك المتخصصين فى الثقنيات

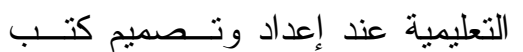
الرياضات المدرسية للمسساعدة فـى إنى توظيف الأدوات التكنولوجية المتتوعة فى عملية تعليم الرياضيات وتعلمهــا؛

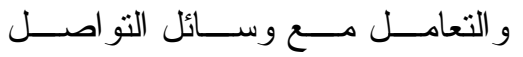
الاجتماعي المتتوعة لزيادة مسستوى ولن

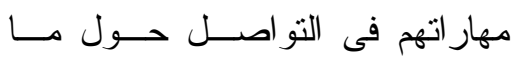
يقومون بدر استه من موضو عات فـى لى

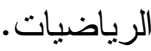
0- عدم إنشر الك المتخصصين فـي علـم النفس التعليمي و المعرفي عند إعــداد وتصميم كتب الرياضــات المدرســية للمساعدة فى تصميم مو اقف تعليميـــة 
غير كافي لتتمية مهار ات القرن الحادى و العشرين. حيث لا يمكن تتمية مهار ات بهات

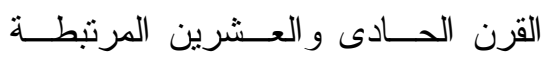

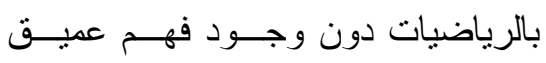
و إتقان لجوانــب المعرفــة الرياضـــية المختلفة التى تعد منطلب سابق للــتمكن من تلك المهار ات.

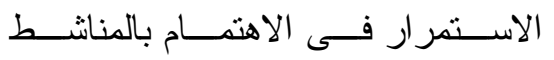

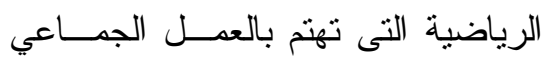

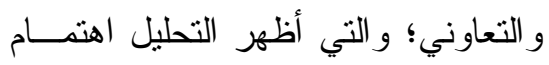

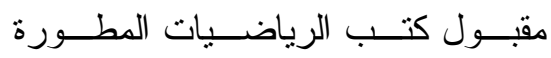
بالمرحلة الابتدائية بهـصر بهــا، مــع

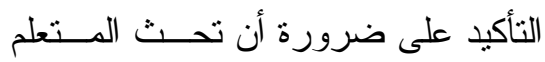
على إعطاء قيمة للمساهمات الفردية لكل

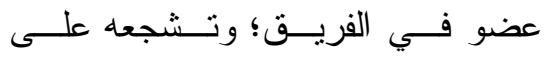
الاستفادة من نقاط القوة لدى أقر انه فــى ولى

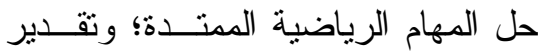

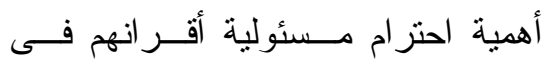

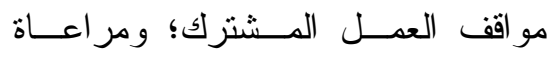

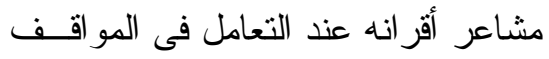
الاجتماعية؛ وتوجه المتعلم نحو التكيف

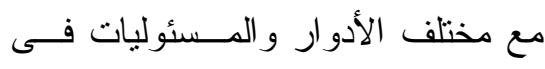
العمل الجماعي. لأنها تعد الطريق الذى لى لادي

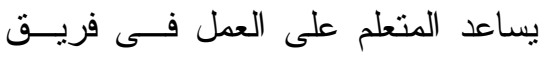

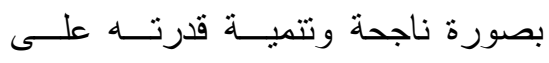

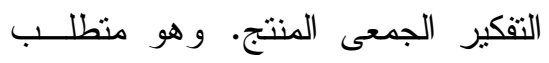
رئيس فى عصرنا الحالي لإعداد مــتعلم
البحث. ويمكن تحديد أهم تلــــ المقترحــات و الإجر اءات من خلال النقاط النالية: • مر اعاة المهار ات الغائبة في كل مهـارة رئيسة من مهــار ات القــرن الحــادي و العشرين في كتب الرياضيات المدرسية

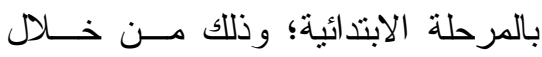
إدر اج مناشط رياضية متتوعة تـساعد على تتمية تلك المهار ات لدى المتعلمين. الوضع في الاعتبار عند بناء وتــصميم مناهج الرياضيات فى المرحلة الابتدائية

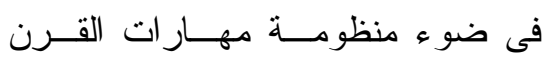
الحادي و العشرين أن تلك المهارات يتم

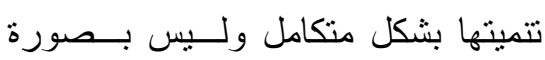

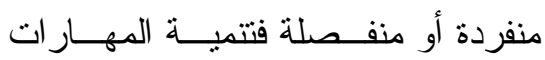

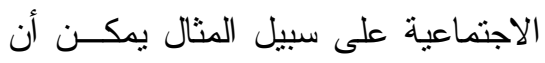

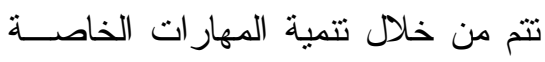

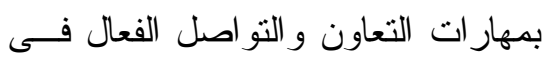
إطار مناثط رياضية تتمـى مهـــار ات

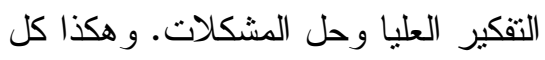

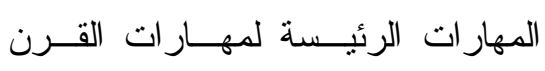
الحادي و العشرين.

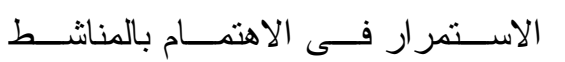

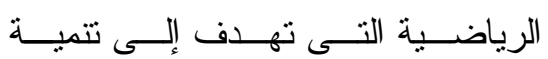

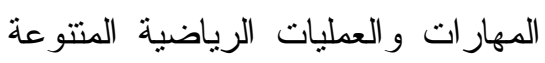

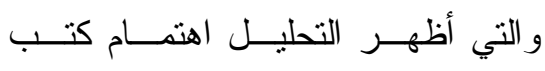
الرياضيات المطورة بالمرحلة الابتدائية

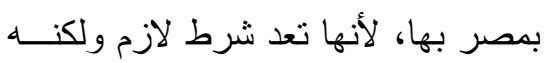


صف من صفوف المرحلـــة الابتدائيـــة وفى كل فصل در اســي أيــضـا، حيـــث

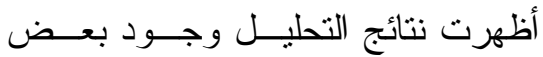
الاهتمام الضعيف بتلك المهــار ات فـى بعض الصفوف وغيابهـــا تمامـــا فــى صفوف أخرى. مما يعنى عدم التـــوازن

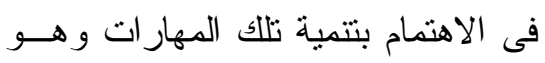
ضرورة لإحداث الاستمرارية فى تتمية مهارات القرن الحادى والعثرين طوال المرحلة الابتذائية. الاهنمام بالمناشط الرياضية فــى أطــر قيمية لتتمية القيم المجتمعيـــة المــصرية الأصيلة و الأخلاق السامبة؛ ونبذ العادات

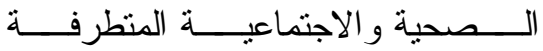
و المنحرفة؛ و التى تخلو من أنماط التحيز المبنية على النوع، الــدين، المــستوى التقافي والاجتماعي .... الـــخ؛ ودعـــ الهوية القومية لمصر حيث إنه لا يوجد مجال لتعزيز الهوية الوطنية أكثر مـن المناهج المدرسية. التركيز على المناشط الرياضــية التـى تعكس دور العلماء العرب و المــصريين فى تطور الرياضــيات فـي الثقافــات المختلفة؛ مما يزيد من تقــدير وتثـــين المتعلمين لدور علماء الرياضيات فـى تحسين وتطـــوير الحيــاة مــن جميــع

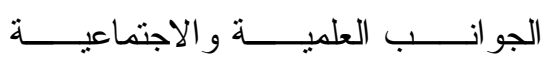

متكيف مع عصره وقادر على إحــداث التغيير ات المطلوبة لتطوير مجتمعه. التزر ابط الوثيــق بــين محتــوى كتــب

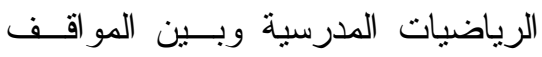
و المشكلات الحياتية من ناحية؛ وبينهــا وبين المواد الدر اســية الأخــرى التـى ولى يدرسها الطالب فيى المرحلـــة الابتدائيـــة من ناحية أخري، مع مر اعاة الاســتفادة

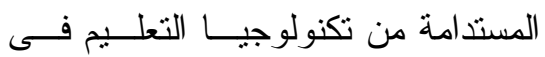

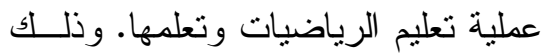
من خلال تتوع وشمولية المناشط التـى تزبط الرياضيات بفاعلية مــع المـــواد الار اسية الأخرى فى سياقات مجتمعيــة ومو اقف و اقعية وحياتية باستخدام تقنيات التعليم.

التزكيز على إبراز دور المــتعلم فـى عملية تعليم الرياضيات وتعلمها؛ وتعظيم دوره ومشاركات كل طالب مع مر اعاة

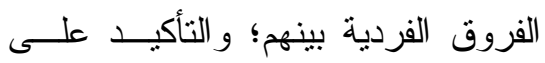
المناشط الرياضية التي تتطلب نوعا من التعاون مع أقر انه، وتحفيز هم على تقبل

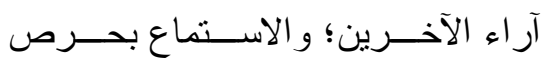
للآخرين وتفهم وجهات نظرهم المتعلقة بالمو اقف الرياضية و الحياتية.

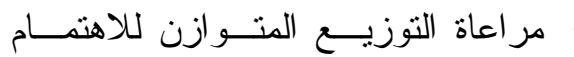
بالمهار ات الفرعية لكل مهارة رئيسة من مهار ات القرن الحادي و العشرين فى كل 


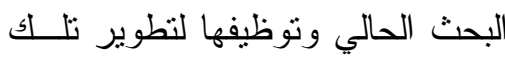
الكتب و الارتقاء بها. r- إعادة النظر في قضية تــأليف كتــاب الرياضـــات المدرســـي وتطــــــيره بالمرحلة الابتدائية - من خلال فــرق عمل من المتخصــصين فـى تعلــيم الرياضيات وتعلمها - في ضوء كـلـل من نتائج التى تـــم التوصــل إليهـــا؛ و المقترحات التى تم تقـــيمها لعــلاج أوجه القصور فى كتب الرياضــيات

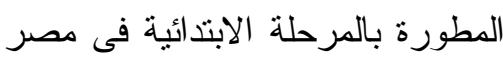

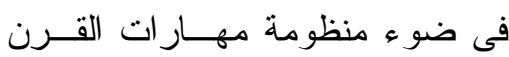

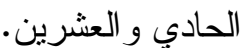
r- تنبى رؤية واضحة تستتد إلى تطوير

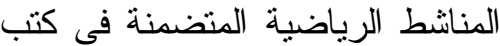

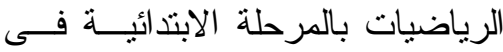

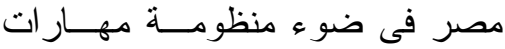
القرن الحادي و العشرين. و التركيـز فئز

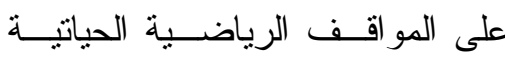
المرتبطة بحياة المتعلمين ومعاملاتهم

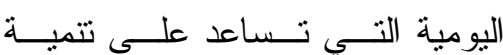
مهار اتهم الاجتماعية المتتوعة، وتفريد

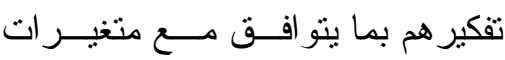
المو اقف الحياتية المتغيرة. ع - إثز اء محتــوى كتــب الرياضــيات بالمرحلة الابتدائية فى مصر بنطبيقات

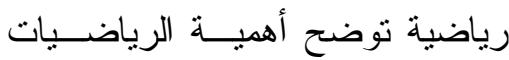
ودور ها فى تقدم العلوم الأخرى، وفي لهي لرياضي
و التكنولوجية. لأن ذلــــ بعـــــــــيل الوحيد لتوضيح ددى التعــاظم للـدور

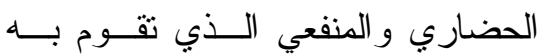

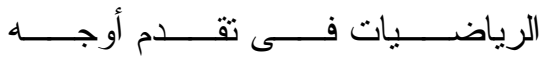

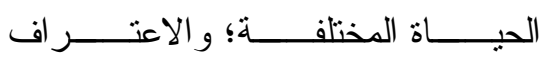
بمساهمات الرياضيات عبــر الثقافــات

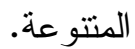

الحــرص علــى المناثتـــ الرياضــية التى تتجع المتعلهـين علـى التفكيـر المسـتقل، وتتميــة مهـــار ات التفكيــر

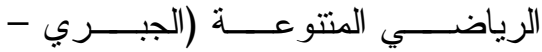
الهندسي- الدالي- الإحصائي- ...الخ)،

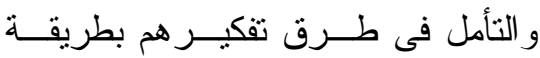

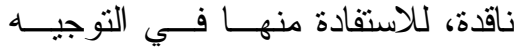
للمستقبل؛ و الاستجابة بعقليــة متفتحــــة لأفكار وقيم مختلفة. حيث أظهرت نتائج التحليل وجود اهتمام قليل بتلك المهارات وتطبيقها فى حالات جديـدة ومو اقـف متتو عة.

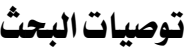

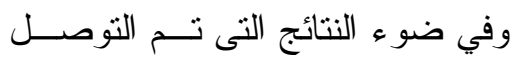

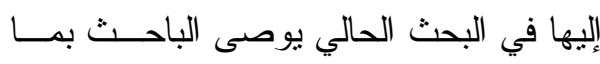
يلي: 1- تطوير بطاقة تقييم كتب الرياضــيات المطورة بالمرحلة الابتدائية فى مصر لفرئر

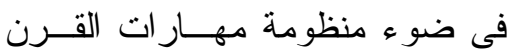

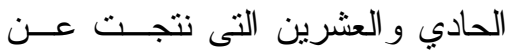


مهار ات القرن الحادي و العشرين فـى تتمية متغير ات منل البر اعة الرياضية

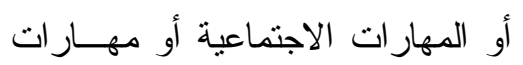

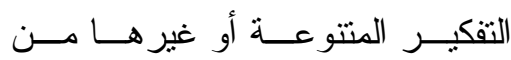

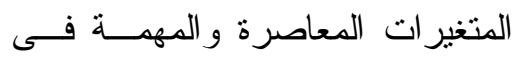
مجال تعليم الرياضيات وتعلمها.

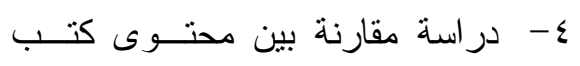

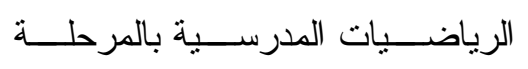

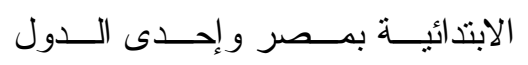

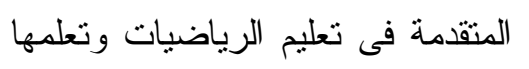

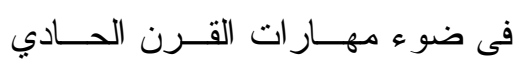

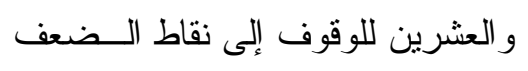

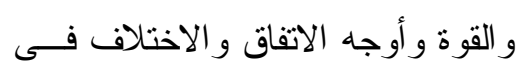
مناهج الرياضيات.

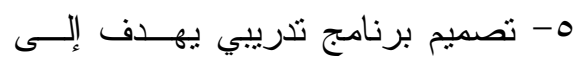

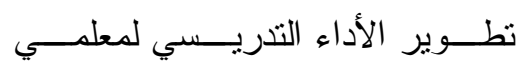

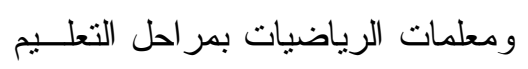
المختلفة بما يتو افق ويساعد فى تتمية مهار ات القرن الحادي و العشرين لدى لئ ولئ طلابهم.

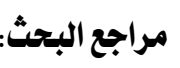
أولأ المراجع العربية

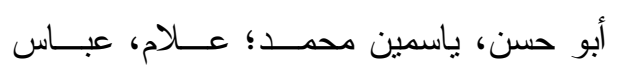

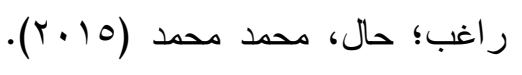

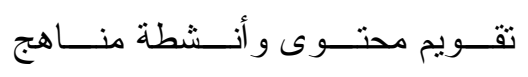

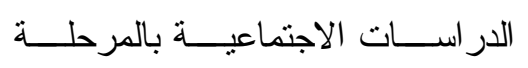

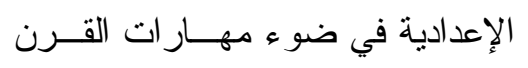
الحادي و العشرين. مجلة كلية التربية
تيسير المعاملات الحياتيـــة اليوميـــة؛ وكيفية توظيفهـا لفهـم المـشكلات و القضايا عبر الثقافات المختلفة. 0- اعتماد محتــوى كت بـ الرياضــيات

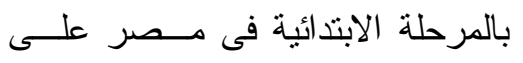
توظيف تكنولوجيا التعلــيم بأنتــكالها

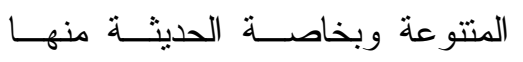

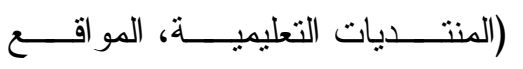

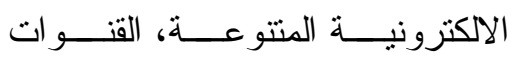
التعليمية، الايميل، ... إلخ) فى عملية تعليم الرياضيات وتعلمها وتقويمها.

\section{مقتزحات البحث}

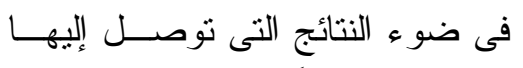

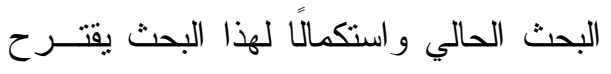
الباحث ما يلي: 1- توسيع مجال البحث، ليثمل إجــر اء

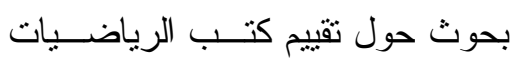
المدرسية بمصر فى مر احل دراسـية إسية

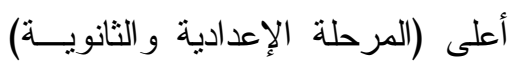

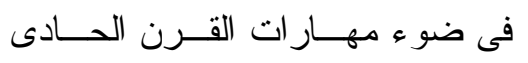
و العشرين.

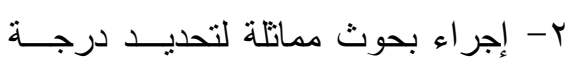

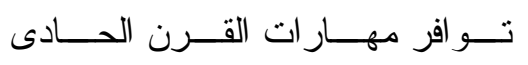
و العثرين فى كتب المو اد الدراســية

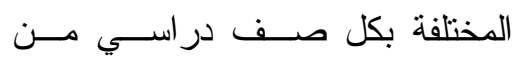

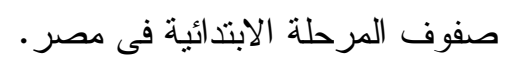

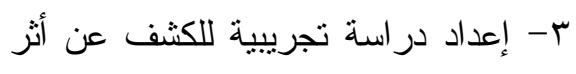
منهج للرياضيات يتم إعداده فى ضوء دركة 
- جامعة بورسعبب، ع 1) 1ا، يونيــو،

$. r \leqslant 0-Y q V$

الحمامي، إيمان جمال محمد (10 • (Y). تقويم محتوى كتب الرياضيات الفلـسطنبية للصفوف (0- 1) في ضوء معـابير TIMSS منشورة. كلية التزبية، جامعة الأزهر بغزة. الخزيم، خالد محمد؛ و الغامدى، محمد فهــ كه

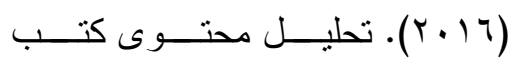
الرياضيات للصفوف العليا للمرحلــة الابتدائية بالمملكة العربية الـسعودية

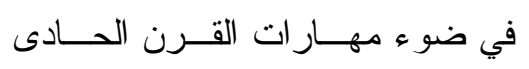
و العشرين. مجلة رسالة الثربية وعلم النفس، سه، يونيو، (1)-7.

ســعودى، عــلاء الـــدين حــسين إبــر اهيم

(T) القرن الحادي و العشرين لتتمية القر اءة الابتكارية واستقلالية التعلم لدى تلاميذ

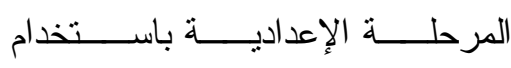
إســــر اتيجية إعــادة إنتـــاج الـــص. دراسات في المناهج وطرق التدربس،

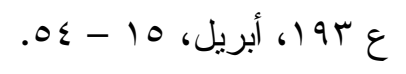

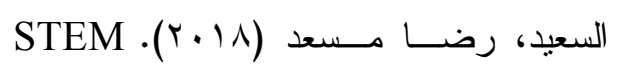

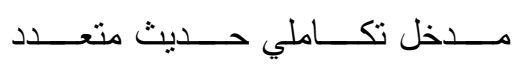
التخصصات للتميز الدر اسي ومهار ات القرن الحــادي و العـشرين. مجلـــة
- جامعة بورسعبل، ع 11ا، يونيــو، $.11 \leqslant V-11 r r$

أحمد، فائق فاضل؛ خلــف، ســناء حـسين

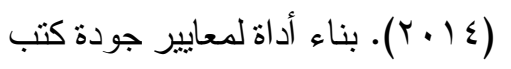
الرياضيات في المرحلـــة الابتدائيـــة.

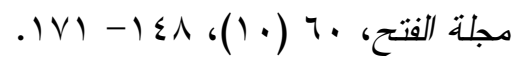
الباز ، مروة محمد (T/ • (Y). تطوير مسنهج العلوم للصف الثالث الإعـــدادي فــي

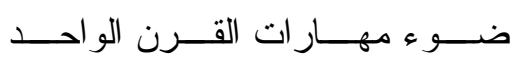
و العشرين. مجلة التربية العلمبـة، 7 $.4 M-191 .(17)$ بن سلمة، منــصور؛ و الحـــارثي، إيــر اهيم

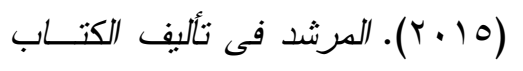
المدرسي ومو اصفاته، طء، الرياض: مكتبة التربية العربية لدول الخليج. التلينى، إير اهيم محمد نهرو (با • (ץ). تقويم

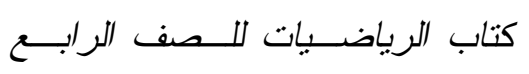
الأساسي في فلسطبن وفق متطلبـات TIMSS

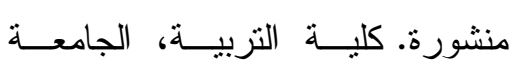
الإسـلامية. حسن، شيماء محمد علي (10 • ب). تطـــوير منهج الرياضيات للـصف الــسادس الإبتدائي في ضوء هـ مهــار ات القــرن الو احد و العشرين، مجلة كلية التربيــة 


$$
\begin{aligned}
& \text { الريـــاض: الإدارة العامـــة للتربيــــة } \\
& \text { تربويات الرياضيات، اب (Y)، } 7 \text { - }
\end{aligned}
$$

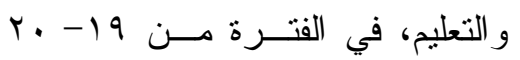

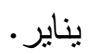

$$
\begin{aligned}
& \text { روفائيل، عصام؛ ويوسف، محمد (1. (Y). }
\end{aligned}
$$

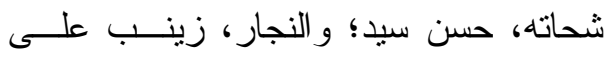

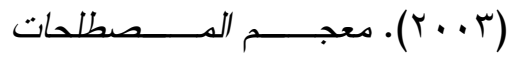

$$
\begin{aligned}
& \text { تعليم وتعلم الرياضيات فـــي القـــن } \\
& \text { الحادى و العشرين. القـــاهرة: مكتبــــة } \\
& \text { الأنجلو المصرية. } \\
& \text { الريحاوي، قمر محمد خير (· • • (Y). تقــويم } \\
& \text { التربوية والنفـسية. القـــاهرة: الـــار } \\
& \text { المصرية اللبنانية. } \\
& \text { شلبى، نوال محمد (ع ا • r). إطار مقتــرح }
\end{aligned}
$$

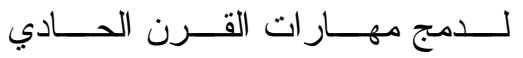

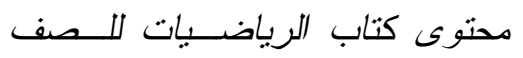

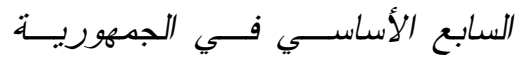

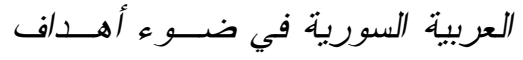

$$
\begin{aligned}
& \text { تدريب المادة. رسالة ماجستير غيــر }
\end{aligned}
$$

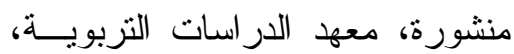

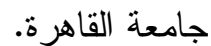

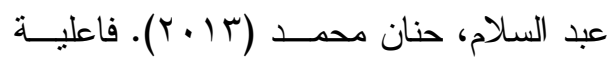

$$
\begin{aligned}
& \text { البرمجيات الاجتماعيــة فـــي تتميـــة } \\
& \text { الوعي الصحى وبعض مهار ات القرن } \\
& \text { الحادى و العشرين لدى طالبات جامعة ولعة لهات } \\
& \text { جاز ان. مجلة التربيــة العلمبــة، } 17 \\
& . r V \cdot-1996(r) \\
& \text { الغامدى، محمد فهم (10 (Y). تحليل محتوى } \\
& \text { كتب الرياضــيات للــصفوف العليـا } \\
& \text { للمرطلة الابتدائية في ضوء مهريسار ات } \\
& \text { القرن الحــادي والعـشرين. رســالة } \\
& \text { ماجستير غير منشورة، كلية العلــوم } \\
& \text { الاجتماعية، جامعة الإمام محمد بـن فيل } \\
& \text { و العشرين في مناهج العلوم بــالتعليم }
\end{aligned}
$$

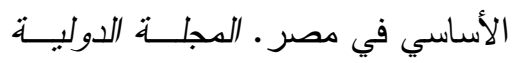

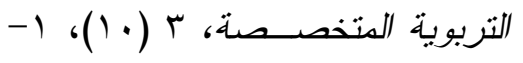

$$
\begin{aligned}
& \text { r } \\
& \text { شو اهين، خيـر ســليمان (10 بـ). التعلــبـ }
\end{aligned}
$$

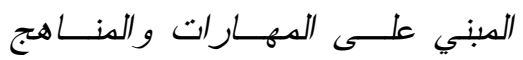

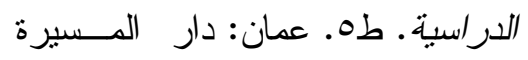

$$
\begin{aligned}
& \text { للنشر و التوزيع و الطباعة. }
\end{aligned}
$$

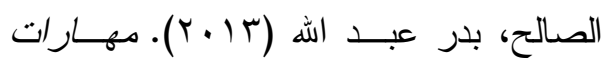

$$
\begin{aligned}
& \text { القرن الحادي و العشربي: التعلم للحياة } \\
& \text { فى زمننا. الرياض: منشور ات جامعة } \\
& \text { الملك سعود. }
\end{aligned}
$$

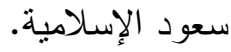


غير منشورة، كلية العلوم التربويــة، جامعة آل البيت، الأردن.

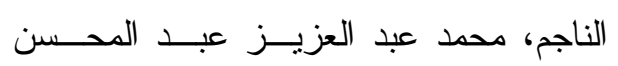

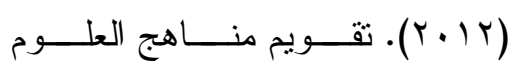

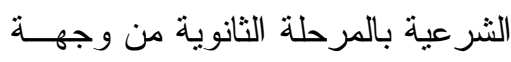

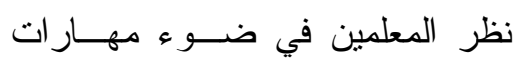

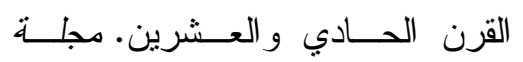

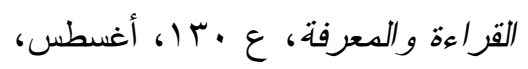

$$
\text { roT - r. } 7
$$

الهاشمي، عبد الرحمان؛ و عطية، محسن علي

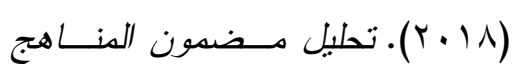

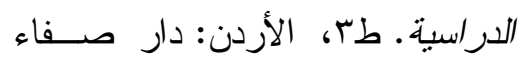

$$
\text { للنشر و التوزيع. }
$$

اللقانى، أحمد حسين، و الجمل، علــي أحمــد

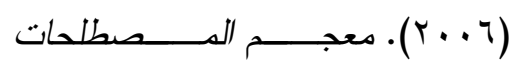

التربوية المعرفية في المناهج وطرق

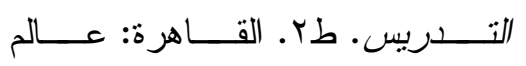

الكتب.

اليونسكو، منظمة الأمـــم المتحــدة للتزبيـــة

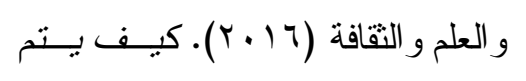

تعزيز المساواة بين الجنسبن بواسطة

الكتب المدرسية: دليل منهجي للفاعلين

و الفاعلات في مراحل إعداد الكتــاب

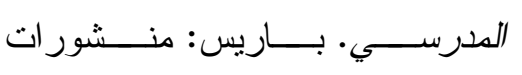

منظمة الأمم المتحدة للتربية و العلــــ لمن

$$
\text { و التقافة. }
$$

محمد، هبه محمد عبــد النظيــر (Y.IV).

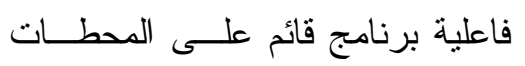

العلمية في تتمية التحصيل ومهــار ات بات

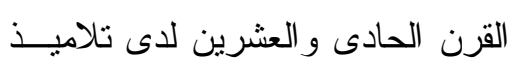

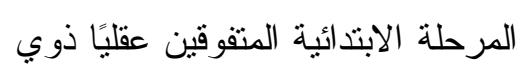

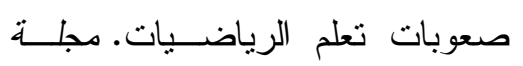

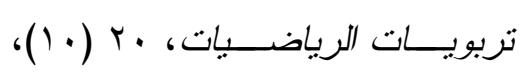

$.9)-\varepsilon \wedge$

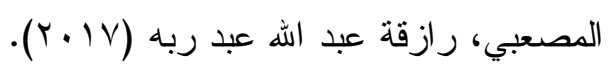

تقويم الأداء التذريسي لمعلمات العلوم

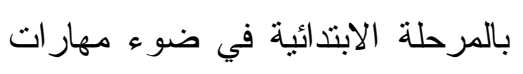

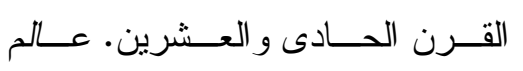

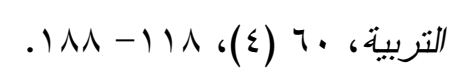

مرعي، نوفيق أحمد؛ و الحيلة، محمد محمود

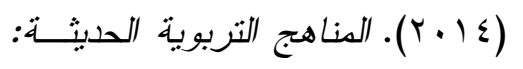

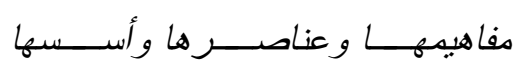

وعملياتها. طه. عمان: دار المـسيرة وعناه واهيرة

$$
\text { للنشر و التوزيع و الطباعة. }
$$

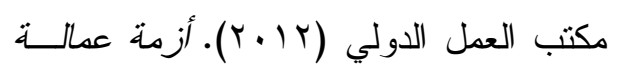

الشباب: حان وقت العدل. توصــيات

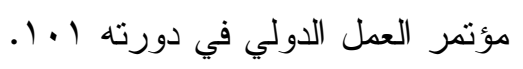

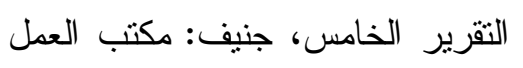

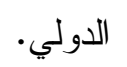

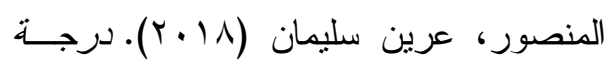

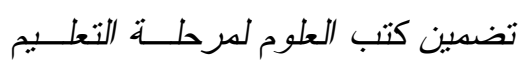

الأساسـي في الأردن لمهار ات القــــن لفرن

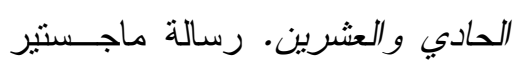


Marazano, R. \& Helfebower, A. (2012). Teaching \& Assessing $21^{\text {st }}$ century skills: The classroom strategies series. Bloomington, IN: Marazano Research.

North Central Regional Educational Laboratory (2003). EnGauge $21^{\text {st }}$ Century Skills: Helping Students Thrive in the Digital Age. Retrieved from: https://www.cwasd.k12.wi.us highsch1/newsfile1062 1.pdf

Organization for Economic Cooperation and Development. OECD (2008). $21^{\text {st }}$ Century Learning: Research, Innovation and Policy. Directions from recent OECD analyses. Retrieved from: http://www.oecd.org/site/edu ceri21st/ 40554299.pdf

Saavedra, A. \& Opfer, v. (2012). Teaching and Learning $21^{\text {st }}$ Century Skills: Lessons from the Learning Sciences. RAND Coroporation. Retrieved from: https://www.aare.edu.au/data/ publications/2012/Saavedra1 2.pdf

Schleicher, A. (2015), Schools for $21^{\text {st }}$ Century Learners: Strong Leaders, Confident Teachers, Innovative Approaches, International Summit on the

\section{ثانياً: المراجع الإجنبية}

Bellanca, J. \& Brandt, R. (2010). $21^{\text {st }} \quad$ Century Skills:

Rethinking How Students Learn: Leading Edge. Bloomington, IN: Solution Tree Press.

Binkley, M., Erstad, O., Hermna, J., Raizen, S., Ripley, M., Miller-Ricci, M., \& Rumble, M. (2012). Defining TwentyFirst Century Skills. In Griffin, P., Care, E., \& McGaw, B. Assessment and Teaching of $21^{\text {st }}$ Century Skills, Dordrecht, Springer. 17- 66.

Bybee, W. (2010). The Teaching of Science: $\quad 21^{\text {st }} \quad$ Century Perspectives, Virginia: National Science Teachers Association press.

Kay, K. (2010). Enriching Minds for the $21^{\text {st }}$ Century Foreword 21 $1^{\text {st }} \quad$ Century Skills: Why They Matter, What They Are, and How We Get There?. Retrieved from: http://www.innovationlabs.co $\mathrm{m} / \mathrm{plsd} /$ resources/kenkay.pdf

Kay, k., \& Greenhill, V. (2011). Twenty-First Century Students Need $21^{\text {st }}$ Century Skills. In G. Wan and D. Gut (eds.) Bringing Schools into the $21^{\text {st }}$ Century. New York: Springer. $41-65$. 
http://www.p21.org/storage/d ocuments/docs/

P21 framework 0816.pdf

The Partnership for $21^{\text {st }}$ Century Skills (2015b). Framework Definitions New. Retrieved from:

http://www.p21.org/storage/d ocuments/docs/

P21_Framework_Definitions New Logo 2015.pdf

Trilling, B. \& Fadel, C. (2009). $21^{\text {st }}$ Century skills Learning for life in our Times, San Francisco, CA: John Wiley \& Sons, Inc.

Wong, J., Tan, K., Lee, Y., Tan, T. (2017) Science Teacher Education for the Changing Landscape. In: Tan OS., Liu WC., Low EL. (eds) Teacher Education in the 21st Century. Springer, Singapore

Wright, E. \& Lee, M. (2014). Developing skills for youth in the $21^{\text {st }}$ Century: The role of ponentes of this view, Who have been termed "the $21^{\text {st }}$ Century skills movement". International Review of Education, 60 (2), 199-216. Retrieved from: http://www.jstor.org/stable/2 4636723
Teaching Profession, OECD Publishing, Paris. Retrieved from:

https://doi.org/10.1787/97892 64231191-en.

Stanley, E.; Waterman, M.; Wong, D.; Tan, H. (2011). Developing $21^{\text {st }} \quad$ Century Skills with Investigative Cases: Building Global Awareness and Informing Choices about Energy. Biology International, 50 (1), 95- 96.

Suto, I. (2013). $21^{\text {st }}$ Century skills: Ancient, ubiquitous, enigmatic?. Research Matters: A Cambridge Assessment Publication. Retrieved from: http://www.cambridgeassess ment.org.uk/Images/13043721st-century-skills-ancientubiquitous-enigmatic-.pdf

The Glossary of Education Reform (2016). 21 ${ }^{\text {st }}$ century skills. Created by the Great Schools Partnership. Retrieved from: https://www.edglossary.org/2 1 st -century-skills/

The Partnership for $21^{\text {st }}$ Century Skills (2015a). P21 Framework for $21^{\text {st }}$ Century Learning. Retrieved from: 